UNIVERSIDADE DE SÃO PAULO

FACULDADE DE FILOSOFIA, LETRAS E CIÊNCIAS HUMANAS

DEPARTAMENTO DE GEOGRAFIA

PROGRAMA DE PÓS-GRADUAÇÃO EM GEOGRAFIA HUMANA

\title{
GEOGRAFIA E RELAÇÕES RACIAIS: DESIGUALDADES \\ SÓCIO-ESPACIAIS EM PRETO E BRANCO
}

\begin{abstract}
Antonio Carlos Malachias
Dissertação apresentada ao Programa de PósGraduação em Geografia Humana do Departamento de Geografia da Faculdade de Filosofia Letras e Ciências Humanas da Universidade de São Paulo para a obtenção do título de Mestre.
\end{abstract}

Orientador: Prof. Dr. Francisco Capuano Scarlato

São Paulo 


\section{SUMÁRIO}

Resumo/Abstract

Introdução

Capítulo I $\quad 5$

1 Geografia e Relações Raciais 6

1.1 Estado-Nação e Raça: o tempo e o espaço na 10 modernidade

1.2 Nação e Raça no pensamento social brasileiro 13

1.3 Espaço e Miscigenação 15

Capítulo II 17

2 Idéias fundadoras da civilidade brasileira: o 18 pensamento social

2.1 A tese do branqueamento 21

2.2 A democracia racial brasileira 24

Capítulo III 31

3 Idéias formadoras da civilidade brasileira 32

3.1 A formação sócio-espacial brasileira: raça e 35 racismo como rugosidade do espaço geográfico

3.2 Políticas estatais de dominação racial: sistema 40

3.3 O sistema educacional 44

$\begin{array}{lll}3.4 & \text { Emprego Informal } & 70\end{array}$

3.5 Renda do Trabalho 60

Capítulo IV $\quad 76$

4 Movimento Social Negro: idéias reivindicadoras de 75

civilidade

4.1 Movimento Social Negro e Estado 76

4.2 Organizações Negras: Imprensa Negra - Frente 76

4.3 Ações e discursos 81

4.4 Histórico governamental 82

Considerações Conclusivas 108 
Resumo

\title{
Resumo
}

A presente pesquisa tenta analisar as idéias e ideologias raciais em perspectiva geográfica. Busca demonstrar que estas idéias são parte de um sistema de ações indissociáveis dos arranjos espaciais. Estes arranjos espaciais são desigualmente usaos e acessados por negros e brancos. O uso diferenciado e desigual do espaço geográfico gera por parte do grupo negro a formulação de outras idéias (ações) em reação ao primeiro.

\begin{abstract}
This research tries to analysis how racial ideas and ideologies are geographically produced. The study is also a tentative to demonstrate that ideas are part of a system formed by actions not-dissociated of space.

The way in which the geographical space have been used and arranged by black and white people are convincing evidence of historical inequalities among both population.
\end{abstract}

Key words: racial ideologies, system of actions, geographical space. 


\section{1 - Geografia e Relações Raciais: pressupostos teóricos}

O estudo de relações étnico-raciais em sociedades multirraciais, de passado escravista e colonial, como a sociedade brasileira, por si só em nosso entendimento, já é de relevância justificável. Seja pelas diversas contribuições técnicas e culturais, propriedade intelectual dos diferentes grupos étnico-raciais formadores do que hoje é a nação brasileira. Seja pela desigual relação desses grupos com a estrutura do Estado brasileiro, o que em outras palavras implica pensá-las em termos socioespaciais.

Para (SANTOS, 1996/1997, p.79-80) a compreensão da questão étnicoracial no Brasil, passa pela compreensão do modelo cívico, modelo cultural e do modelo político brasileiro, portanto pela compreensão dos sistemas de idéias interpretativas, fundadoras e formadoras da "civilidade" brasileira. A essas idéias acrescentaremos idéias constestadoras e reivindicadoras de civilidade, sobretudo expressas nesta pesquisa pelo movimento social negro.

Para realizar o estudo das relações raciais em perspectiva geográfica, partiremos inicialmente da assertiva marxista de que a desigualdade no modo de produção capitalista é transmitida de uma geração a outra, porém buscando demonstrar que a persistência da desigualdade no Brasil é agravada pela existência de uma linha de cor, demarcatória da mobilidade socioeconômica e espacial dos grupos étnicos e raciais existentes.

O processo geo-histórico do escravismo promoveu a partir do século $\mathrm{XVI}$, a imigração compulsória de milhões de africanos para o Brasil, desde então este evento vem demarcando a dimensão racial ${ }^{1}$ como elemento de estruturação da vida sócio-espacial desse grupo e dos seus descendentes no país. E trezentos anos mais tarde a imigração subvencionada de diversos grupos de europeus para

\footnotetext{
${ }^{1}$ Cabe esclarecer que o termo racial esta sendo utilizado em seu sentido político, re-significação dos Movimentos Negros, que ao fazê-la mantém estrategicamente na pauta das políticas atuais, a natureza discriminatória, excludente e metamórfica, que caracterizaram as relações raciais brasileiras, que fizeram da origem racial, da cor da pele, do cabelo e de outras determinações fisionômicas de diferenciação discriminatória, fator de destino do lugar social dos sujeitos no interior da sociedade brasileira.
} 
o país demarcará a dimensão étnica ${ }^{2}$, também como elemento dessa mesma estruturação.

Etnia e raça para a geografia podem ser operacionalizadas analiticamente como fronteiras e limites de ação dos europeus e seus descendentes e de africanos e seus descendentes no Brasil. Enquanto no século XIX a introdução do imigrante europeu projetava a expansão e a colonização do território, uma nítida estratégia de fronteira (Osório, 2003). A presença africana e de seus descendentes representava para a elite nacional da mesma época, atraso e primitivismo, limites internos ao progresso almejado.

A valorização histórico-cultural de europeus, em relação aos povos de outros continentes, africano e americano, decorre etnocentrismo promovido pela universalização do capitalismo como processo econômico impulsor de formas políticas como o Estado-nação. Ao fim do século XIX, a industrialização e o Estado-nação, simbolizavam para o mundo, progresso econômico, cultural e político, divisor de águas entre povos "civilizados" e povos "primitivos".

Para boa compreensão da diferença valorativa entre etnia e raça, valeria destacar duas escalas de análise possíveis, uma continental, de caráter civilizatório, onde a Europa é homogeneizada como grupo racial superior. Outra local, de caráter essencialista, que pluraliza etnicamente as nacionalidades políticas ${ }^{3}$, em função da história, cultura, tradições, feitos e símbolos "comuns" ao país ou coletividade em questão.

Os europeus dessa forma foram classificados do ponto de vista racial, como brancos, racialmente superiores. E do ponto de vista étnico, pela nacionalidade política. São assim: italianos, espanhóis, alemães, ingleses, franceses etc. No Brasil cada nação européia representa em si parte cultural de um todo civilizado.

\footnotetext{
${ }^{2} \mathrm{O}$ termo étnico é empregado, antropologicamente, como fenômeno cultural que enfatiza as características de vidas passadas e coletivamente compartilhadas por um grupo.

${ }^{3}$ Aqui empregado com o sentido de pertencimento a uma comunidade política, Estado-nação
} 
Já, povos ameríndios e africanos, pertencentes a contextos sociopolítico e econômico diferentes da lógica de produzir do modo capitalista e que portando não "inventaram" ou que por opção "desprezaram" o Estado-nação, como forma de organização política regida por um contrato social, só racialmente foram considerados. As diferentes etnias africanas foram agrupadas racialmente como negras, essencialistamente homogeneizadas e emparedadas pela cor da pele, ainda hoje, os imigrantes de países africanos, são comumente denominados africanos e não por suas nacionalidades políticas ou étnicas. Este fato também se dá com as etnias indígenas nativas do Brasil que são comumente tratadas como grupo de origem racial homogêneo e não como grupo etnicamente diverso.

Para lanni, (2004, p. 17) a transformação de uma etnia em raça se dá como uma técnica de dominação. Isto porque as relações sociais entre os grupos são hierarquizadas e desiguais. Essa transformação, objetiva a redução de participação na economia, na política e na cultura, propiciando também a alienação. É a fabricação contínua do outro e momento de emergência do preconceito racial.

De acordo com Michel Banton (apud CASHMORE, 2000, p. 198) a diferença entre grupo étnico e grupo racial é que enquanto o primeiro reflete tendências positivas de identificação e inclusão, o segundo reflete as tendências negativas de não-associação e exclusão.

Um bom exemplo dessa diferenciação valorativa é o brilhante artigo de Seabra, (2001, p.78) sobre a importância do estudo de bairro e memória urbana nos processos de metropolização da cidade de São Paulo. O tema das relações étnicas e raciais, ainda que não explicitamente, aparece abordado.

Seabra reconhece o caráter segregador de natureza racial, presente na relação entre brancos e negros, apontando que os negros convertidos à religião cristã foram levados a construírem suas próprias igrejas e ordens religiosas separadas dos brancos. 
O intrigante da análise, isto do ponto de vista das relações étnico-raciais é o fato de que embora o conflito tenha sido observado sua importância é minimizada. Não aparece como conflito inter-classe, ou como uma das características que dão conformação a cidade; a de abrigar relações étnicas e raciais conflituosas e em função dessa característica, produzir espaços de segregação social de natureza racial, como as ordens religiosas separadas, ou alguns bairros no passado.

Sua conclusão sobre a participação dos negros na cidade é ainda mais emblemática, senão, vejamos: "Não obstante, os negros não tivessem tido, em São Paulo, a importância que tiveram nas lavouras do nordeste e mesmo na capital federal." Para um pouco mais a frente destacar que a base cultural e social da cidade foi formada do perfil étnico caboclo e do modo de ser caipira, além da modernização decorrente da entrada imigrante.

Santos (1998, p.62-5) ao contrário de Seabra, reconhece a importância histórica da presença imigrante, porém tece críticas tanto a literatura de viajantes, cronistas, homens de governo da passagem do XIX, para o XX, como a Historiografia Social do Trabalho que construiu a imagem da classe operária paulistana, como sendo uma classe operária européia. E com isso, minimizou a importância de outros sujeitos históricos e suas realidades, social, política, econômica e cultural.

Caberia então perguntar à Seabra, se no período em questão, final do XIX e início do $\mathrm{XX}$, em que boa parte da população negra da cidade era oriunda das fazendas do interior do estado, ou das cidades vizinhas de Minas Gerais, se os negros a quem se refere não são também caipiras. Ou se são "apenas" negros, ou ainda, se caipiras negros, o que de qualquer modo seria paradoxal, já que para este autor a importância dos negros em São Paulo foi pequena.

Obviamente que não estamos atribuindo à Seabra qualquer juízo valorativo de ordem racial. Apenas demonstrando por meio de suas próprias observações, que há na sociedade brasileira de um modo geral e entre os geógrafos de maneira mais específica uma insensibilidade ao tema. Talvez herança de uma orientação marxista ortodoxa que a partir dos anos 70 se instala na geografia impedindo-a de 
enxergar conflitos interclassistas fora da esfera produtiva. Muito embora saibamos dos inúmeros estudos sobre imigração, colônias de imigrantes, caiçaras, caipiras e mais recentemente mulheres, produzidos nos últimos trinta anos.

Esta distinção valorativa entre étnico e racial, constitui-se em traço fundante da nacionalidade brasileira. Que política e ideologicamente foi concebida, em torno de um projeto de nação assentado no branqueamento da população.

Elaborada com propósitos eugenistas de povoamento e civilização a ideologia do branqueamento, naturalizou-se em nossa sociedade como mentalidade, incorporada tanto pelo senso comum como pelo saber culto.

Para Lukács, (1970, p.260) as ideologias, - sistemas de idéias, evidenciam as formas de agir, pensar e analisar sobre as coisas - relações entre homens. E sobre os fatos - momentos desse processo.

As relações étnicas e raciais para Miles, (2000, p. 485-8) se constituem em subcategorias das relações sociais e expressam para a sociologia das relações raciais, relações entre grupos sociais que empregam a idéia de "raça" na estruturação de ações e reações entre si.

Em outra perspectiva, ainda no campo da sociologia, Banton (apud CASHMORE e TROYNA, 2000, p.489) caracteriza as relações raciais como uma forma específica de relacionamento social que ocorre em três níveis: o da descoberta de razões que levam a crença da diferença cultural e biológica; o da descoberta de como essa crença afeta as suas ações em relação aos outros assumindo a forma de manutenção social e geográfica de distância; e por último, no nível analítico de como as crenças e terminologia perpetuam um contexto no qual o conceito de "raça" continua a ter importância.

Também para a compreensão de contextos sociais de formulação de idéias, interesses, conflitos e concepções vigentes na sociedade, porém em perspectiva geográfica, Moraes, (2002, p.14) propõe três níveis de abordagem: o do horizonte geográfico, caracterizado pelas relações cotidianas; o do pensamento geográfico, representação e consciência literária, filosófica e científica coberta pelo saber acadêmico; e o das ideologias geográficas, representação com direcionamento 
político explícito, orientado para a produção do espaço material e para a construção de juízos e valores que moldam as próprias formas de consciência.

\section{1 - Estado-nação e raça: ou tempo e espaço na modernidade}

Muito embora o conceito "científico" de raça e as teorias raciais sejam formulações do século XIX é no século XIV, segundo Banton, (2000, p.447) que os primeiros registros do uso do termo, surgem na maioria das línguas européias significando grupo ou categoria de pessoas conectadas por uma origem comum.

Ainda segundo Banton é no século XIX, que a palavra raça ganha novo significado passando a ser usada de forma tipológica, com o sentido poligenista de distinção entre grupos de indivíduos da espécie humana, expressando tanto distinção física como também mental.

A re-significação conceitual de raça, realizada pelas ciências no século XIX, com a alteração do sentido lingüístico de conexão, para o sentido "científico" de distinção, serviu aos interesses dos grupos dominantes europeus e às necessidades internas e externas de expansão, dominação e unificação política, econômica e territorial dos Estados-nação.

Para Silva, (2002, p.43) "o conceito de raça era necessário para definir o espaço da modernidade (...) o racial foi elaborado como um conceito que se refere ao espaço, ao corpo e ao continente." Em outras palavras ao território da nação, ao homem branco e ao continente europeu, todos compartilhando o tempo da modernidade que pode ser entendido também, como o tempo da civilização, da nação moderna.

O contexto histórico-social da re-significação de raça é o da emergência do Estado-nação, que em sua base constitutiva é formado pelo tripé população, recurso e território, como apontou Ratzel nos primórdios da geografia moderna.

Bem, desdobrando cada elemento desse tripé e avançando a partir da visão ratzeliana, o território é a condição de existência material do Estado, os recursos 
são as potencialidades para produção material da sociedade e a população enraizada nesse espaço, a responsável pelo uso, ocupação, exploração e defesa do território.

Para Ratzel o grau de desenvolvimento de qualquer Estado estaria diretamente ligado ao equilíbrio entre estes três elementos. Dessa forma, o Estado-nação e seus desdobramentos surgem como produção histórica da relação sociedade-espaço. $E$, somente em condições históricas específicas e particulares pôde ser "inventado". E a partir de sua "invenção" produzir novos espaços e territórios. Meio geográfico das diversas sociedades, utilizados, para fins de reprodução das relações sociais de produção, universalizadas pela unicidade das técnicas imposta pelo modo de produção capitalista.

Erick Hobsbawm (1990) periodiza a invenção do Estado-nação em três, etapas, de 1830 a 1880 , de 1880 a 1918 e de 1918 a 1950-60, afirmando que em países como a Alemanha, os Estados Unidos o Estado-nação teve por função principal o protecionismo da economia nacional frente ao interesses externos.

Essa função protecionista gera contradição no Estado-nação em sua fase liberal burguesa. Ao mesmo tempo em que se constitui em uma entidade de proteção do nacional frente ao avanço comercial e territorial do externo sobre este interno, fundamenta-se em princípios de expansão comercial e territorial do interno nacional sobre o internacional.

O período entre 1830 a 1880 é para Hobsbawm a fase do "princípio de nacionalidade", caracterizado pela delimitação e expansão do espaço territorial nacional.

O segundo período vai de 1880 a 1918, é o da "idéia nacional", que busca articular o valor material do território, ao valor cultural das tradições, da língua, religião e raça, com o propósito de unificação. Se no primeiro período a formulação teórica vem da economia, carente de proteção e regulação, neste segundo período, origina-se da intelectualidade pequeno-burguesa. 
No início de sua delimitação territorial, o Estado-nação na Europa se deparou com conflitos internos, promovidos por grupos étnicos diversos, reivindicadores de independência para constituição de nacionalidades próprias, o que por vezes, significou a fragmentação da unidade territorial antiga ou pretendida, em novas unidades territoriais autônomas e distintas.

Além dos conflitos étnicos, ameaçadores da unidade territorial e social da Nação moderna, intensificam-se os antagonismos de classe decorrentes do processo latente de industrialização e urbanização européia e da contradição capital-trabalho. É neste quadro, de tensões econômica, social e política, em que a modernidade capitalista encontra-se ameaçada pela emergência das lutas socialistas e pelas tradições ancestrais de origem étnicas, que a "idéia nacional" é formulada.

A nacionalidade - "espírito do povo" surge como a "alma" da nação, a essência da "idéia nacional", que encontrou na língua, na religião e na raça, atributos de delimitação, posse e critérios definidores do território-nacional.

Além de princípio vivificante da nação emanado pelo povo, a nacionalidade se definirá como norma jurídico-política do Estado-nação, garantia e direito constitucional concedido pelo Estado-nação e adquirido pelo filho da pátria, em sociedades modernas pelo jus sanguini ou jus soli ${ }^{4}$.

\footnotetext{
4 Nas nações européias há um predomínio do jus sanguini, direito a nacionalidade concedida pelo sangue, portanto um direito hereditário que durante o século XIX reforçava a concepção de raça. Neste caso a nacionalidade é herdada através do sangue e perpetuada mesmo distante da pátria, pela língua, costumes e espírito próprio da nação, "espírito do povo". No Brasil prevalece o jus soli, como a nação estava em formação, recém liberta da sujeição colonial e a raça, "degenerada" pelo "viciado" sangue africano e indígena, por isso não podendo ser evocada como atributo valorativo, identitário e de unidade da nação, valoriza-se o direito ao solo como condição de pertencimento a nação.

$\mathrm{O}$ jus soli permiti perceber a influência que as idéias introduzidas pelo racismo científico e determinismo geográfico exerceram sobre a elite brasileira no século XIX. Thomas Buckle, historiador inglês, assim descreveu o Brasil "[...] em meio a essa pompa e fulgor da natureza, nenhum lugar é deixado ao homem. Ele fica reduzido à insignificância pela majestade que o circunda [...] Em nenhum outro lugar há tão penoso contraste entre a grandiosidade do mundo exterior e a pequenez do interno.” (apud SKIDMORE 1976, p.44-5) A influência que racismo científico e que determinismo geográfico exerceram sobre o pensamento nacional, se expressa pela troca proposta pela elite brasileira. O imigrante europeu entraria com o sangue "branco" regenerador da "raça brasileira" e o Brasil, com o solo, (natureza) pomposo, majestoso, rico, extenso, pronto para ser colonizado pelo sangue civilizador.
} 


\section{2 - Nação e raça no pensamento social brasileiro}

A grande mobilização da elite e intelectualidade brasileira na passagem do século XIX para o XX era o de fundamentação teórico-científica da nação brasileira. Essa mobilização era impulsionado pelos processos de construção do Estado-nação e o de adequação do território, a modernização capitalista, promovida pela primeira revolução industrial.

Anderson (2005) chama a atenção para o fato de Estado-nação aglutinar conceitos diferentes que podem ou não casarem adequadamente. Em linhas gerais, para Ratzel o Estado é a sociedade organizada em defesa de um território. E para Leite (1983) a nação para Leite se define em termos de caráter e identidade nacional.

De acordo com Odalia (1997) o projeto de nação do Brasil foi tanto uma idealização como construção, pois, consubstanciou ideais e anseios de grupos sociais capazes de compreender para seus próprios fins o sentimento nacional e a nacionalidade. E construiu instrumentos políticos e persuasórios de transformação da massa heterogênea em povo.

Um projeto, nunca é demais insistir-se nesta sua faceta é fruto tanto em sua elaboração quanto em sua execução - de uma vontade e de uma consciência. (...) Sua verdadeira face se revela quando o percebemos como a expressão de uma concepção do mundo em que o fator político ganha relevo. O político aqui deve ser compreendido tanto como preocupação de elaborar uma ideologia quanto como o desenvolvimento de uma prática política que nela alcance seu modo de ser.

A prática política, de construção da nação, se efetivou através de formas estatais discriminatórias de dominação racial, não-legais do ponto de vista jurídico, já que não foram escritas em nenhum documento, mas informalmente institucionalizadas como discriminatórias. $O$ fato de não se encontrarem escritas 
não impediu que fossem praticadas com muita eficiência em seus propósitos de apartamento sócio e espacial de negros e indígenas.

Coube aos intelectuais a função de fundamentação teórica da prática política. A estrutura oligárquica da sociedade brasileira unificou a elite, fundindo políticos e intelectuais em um só grupo de interesse que teve a questão racial, como tema central da questão nacional.

O advento do racismo científico no século XIX, idéia desdobrada da teoria revolucionária de Darwin exerceu forte influência sobre o pensamento nacional. Enquanto idéia hegemônica de um período, o racismo científico transformou a miscigenação, principal característica demográfica da população brasileira, em problema central, impeditivo do progresso do país. E sobre este problema por cerca de um século se debruçaram políticos e intelectuais representantes da elite nacional.

Os conceitos de hereditariedade, pureza racial, clima e meio físico natural são as determinações explicativas do progresso das nações. Dessa forma aquilo que racialmente e climaticamente fosse diferente das características humanas e físicas naturais da Europa era pelo racismo científico condenado ao insucesso civilizatório. É com base nesse argumento que o racismo científico, lança dúvidas sobre as reais possibilidades de progresso das nações racialmente impuras, ainda mais localizadas em áreas tropicais.

\section{3 - Espaço e Miscigenação}

Muitas são as explicações sobre a miscigenação no Brasil, atribuindo-lhe aspectos de natureza biológica, religiosa, além da propalada "afetuosidade" das relações entre senhores e escravos e da "singular predisposição portuguesa", principais fundamentos antropológicos da obra de Freyre. 
Muitas também são as críticas, dirigidas a explicação de Freyre, fugiremos da polêmica, talvez criando outra de natureza geográfica, talvez melhor dizer de dinâmica espacial, pois buscamos entendê-la e explicá-la em sua origem, como fenômeno espacial, já que está ligada ao uso e função dada as terras brasileiras pela coroa portuguesa.

Enquanto as colônias de povoamento, anglo-saxãs, na América do norte, se caracterizaram pela organização espacial na forma da pequena propriedade produtiva, mais adequada a projetos de povoamento. A colonização lusa em terras brasileiras se caracterizou pela exploração e pela organização espacial em grandes latifúndios, destinados a exploração de riquezas e a monocultura da cana.

A colonização do Brasil partiu de um alto investimento do Estado português que por essa razão intervém de maneira centralizadora, fragmentando o solo das vastas terras coloniais em poucas, porém extensas áreas territoriais (capitânias hereditárias) com o firme propósito de assegurar o controle.

Ao contrário, na colonização norte-americana onde o investimento foi privado, a fragmentação do solo ocorre em unidades territoriais menores, (pequena propriedade produtiva) de interesses mercantis mais difusos.

A diferença entre o investimento centralizado do Estado e o investimento mais difuso do capital privado se manifestou nas terras coloniais na forma espacial do grande latifúndio e da pequena propriedade produtiva. Tanto que para Caio Prado Jr o grande latifúndio é um dos tripés explicativos da formação do Brasil contemporâneo, sendo que os outros dois são a monocultura e o trabalho escravo.

A origem dos investimentos definiu a função econômico-espacial da colônia e conseqüentemente sua organização do espaço para o atendimento dessa 
função. A quantidade de mulheres ${ }^{5}$ na composição demográfica das duas colônias é outra diferença decorrente da função espacial atribuída a cada uma delas.

$\mathrm{Na}$ colônia de povoamento norte-americana a presença da mulher foi central, para assegurar o povoamento e relações raciais mais endogâmicas, ainda que não fosse este último seu principal propósito. Mas é fato que esta condição contribuiu preponderantemente na formação de grupos raciais mais homogêneos. Já na colonização do Brasil, o modelo de exploração das riquezas, com a quase ausência de mulheres brancas, propiciou inversamente, grupos raciais mais heterogêneos, produto de relações sexuais exogâmicas.

Vale a pena reforçar que a miscigenação brasileira sem o advento do racismo científico seria meramente o resultado do cruzamento de indivíduos, um fenômeno biológico.

Porém, sob os efeitos negativos impostos pelo racismo científico, se constituiu em fenômeno social, detentor de ordem hierárquica estruturante da sociedade brasileira. Pode-se dizer que como estrutura é também processo social fundador da nação.

\footnotetext{
${ }^{5}$ Ver página 69 do meira mattos citar os números de mulheres no Piauí em 1697
} 


\section{SEGUNDO CAPÍTULO}

Idéias fundadoras da civilidade brasileira: o pensamento social

2 - idéias fundadoras da civilidade brasileira: o pensamento social 
Duas são as idéias que trataremos como fundadoras da civilidade brasileira, isto porque ocupavam ao seu tempo e ainda hoje ocupam o centro do pensamento social brasileiro: a tese do branqueamento e a louvação a mestiçagem, posteriormente traduzida como democracia racial brasileira.

Para desenvolver esse par de idéias, emprestaremos de Chauí, (2000, p. 9) a definição de fundação, como sendo toda ação que "impõe um vínculo interno com o passado como origem, isto é, com um passado que não cessa nunca". Para este autor a peculiaridade da fundação é a transcendência e a imanência do momento fundador, " a fundação aparece como emanando da sociedade (em nosso caso nação) e, simultaneamente, engendrando essa própria sociedade (ou nação) da qual ela emana." É dessa mesma forma que concebemos a tese do branqueamento e a democracia racial brasileira, esta última embasada na tese da existência de relações raciais "tolerantes" e "afetuosas"

Em nossa visão a formulação de idéias está diretamente ligada a condições geográficas (portanto técnicas) específicas que variam em intensidade e duração em função da escala, se mundial, nacional, regional, ou local. Mas invariavelmente estão associadas a três fatores: ao momento sociopolítico do seu lugar de formulação; aos interesses da classe ou formuladores das idéias; e as idéias mais em voga na ocasião de sua formulação, como sugeriu Leite, (1983) ao estudar o pensamento social brasileiro.

Já indicamos que uma premissa desta pesquisa é a da indissociabilidade do espaço geográfico enquanto sistema de ações e sistema de objetos e que as ações são tomadas como idéias que se materializam geograficamente. A partir dessa premissa concebemos a relação étnico-racial brasileira em dimensão geográfica, como espacialidade da vida social, pois se manifesta através das instâncias, econômica, política e cultural.

O racismo científico, teoria que influenciou a natureza das relações étnicoraciais brasileiras ao seu tempo se constituiu em idéia hegemônica, 
universalmente difundida como verdade absoluta, científica, e, por isso irrefutável. Já vimos como sua difusão influenciou o pensamento nacional.

Para Raffestin (1993, p. 132) a discriminação racial resultante do racismo, envolve todo um conjunto de dispositivos possíveis que tomam formas diversas para que um grupo aumente seus trunfos em detrimento de outros grupos. "É a introdução do conceito de discriminação que permite reduzir a competição do grupo ou dos grupos concorrentes em relação aos trunfos."

A tese do branqueamento e a ideologia de louvação a mestiçagem foram idéias nativas derivadas do racismo científico que internamente, na escala do país, produziram e ainda produzem espacialidades ${ }^{6}$ distintas entre negros e brancos, produto das discriminações que acompanham essas duas ideologias.

Embora Raffestin, ao contrário do que estamos propondo fale de discriminação espacial apenas como localização, sua reflexão serve ao nosso propósito porque reconhece a discriminação como uma interjeição que varia do individual ao coletivo em termos de acesso ao território, destacando que se caracterizam pela edificação de "fronteiras invisíveis" que se instalam estabelecendo relações dissimétricas no uso do espaço pelos grupos concorrentes. Como exemplo, vale a pena comparar a desigualdade de prestígio e salário entre negros e brancos no exercício da mesma função.

Para além de tese, o branqueamento do país se materializou no espaço geográfico em diferentes formatos da qual a imigração européia, talvez seja o de maior amplitude e desdobramento, pois exigiu organização normativa e técnica do território, intercambiada por firmas e instituições ${ }^{7}$. Debate político sobre o tipo ideal

\footnotetext{
${ }^{6}$ Dimensão geográfica de fenômenos sociais que muito mais que a simples localização expressa uma situação, ou estado: de ocupação, renda, saúde, escolaridade, do país, das regiões e dos grupos sociais de um dado lugar ou território. Dessa forma tanto faz parte como designa a formação econômica, social e espacial, evidenciando a diferenciação entre pessoas, lugares, entre o ser o estar e o fazer.

${ }^{7}$ Em Espaço e Método, Milton Santos (1985) aponta cinco elementos formadores e constituintes do espaço geográfico: a saber: homens, firmas, instituições meio ecológico e infra-estrutura. Define-os como elementos
} 
de imigrante, - se germânico, latino ou de outra origem, - havendo apenas consenso de que seria homem branco ${ }^{8}$, naquele momento, idealizado como principal elemento de transformação civilizatória da nação. O impacto da numerosa presença imigrante exigiu ainda políticas específicas de subvenção, transporte, acomodação, incorporação como mão-de-obra e de assimilação biológica e cultural.

Em perspectiva mais comparativa o sucesso socioeconômico de imigrantes e seus descendentes em relação a africanos e seus descendentes, mais do que destacar "mérito" dos primeiros e incompetência dos últimos, revela a eficiência da ideologia racial, Já que boa parte dos imigrantes, contrariando a própria representação que deles se fazia chegou aqui analfabeto e com precária qualificação profissional, (Farias, 2005, p. 23) portanto, muito parecidos com os trabalhadores negros, preteridos para o trabalho assalariado.

Martins (1981) refletindo sobre a produção ideológica do trabalho, chama a atenção para a eficácia dessa ideologia que foi elaborada pela classe dominante em torno da imigração italiana. Martins destaca a combinação contraditória entre a produção direta dos meios de vida e a produção de mercadorias, destacando que existe por parte de alguns autores um exagerado culturalismo em torno do trabalho imigrante e do próprio imigrante, idealizado pela burguesia agrária, como trabalhador árduo, resignado, ciente de que a compensação que só viria através de muito trabalho.

Do mesmo modo, as origens da ideologia da mobilidade pelo trabalho não correspondem a idéias comuns a vários cientistas sociais. Algumas pessoas crêem que ela é essencialmente produzida pelo próprio imigrante. As minhas pesquisas, no entanto, mostram que ela foi produzida pela burguesia para o trabalhador imigrante. A burguesia

porque em conjunto ou isoladamente em momentos distintos fizeram parte da história. São variáveis que podem ser intercambiadas, estudadas em conjunto e isoladamene. 
agrária estabeleceu as condições e vias para receber e assimilar o imigrante. Este não teve, em princípio, outro caminho senão se conformar a essas condições. Em outras palavras, sua assimilação consistiu em orientar suas aspirações para os canais institucionais definidos pela classe dominante de modo que, ainda que com alguma tensão e descaracterização, ele acabasse se concebendo de acordo com as necessidades históricas daquela classe. (MARTINS, 1981, p. 129)

As considerações de Martins permitem identificar a institucionalização da assimilação imigrante promovida tanto pelo Estado como pelo capital privado. Independente das dificuldades encontradas para sua fixação no Brasil, em comparação aos negros, os imigrantes sempre possuíram maiores oportunidades de mobilidade social através do trabalho, primeiro pela preferência, em outras palavras, pela discriminação de negros e depois, ainda dentro dessa mesma lógica, não trabalhavam só para os patrões, ainda que explorados, também trabalhavam para si mesmos, isso não ocorrendo em grande escala com os negros.

\section{1 - A tese do branqueamento}

O ápice da tese do branqueamento ocorreu entre 1870 a 1930, período marcado pelo fim do Segundo Reinado e início da Primeira República. Caracterizou-se sociopoliticamente por duas fases, até 1889, marcada pelo debate abolicionista e a despeito de negros, indígenas e mestiços por criar uma nação a imagem e semelhança da Europa. E a segunda fase, já na Primeira República, caracterizada pelo descentralismo político das oligarquias e coronelismo, camada social de base rural, detentora da terra e do poder político local.

\footnotetext{
${ }^{8}$ Conceber o espaço geográfico através dos seus elementos como um sistema indissociável, permiti adjetivar cada um dos elementos em função do contexto sociopolítico que ele se encontra, assim os homens podem ser firmas, instituições ou qualificados por algum adjetivo que os defina em função do tempo e do espaço.
} 
O coronelismo funcionava por leis próprias, exercidas a base da coerção, força e pelo clientelismo. As oligarquias, com o advento do federalismo republicano atingem na Primeira República seu momento mais auspicioso em termos de poder político (tenho que detalhar melhor talvez dizendo que o poder ficou nacional).

Do ponto de vista da elaboração teórica da nação, o período entre 1870 e 1930 é o de formulação do caráter nacional, em outras palavras uma busca interpretativa da sociedade brasileira, a partir das suas três raças formadoras, empreendida pela elite política e intelectual do país.

Para Dante Moreira Leite, (1983) o pensamento social brasileiro concluiu uma interpretação pessimista do Brasil, obtida de maneira fragmentada e parcial sobre a natureza humana, mais precisamente sobre o caráter nacional, dos grupos raciais formadores da sociedade brasileira. O pessimismo é fruto da forte influência que o racismo científico e o determinismo geográfico exerceram sobre o pensamento social brasileiro, levando-o a produzir uma elaboração teórica pessimista sobre a nação.

Em linhas gerais a tese do branqueamento consistia na introdução de população branca imigrada da Europa e na assimilação simbiótica do imigrante europeu, biológica e culturalmente. A idéia principal embutida na tese era de que o cruzamento do branco com europeu com o nativo produziria um indivíduo melhorado e a repetição continua dessa mistura ${ }^{9}$ produziria em alguns anos o branqueamento total da nação. Vejamos Sílvio Romero:

"A minha tese, pois, é que a vitória na luta pela vida, entre nós, pertencerá, no porvir, ao branco; mas que esse, para essa mesma vitória atentas as agruras do clima, tem necessidade de aproveitar-se do que de útil as outras duas raças Ihe podem fornecer, maximé a preta,

\footnotetext{
${ }^{9}$ Para Seyferth, (1991) um dos paradoxos da miscigenação brasileira é combater a mistura racial com mais mistura racial.
} 
com que tem cruzado. Pela seleção natural, todavia, depois de prestado o auxílio de que necessita, o tipo branco irá tomando preponderância até mostrar-se puro e belo como no velho mundo. Será quando já estiver de todo aclimatado no continente. Dois fatos contribuirão largamente para esse resultado: de um lado, a extinção do tráfico africano e o desaparecimento constante dos índios, e de outro a emigração européia". (apud. SKIDMORE, 1976, p. 53)

Pela exposição de Romero, fica evidente a influência exercida pela teoria de superioridade racial branca; e a disposição ao isolamento e ao desaparecimento de negros e índios, vistos como obstáculos ao projeto de nação. Os alvos do branqueamento são os mestiços e brancos nativos.

Talvez o grande paradoxo da tese de branqueamento foi combater a mistura racial com mais mistura racial e fazer da imigração européia uma ação recolonizadora e principalmente "civilizadora" do país. O branqueamento seria a solução simbiótica de transformação do imigrante e seus descendentes em brasileiros e o Brasil em Europa.

Seyferth,(1999, p. 274) aponta que no sul do país, desde 1824, a imigração promoveu um aumento de população branca, porém com a ressalva de que em termos de assimilação biológica e cultural os resultados foram quase infrutíferos, pois os imigrantes europeus, principalmente os de origem germânica, se mostraram resistentes a assimilação cultural e biológica. Vivendo em pequenas propriedades produtivas se constituíram em verdadeiro grupo fechado.

Entre as medidas tomadas para obtenção de sucesso nessa política de branqueamento da nação pode-se destacar a restrição à imigração de africanos e asiáticos para o país expressa na Constituição de 1891, em oposição aos incentivos, promessas e subvenções federais e dos estados destinadas a imigração européia. 
A efetivação da tese branqueamento demandou ações normativas de natureza política, bem como técnicas de organização do espaço geográfico, como a construção de estradas de ferro, rotas, portos, estalagens etc.

Entre 1890 e 1944, cerca de 2,5 milhões de europeus foram introduzidos no país, elevando a taxa de brancos no total da população. Esse aumento se deu mais pelo forte incremento promovido pela imigração do que pela sonhada assimilação biológica. Em pouco mais de cinqüenta anos, o resultado da política de branqueamento, obteve certo sucesso, porém não sem tensões e conflitos.

O acelerado crescimento populacional, opôs trabalhadores nativos a trabalhadores imigrantes, os nacionais passaram a hostilizar os trabalhadores imigrantes, concorrentes a oferta de trabalho. Essa insatisfação por razões diferentes atingiu também os empregadores que se irritavam com as organizações anarquistas e socialistas e com as reivindicações trabalhistas trazidas da Europa.

Em termos políticos essa insatisfação gerou um sentimento xenófobo de direita travestido de ultranacionalismo, nazi-facista, que teve a classe média paulista como principal protagonista que acabou por culminar no movimento Integralista de 1932.

Já vimos que a organização do espaço geográfico em pequenas propriedades privadas, favorece relações endogâmicas, que por sua vez tendem a preservar a homogeneidade biológica e cultural do grupo étnico. E como mais um paradoxo da ordem racial brasileira, a resistência do grupo germânico, se baseava na mesma crença racista de superioridade branca que influenciara a elite nacional, pois também aos olhos do imigrante europeu, assim como para Buckle e Gabineau havia no Brasil degenerescência da raça.

Em nenhum lugar há tão penoso contraste entre a grandiosidade do mundo exterior e a pequenez do interno...E a mente, acovardada por essa luta desigual, não só foi incapaz de avançar, mas sem ajuda 
estrangeira teria, indubitavelmente, regredido. Porque mesmo no presente, com todos os aperfeiçoamentos originários da Europa, não há sinais de progresso. (apud SKIDMORE, idem, p. 45)

“...nem um só brasileiro tem sangue puro porque os exemplos de casamentos entre brancos, índios e negros são tão disseminados que as nuanças de cor são infinitas, causando uma degeneração do tipo mais deprimente tanto nas classes baixas como nas superiores". (apud SKIDMORE, idem)

\section{2 - A democracia racial brasileira}

A transição teórica e prática da tese de branqueamento para a de louvação a mestiçagem, da qual a noção de democracia racial é resultante a nosso ver é o momento fundante da civilidade brasileira. Essas idéias surgiram incialmente como interpretações da realidade brasileira e ao longo do processo social e histórico de nossa formação se constituíram em ideologias. De acordo com M. Selinger:

“...conjunto de idéias pelas quais os homens [sic] postulam, explicam e justificam os fins e os meios da ação social organizada, e especialmente da ação política, qualquer que seja o objetivo dessa ação, se preservar, corrigir, extirpar ou reconstruir uma certa ordem social”. (apud EGLEATON, 1997, p. 20)

A tese do branqueamento e a louvação a mestiçagem enquanto sistema de idéias passou de conjunto interpretativo, para conjunto representativo da sociedade brasileira, de ação da elite intelectual à ação da elite política, se perenizou enquanto mentalidade, renovando-se a cada período histórico. 
Nesta pesquisa as idéias portadoras de conteúdo étnico-raciais foram separadas em três grupos, as fundadoras, as formadoras e as contestadoras/reivindicadoras da civilidade brasileira, tendo como respectivos protagonistas, o pensamento social brasileiro; o Estado brasileiro; e o movimento social negro.

Entendemos que para a Geografia, os momentos de transição da ordem social, expressam as mudanças ou alterações nas divisões internacional e territorial do trabalho. Com a conseqüente organização e reorganização do espaço geográfico, como por exemplo, na passagem do capitalismo mercantil para o capitalismo industrial, ou mais recentemente do industrial para o financeiro, com todos os arranjos nos sistemas normativos, e nos de infra-estrurura, necessários à sua realização em escala mundial. Como também na transição e transformação do Brasil de sociedade rural-agrária, em sociedade urbano-industrial, outro momento de ajustes, implicações e alterações.

Para lanni, (2004) o preconceito racial anda de par com o preconceito de classe e é constitutivo da sociabilidade brasileira'. Afirma que durante a vigência da escravatura formou-se uma poderosa cultura racista e aponta a contradição e o paradoxo das relações raciais no Brasil, interrogando, se num país em que as experiências de democracia política são precárias e a democracia social incipiente, se ainda assim é possível afirmar e reafirmar a existência de democracia racial ${ }^{10}$. "Quando pensamos que as relações sociais estão impregnadas pela idéia de democracia racial, descobrimos, então, que se trata de um mito cruel porque neutraliza o outro" (IANNI, idem, p.14).

Para Ribeiro (1997) foi o nacionalismo evidente de Freyre que o levou ao aprimoramento da tese de branqueamento, revertendo a história da escravidão e miscigenação brasileira de acontecimentos a serem apagados, para saga singular de uma nação.

\footnotetext{
${ }^{10}$ A crença de que não existe nem nunca existiu preconceito racial no Brasil. E que as condições de oportunidades são iguais, apenas dependentes da vontade e do esforço de cada um.
} 
Ao contrário dos críticos da história da nação brasileira, Freyre apontou exatamente a escravidão e a mistura racial como características singularmente positivas do Brasil, alicerçando a construção de uma identidade nacional, livre das normas e modelos americano e europeu, refutados em sua estadia para estudos nos Estados Unidos, nos anos 10 e 20 do século passado e pelo trágico desdobramento do racismo europeu em curso nos anos 30 e 40 do mesmo século.

O brilhantismo de Freyre, como teórico foi transformar a mistura racial em processo histórico; e o mestiço produto acabado da mistura, prova e possibilidade de relações raciais, afetuosas, tolerantes e democráticas. Freyre tanto rompe com a tese de branqueamento, ao realizar uma interpretação valorativa da história do Brasil, como paradoxalmente a reforça, estimulando a mestiçagem, já que a crença científica é regenerativa pelo sangue branco.

A louvação a mestiçagem de certa forma se constitui na antítese do branqueamento e ao mesmo tempo sua afirmação, ao transformá-lo de medida quantitativa e biológica em processo histórico qualitativo e de cultura da nação. Essa transformação elevou a tese de branqueamento à condição de ideologia nacional, a medida que branquear, a partir de Freyre e, não exatamente para ele, deixa de ter dimensão biológica, para ter dimensão social, mais precisamente passa embutir valor social.

Se realizada repetida vezes, a mistura racial branqueia, porém o produto da mistura do ponto de vista biológico será sempre impuro, ou pé na cozinha ${ }^{11}$. Já do ponto de vista social, "o pé na cozinha" pode ser branqueado, por uma "boa educação" que tende a maquear a origem racial. Para isto, basta ver como a história, por muito tempo "branqueou" mestiços, ou mesmo os invisibilizou em livros.

\footnotetext{
${ }^{11}$ Como se auto-declarou o até então presidente, Fernando Henrique Cardoso, personalidade brasileira socialmente branca
} 
Por uma impossibilidade biológica a sociedade brasileira abandona o conceito de pureza, sem no entanto, abandonar a noção de superioridade racial. Ao contrário, a reafirma não mais definida pela pureza da raça, (origem) mas por um continum hierarquizado de cor da mais clara a mais escura, a cor não como atributo genético, mas, sobretudo, como status e valor social associativo.

Os estudos de Freyre, informalmente tornaram-se a base de uma ideologia semi-oficial propagada em declarações públicas, pela mídia nacional, escolas e universidades. Isto pelo fato de a louvação a mestiçagem representar a louvação de uma nacionalidade comum, homogênea, sem diferenciação, bem de encontro aos interesses de centralização do poder e de unidade nacional do governo Vargas.

'O axioma da superioridade da 'solução' brasileira - e, portanto, de nossa construção de nacionalidade, com relação a norte-americana está profundamente arraigado, a ponto de nunca ser posto seriamente em dúvida. Pelo contrário, o discurso da área de 'relações raciais' no Brasil é um edifício impressionante e muito poderoso construído para responder ao essencialismo norte-americano [...] e à crítica norte americana da sociedade (e nacionalidade) brasileira. Esse eficiente edifício reativo (re)constrói a nacionalidade brasileira em oposição à norte americana. Uma das conseqüências mais palpáveis dessa (re)construção é a necessidade de neutralizar o discurso do movimento negro que é visto como caudatário direto do discurso essencialista norteamericano. Essa neutralização - qual academia e sociedade estão, por assim dizer, de mãos dadas no Brasil - dá-se através da desconstrução do discurso norte-americano, por um lado, e a construção da especificidade e diferença do discurso brasileiro, por outro". (RIBEIRO, 1997, p. 84)

Para Ribeiro, (idem, p. 86) a celebração da mistura, do contato, dos cultos afro-brasileiros, da figura da mulata é a prova incontestável da incorporação pessimista do julgamento racista do século XIX, pelos intelectuais adpetos da 
mestiçagem, isto porque não haveria razão em celebrar o que é nosso, já que é nosso. A celebração evidencia a presença de o apesar de em oposição ao a despeito de, que caracterizaria com mais precisão uma sociedade tolerante e racialmente democrática.

Alguns membros da comunidade negros individualmente e a Imprensa Negra mais institucionalmente, embora àquela época, em termos comparativos, reconhecem a ordem racial americana, a quem a louvação a mestiçagem se dirigia mais violenta e conflituosa que a brasileira, ponderavam o fato disso não implicar em relações raciais igualitárias, ao ponto de se enaltecer a relação racial brasileira. Outra constatação era de que nesta ordem racial democrática havia nítida preferência aos racialmente misturados de pele mais clara, em detrimento dos indivíduos de pele mais escura.

A relação entre mestiço e mistura racial pode ser comparada para fins analíticos e geográficos a relação entre forma e processo social, sendo que mestiço (forma) é definido ou redefinido socialmente (conteúdo) em função do processo (estrutura social) que the confere valor.

"O valor de um dado elemento do espaço, seja ele o objeto mais concreto ou o mais perfomante, é dado pelo conjunto da sociedade, e se exprime através da realidade do espaço em que se encaixou" Santos (2002, p.43)

Nesta perspectiva o valor do mestiço, enquanto forma espacial não é valor em si, mas valor, em relação a estrutura social que o circunda, variando desse modo no conteúdo, em função do processo social. Assim do descobrimento do Brasil, até mais ou menos 1830, valeu para a sociedade da época como recurso para a auto-colonização e trabalho no território. De 1830 a 1930, como obstáculo a civilização. E a partir de 1930 até nossos dias, como zona de fronteira, ardilosamente encaixada, por onde transitam as argumentações críticas e defensoras da ordem racial brasileira. 
Esse antagonismo entre acadêmicos e políticos de um lado e negros e instituições negras de outro, advém do fato, de que para academia, não há espaço à diferença dentro de uma nacionalidade inclusiva. Enquanto para o movimento negro, a não aceitação da diferença e a negligência a especificidade, discursada pela classe dominante e dirigente da nação, (Ribeiro) faz da nacionalidade brasileira uma garantia incompleta e um direito mutilado para os negros.

Por cerca de 50 anos, entre 1930 e 1980, período marcado pela industrialização concentrada, urbanização acelerada, redemocratização e ditaduras, o modelo racial brasileiro, vigorou, embasado na falsa idéia de ordem racial democrática. A louvação a mestiçagem surge primeiro como elaboração teórica interpretativa do Brasil, depois como representação simbólica e por último como ideologia fundamentada na existência de relações raciais afetuosas e tolerantes, que deram origem a crença de uma nacionalidade brasileira de caráter ${ }^{12}$ singularmente democrático.

Essa representação positiva emitida externamente por um dos seus intelectuais mais iminente e respeitado que inclusive se constituiu em discurso semi-oficial de Estado, levou a ONU, nos anos 50 escolher o Brasil, mais precisamente as relações raciais brasileiras, como campo de estudos sobre 0 racismo.

Vários fatores contribuíram para que essa representação se consolidasse em crença, entre eles: a criação por Vargas de um mercado de trabalho reservado aos brasileiros, preterindo estrangeiros que resultou em maior integração dos negros e mestiços ao mundo do trabalho ${ }^{13}$. A fase de redemocratização entre

\footnotetext{
${ }^{12} \mathrm{O}$ conceito de caráter que empregamos deve ser entendido como disposição natural de um povo e sua expressão cultural. Daí iniciarmos o primeiro parágrafo deste tópico com os questionamentos de Otávio Ianni a respeito das possibilidades reais de existência de uma democracia racial brasileira, pois assim também questionamos essa disposição natural. Outra acepção de caráter nacional que nos parece interessante é considerá-lo como conjunto de traços particulares, modo de ser de um indivíduo ou grupo que não necessita de referência externa.

${ }^{13}$ Minha avó, Maria Aparecida Gomes do Espírito Santo, sempre manifestou sua profunda gratidão, por Vargas "permitir", segundo ela, que as repartições públicas e algumas firmas contratassem negros, antes
} 
1945 e 1964, período em que vigorou no país um pacto e compromisso social, em que o conceito de democracia em oposição a ditadura do Estado Novo fluía como fundamento para realização da modernização integradora da nação. E como fator externo, o fim da $2^{a}$ Grande Guerra Mundial e a revelação ao mundo das atrocidades do nazismo contra os judeus, reforçava a idéia do Brasil como nação singular em termos de ordem racial democrática.

apenas confinados aos serviços de rua e em casas. Ela mesma, ex-empregada doméstica, orgulhava-se, assim como eu me orgulho dela ter sido servente de escola e ter se aposentado como funcionária pública. 


\section{TERCEIRO CAPÍTULO}

Idéias Formadoras da Civilidade Brasileira 


\section{3 - Idéias formadoras da civilidade brasileira}

No capítulo anterior destacamos que toda fundação impõe um vínculo interno com sua origem ganhando a forma de um passado que não cessa nunca. Vimos que no momento da fundação a nação surgiu emanada da sociedade e ao mesmo tempo engendrando essa mesma sociedade.

Da onde concluímos que a tese do branqueamento e a louvação a mestiçagem, são partes distintas, porém complementares de um mesmo sistema de idéias, ideologia, sintetizada na crença mítica de uma democracia racial brasileira.

Embora o conceito de ideologia não seja consensual, estamos buscando evidenciá-lo como a intersecção entre um sistema de crenças (idéias) e poder político, tanto o poder político emanante do Estado e das suas instituições e classe dirigente, como o poder emanado dos movimentos sociais, contestadores e reivindicadores da ordem social em vigência. 
A transformação da crença em discurso político do Estado, instersecciona o processo de fundação da nação, ao processo de formação do Estado, fundindo tempo (nação) ao espaço (Estado). Para Chauí (idem) formação refere-se a determinações econômicas, sociais e políticas que produzem os acontecimentos históricos, mas também a continuidade ou descontinuidade dos processos temporais, seria "a história propriamente dita, aí incluídas as representações, sejam aquelas que conhecem o processo histórico, sejam as que ocultam (isto é as ideologias).".

Assim as ideologias que necessariamente acompanham 0 movimento histórico da formação, alimentam-se das representações produzidas pela fundação, atualizando-as para adequá-las à nova quadra histórica. É exatamente por isso que, sob novas roupagens, o mito pode repertir-se indefinidamente. (CHAUI, ibidem, p. 10)

Para o geógrafo Moraes (idem, p. formação é a unidade dialética entre forma e processo que envolve a espacialidade das determinações econômica, social e política, desenhando-se desse modo como objeto empírico da relação sociedade-espaço. Envolve representações, discursos consciências e articulações práticas. Epistemologicamente a noção de formação "transita da vaga categoria de espaço ao preciso conceito de território". Este definido pelo uso social que the é conferido, sendo impossível formulá-lo sem o recurso de um grupo social que o ocupe, use ou lhe dê significação.

Nesta concepção pode-se entender o território, como dimensão espacial do Estado formado por distintas espacialidades: econômica, política, social, cultural, ambiental, que se expressam material e imaterialmente. O território usado por grupos sociais de maneira diferente e desigual, não deve ser entendido apenas como localização e/ou ocupação do espaço territorial, mas principalmente, como situação, ou estado de grupo social, em relação aos demais grupos existentes e ao próprio território e suas espacialidades. Portanto como situações, econômica, 
política, social, cultural, e estados, de pobreza, riqueza e desenvolvimento humano que dão conformação físico-territorial e sócio-geográfica ao território.

A análise detalhada da formação em suas espacialidades, isoladamente ou em conjunto, permite avaliar a natureza, a qualidade, a intensidade e dinâmica das desigualdades de um país, como também, se houver, desigualdades raciais de um modo mais específico. Como exemplo, pode-se comparar mapas e indicadores tematicamente iguais, expressando situações diferentes e desiguais para negros e brancos.

Para Marx (1996, p. 19) entender a construção da dominação racial exige um esforço grande em estabelecer limites bem definidos entre história, diferenças físicas e desenvolvimento econômico. Porém para este autor é na política do Estado, - ou na ausência de política - que as vantagens de um grupo sobre outro encontram respaldo para ampliação.

Para Boaventura de Sousa Santos, o Estado como paradigma da modernidade converge e se reduz ao desenvolvimento capitalista, onde as sociedades modernas passam a viver a contradição entre os princípios de emancipação, igualdade e integração, pelo tabalho. E os princípios de regulação desigualdade e exclusão para o trabalho. Ambos produzidos pelo próprio desenvolvimento capitalista, de quem o Estado é agente regulador, formulador e executor de políticas, mediadoras de conflitos e antagonismos.

A desigualdade é um fenômeno sócio-econômico, a exclusão é sobretudo um fenômeno social, um fenômeno de civilização. Trata-se de um processo histórico através do qual uma cultura, por via de um discurso de verdade, cria a interjeição social e a rejeição do outro, como no caso do racismo, onde se combinam dispositivos de desigualdade e exclusão, originários das práticas sociais, das ideologias e das atitudes que envolvem desenvolvimento (economia) e civilização (cultura). 
Dessa forma parece oportuno qualificarmos o racismo em dois tipos, o racismo individual e o racismo institucional.

...o racismo individual [...] sugere uma crença na superioridade da nossa raça com relação a outra, bem como as sanções e comportamentais que mantêm tais posições de superiores e inferiores [...] o racismo institucional tem dois sentidos; em primeiro lugar, é a extensão institucional de crenças racistas individuais, isto consiste, fundamentalmente, do emprego e manutenção de instituições devidamente constituídas, a fim de manter uma vantagem racista com relação a outros. Em segundo lugar, é o subproduto de algumas práticas institucionais que atuam de forma a limitar, a partir de bases raciais, as escolhas, os direitos, a mobilidade e o acesso de grupos de indivíduos a outras posições. Tais condições de desigualdade não precisam ser intencionais, mas não deixam de ser reais pelo fato de serem de facto. (JONES, 1973, p.5)

\subsection{A formação socioespacial brasileira: raça e racismo como rugosidades do espaço geográfico.}

Sabemos que no Brasil, o escravismo como expressão do capitalismo antecedeu a invenção da nação, da raça e ao próprio racismo científico. Atendeu interesses econômicos mercantis e interesses geopolíticos de uso e ocupação territorial. Sem dúvida, contribuiu também, para a delimitação territorial da nação brasileira, antes mesmo de sua existência formal como Estado independente. 
Como evento geográfico caracteriza-se por constituir-se em etapa produtiva do capitalismo mercantil que implicou na alteração da paisagem e organização espacial de três continentes, dado pelo fluxo populacional e mercantil transatlântico, pela ocupação e uso do território, pelo uso e exploração do homem - escravo negro, como mercadoria, moeda, força produtiva, meio de produção e de transformação do meio natural em meio técnico. E por último, como fato estrutural de organização social da vida brasileira.

Essas afirmações não pretendem negar o escravismo como atrocidade genocídica, etnocídica e epistemicídica de populações negras e indígenas. Porém, ao pensá-lo inicialmente à luz dos aspectos propostos, portador de lógica externa, vinculada à divisão internacional do trabalho e a sua projeção interna, a divisão territorial do trabalho, o que objetivamos é estabelecer combinações particularizadas que permita analisar os modelos cívico, cultural e político brasileiro, sistema de idéias explicativas das relações étnico-raciais atuais, estas entendidas como rugosidades, vivência social do espaço geográfico mais duradoura que os estímulos e objetivos que lhe deram origem, como alientaram (MORAES, 2002, p. 52), (SANTOS, 2002, p. 43).

Na perspectiva, das relações étnico-raciais como vivência social do espaço, o conceito de rugosidade surge como chave operacional, bastante apropriada ao enfoque das relações étnico-raciais, pois permite articular passado e presente simultaneamente, tanto na paisagem como nas configurações territoriais.

Milton Santos (Idem) usa o conceito de rugosidades em duas perspectivas uma físico-territorial, expressando uma condição material ou forma geográfica remanescente. A outra, sócio-territorial, ou sócio-geográfica, condição social presente, herança do passado, que se manifesta objetiva e subjetivamente no espaço geográfico.

Raça, classificação pela cor e racismo relação de poder são parte de um sistema de idéias acumuladas no espaço que adquirem expressão material em movimento solidário e contraditório do passado ao futuro perpetuando desigualdades sociais e materiais. 
É neste processo histórico dialético que as desigualdades étnico-raciais são reafirmadas pela negação de sua existência. Senão vejamos:

\begin{abstract}
Como as escolas procuravam uma "raça brasileira" eugenicamente perfeita, eles recompensavam certas características. Tanto alunos pobres quanto os de cor eram regularmente classificados de deficientes por diversas razões [...] à medida que as instituições educacionais trabalhavam com a pressuposição de que as crianças de cor eram desajustadas, os educadores negavam oportunidades educacionais para elas, o que por sua vez limitava o desempenho escolar do estudante e reforçava estereótipos [...] Não creio que os intelectuais e educadores desse período fossem racistas. Eles estavam tentando criar instituições públicas e inclusivas para o Brasil. Mas faziam isso dentro de valores que pressupunham que as pessoas de cor ou vivendo na pobreza não tinham capacidade de aprender, liderar ou de tomar decisão adequadas. (DÁVILLA, 2004)
\end{abstract}

A entrevista de Dávilla deixa explicito que no passado a escola não é entendida como lugar de "pessoas de cor", - negros - isto, devido há uma crença geral da incapacidade genética desse grupo. E deixa também dúvidas em relação aos intelectuais brasileiros serem racistas ou produto do tempo em que viveram.

Independente de terem sido ou não conscientemente racistas, nada muda as conseqüências danosas da falsa crença na inferioridade intelectual dos negros e o fato dessa crença ter se incorporado consciente e inconscientemente como comportamento social entre pobres e ricos, homens e mulheres, adultos e crianças, brancos e negros indistintamente.

Desde então a interjeição do negro dada pelo racismo se incorporou socioculturalmente como mentalidade e vem se reproduzindo em comportamentos e práticas racistas, muitas vezes imperceptíveis para quem as pratica, mas nem por isso menos eficientes, ao ponto de produzirem discriminações excludentes, muitas vezes também imperceptíveis às suas vítimas mais diretas. 
Se contextualizarmos a falsa crença, fruto de uma ideologia racial para os dias de hoje, considerando as reivindicações do movimento social negro, por cota ou ação afirmativa, no âmbito do ensino público superior veremos que a resistência de boa parte das universidades públicas, em tornar essas reivindicações, políticas públicas inclusivas, ampara-se, ainda que por outros argumentos, em crenças de natureza racial, não mais biológicas, mas sociologicamente racializada, pois nega-se oportunidade aos negros, em nome de um hipotético constrangimento sócio-racial de que seriam vítimas. Argumentam que se sabe hoje da igual capacidade de negros e brancos, portanto não necessidade de medidas específicas.

O paradoxo dessa argumentação é que embora reconheçam a igual capacidade intelectual do negro, temem que o ingresso desse segmento no ensino público superior promova a perda da excelência acadêmica.

Seja pela negação do passado ou pela admissão do presente o que chama a atenção é a indisposição das universidades públicas em apresentar propostas que oportunizem acesso, sugerindo que a re-elaboração atual do discurso sobre o negro é um aprimoramento do racismo, como prática excludente, que tem como propósito a defesa do espaço social conquistado pelos grupos sociais que tradicionalmente vêm ocupando as universidades públicas, ainda que inconscientemente como afirmou Dávilla.

Mantém-se a lógica formal e excludente do racismo do passado, porém de conteúdo novo, modificado pelo presente. O tempo passa a rugosidade espacial permanece.

"A cada evento, a forma se recria. Assim a forma-conteúdo não pode ser considerada apenas como forma, nem apenas como conteúdo. Ela significa que o evento, para se realizar, encaixa-se na forma disponível mais adequada a que se realizam as funções de que ele é portador" (SANTOS, 1996, p.83: apud. CLAVAL, 2004, p.26.) 
Ao conceber raça como rugosidade físico-territorial, concreção objetiva, definida pela forma cor da pele, traço imutável de diferenciação entre indivíduos brancos e não-brancos. E racismo como rugosidade sócio-territorial ou sóciogeográfica, relação hierarquizada de desigualdade e exclusão estamos propondo espacializar em diferentes períodos as mudanças ocorridas dentro dos sistemas técnicos, educacional, ocupacional e o de saúde, seus re-arranjos espaciais e reelaborações conceituais que em sociedades capitalistas, e, na brasileira em especial, se manifesta pela interjeição velada do diferente.

A questão, não consiste em ser negro, mas sim, o que isso representa em termos establishment, em outras palavras; de um lado a ameaça de divisão no atual status quo branco; e de outro a manutenção do legado de privações materiais e humilhações sociais que se renovam continuamente. Uma situação presente de desigualdade e exclusão, herdada de relações sociais pretéritas, como o colonialismo e o escravismo em escala mundial e as ideologias raciais na escala nacional e dos indivíduos.

Para Guimarães (2005, p.48-9) o Brasil se assenta sobre dicotomias que por três séculos sustentaram a ordem escravocrata, elite/povo, brancos/negros que se reforçam mútua, simbólica e materialmente. Esse sistema de hierarquização social consiste em gradações de prestígio formadas por classe social (ocupação e renda), origem familiar, cor e educação formal. A cor passa a ser uma marca de origem para um código cifrado em "raça"

A cor é uma característica objetiva do corpo da qual não se escapa. O corpo negro historicamente está investido de uma categorização racializada de valor negativo. Nesse sentido o corpo assume a condição físico-territorial de forma e sócio-geográfica de processo social.

Para Geiger, (2003, p.7) a forma é resultante do processo social que define os limites e as possibilidades de cada objeto ou indivíduo, além de permitir distingui-los. A cor como limite ou como possibilidades de vida é uma variável do processo social ideologizado pelo branqueamento da população. 
[...] No Brasil, onde a cidadania é geralmente, mutilada, o caso dos negros é emblemático. Os interesses cristalizados, que produziram convicções escravocratas arraigadas, mantêm os estereótipos, que não ficam no simbólico, incidindo sobre as demais relações sociais. $\mathrm{Na}$ esfera pública, o corpo acaba por ter um peso maior do que o espírito na formação da socialidade e sociabilidade. [...] o objetivo do produtor de eventos era a utilização do meu corpo como negro - imagem fácil - e não as minhas aquisições intelectuais, após uma vida longa e produtiva

Sem dúvida, o homem é seu corpo, a sua consciência, a sua sociabilidade, o que inclui sua cidadania. Mas a conquista, por cada um, da consciência não suprime a realidade social de seu corpo nem the amplia a efetividade da cidadania. Talvez seja essa uma das razões pelas quais, no Brasil, o debate sobre os negros é prisioneiro de uma ética enviesada. E esta seria mais uma manifestação da ambigüidade a que já nos referimos, cuja primeira conseqüência é esvaziar o debate de sua gravidade e de seu conteúdo nacional. (SANTOS, 2002a, p. 160)

A cor preta opera simultaneamente como rugosidade físico-territorial, pois é uma característica física que objetivamente, distingue na paisagem e nos espaços sociais, os negros dos não-negros, permitindo uma discriminação também objetiva manifestada pelo preconceito individual, daí os sucessivos constrangimentos sofridos por negros em espaços públicos e privados, escolas, hospitais, delegacias, mas também lojas, bancos, shoppings, prédios, clubes etc.

E como rugosidade sócio-geográfica ou sócio-territorial, pois implica em relação social ideologicamente hierarquizada pelo preconceito racial e pelo racismo institucional que consiste na manipulação "deliberada" das instituições, como extensão do pensamento racista individual. Isto gera uma situação estrutural e cumulativa, em que o progresso do país não representa melhoria efetiva correspondente à situação dos negros enquanto grupo social como assinalaram Hasenbalg \& Valle e Silva (1988) e Santos (1996/1997). 


\subsection{Políticas estatais de dominação racial: os sistemas técnicos e suas espacialidades.}

Estamos propondo uma visão sistêmica das estruturas sociais brasileiras com o propósito de não perdermos de vista a totalidade social da qual cada sistema técnico é parte. Cada sistema é parte elementar das relações sociais, jurídicas, políticas e de representações ideológicas que compõem o Estado de onde emanam como organização social.

Embora o racismo brasileiro nunca fosse legalmente institucionalizado, inúmeras foram as ações do Estado brasileiro que caminharam na direção de conservação da ordem racial hierárquica herdada do escravismo colonial. Uma delas foi o sistema eleitoral brasileiro, onde não havia explicitamente disposto pela Constituição de 1824, proibição ao voto escravo, no entanto, as condições exigidas para ser votante ou eleitor eram quase impossíveis de serem alcançadas por uma pessoa negra, ser liberto, alfabetizado e detentor de renda anual acima de 100 mil réis para votante e de 200 mil réis para eleitor, entre 1824 e 1846 , passando depois desse ano para 200 mil réis para votante a 400 mil réis para eleitor.

Dessa forma não se institucionaliza formalmente a discriminação, mas discrimina-se informalmente, através de exigências que não podem ser atendidas por um grande número de pretos e mestiços, nos primeiros anos do século $\mathrm{XX}$, maioria absoluta entre a população do país.

Outra política estatal de dominação racial foi o recenseamento, que entre 1900 a 1930 ignorou o item raça da coleta censitária oficial. A retirada coincidiu com o período mais intenso da imigração européia e do debate sobre as estratégias para promoção do branqueamento do Brasil. Essa omissão do item raça/cor dos indicadores demográficos confirmava a estratégia de divulgar externamente os avanços da política oficial de branqueamento do país ${ }^{14}$.

\footnotetext{
${ }^{14}$ A participação de João Batista de Lacerda, como representante brasileiro no I Congresso Universal das Raças, em Londres, no ano de 1911, ilustra a obsessão brasileira em parecer branca aos olhos europeus.
} 
Entre 1940 e 1950, o item cor reaparece na coleta, desagregada para todos os quesitos da população, a categoria parda é criada a posteriori e as cores são auto e hetero-declaradas. Oficialmente a categoria parda é incluída entre as demais categorias, permanecendo, até o último censo realizado em 2000.

Os censos de 40 e de 50 serviram de evidência empírica as contundentes criticas a democracia racial brasileira, emitidas por intelectuais como Thales de Azevedo, Florestan Fernandes e por lideranças do MN. A contestação da idéia de democracia racial levou o governo militar a retirar, sem justificativa alguma, o item cor do censo de 1970. Segundo a visão militar a coleta de dados sobre raça/cor servia como ameaça a ordem social vigente, pois alimentava as críticas antibrasileiristas de intelectuais e ativistas sociais, pondo em risco a estabilidade social e o desenvolvimento, além de macular internacionalmente o país, naquilo que fazia o Brasil, positivamente diferente em relação ao mundo, sua democracia racial.

Fundamentalmente a estratégia foi a de retirar os dados, se não há dados que evidenciem as desigualdades raciais, elas não existem, há não ser na cabeça de quem não tem amor à pátria, pois como nunca antes na história do país, havia empregos para tantos, crescimento econômico, independente de se no campo ou na cidade, se preto ou branco. Revivica-se o mito da democracia e da nação diferente, que abriga todos sem distinção e preconceito.

\section{Quadro Sinótico Cor nos Recenseamentos}

Censo/Ano Características

1872 Cor para todos os quesitos, como subtópico da condição social (dividida entre livres e escravos).As cores apresentadas foram: branca, preta, parda e cabocla (para indígenas e seus descendentes).

1890 Cor para a população geral, desgaregada somente no quesito estado civil. As cores

Lacerda foi duramente criticado pela elite nacional por ter enaltecido o mulato, ao invés de nem mencioná-lo e de apresentar uma estimativa de que o Brasil levaria ainda cem anos para ter uma população de maioria branca latina. Ver Lacerda 
estabelecidas foram: branca, preta, cabocla e mestiça (cabocla e mestiça referem-se às origens, respectivamente, de indígenas e descendentes e fruto da união entre brancos e pretos).

1900

1910

1920

1930

1940

1950

1960

1970

1980

1991

2000
Não foi coletada a cor da população

Não houve recenseamento

Não foi coletada a cor da população

Não houve recenseamento

Cor desagregada para todos os quesitos da população. Termos definidores: branco, preto, pardo e amarelo. No censo de 1940 os pardos foram computados numa categoria a posteriori, tendo sido as cores auto e hetero-declaradas

Cor desagregada para todos os quesitos da população. Termos definidores: branco, preto, pardo e amarelo. A cor parda foi incluída entre as cores oficiais, e as instruções para a coleta são de auto-classificação. A partir deste ano as cores não variaram mais até o presente momento

Cor para população geral. Incluíram-se os indígenas (condição de origem), com a instrução de ser aplicada somente aos residentes em Reservas Indígenas

Cor para população geral. Incluíram-se os indígenas (condição de origem), com a instrução de ser aplicada somente aos residentes em Reservas Indígenas.

Além do Estado a construção da idéia de raça e de racismo não pode ser separada do processo de desenvolvimento econômico. Marx, (1996, p.16-7) destaca que nos Estados Unidos na África do Sul, a imigração, a industrialização e a urbanização coincidiram com o aumento da segregação que se institucionalizou formalmente nessas sociedades, na forma do Jim Crow e do Apartheid, em ambas ordens raciais, por razões socioespaciais distintas, o modelo de discriminação racial, selou um pacto entre capitalistas e trabalhadores brancos, preservando a 
unidade étnica-racial branca, acima dos antagonismos e conflitos inerentes a relação capital-trabalho, a unidade étnica-racial, se sobrepôs a lealdade de classe $^{15}$.

Já no Brasil, este autor destaca que a menor concorrência e desenvolvimento econômico explicariam a ausência de uma ordem racial formalmente discriminatória, mas destaca que embora não sendo formalmente institucionalizada, a ordem racial brasileira não foi por isso menos eficiente.

"Antes, tanto os interesses dos trabalhadores brancos como os do capital avançaram dentro da democracia racial brasileira. $\mathrm{O}$ relativo privilégio dos trabalhadores brancos foi mantido pelos salários mais elevados, sem ordem ou segregação racial oficial. Em 1960, por exemplo, na área do Rio de Janeiro, relativamente desenvolvida, enquanto a renda mensal média dos negros era de $\operatorname{Cr} \$ 5.400,00$ e a dos mulatos atingia $\operatorname{Cr} \$ 6.492,00$, a dos brancos era quase o dobro, chegando a Cr\$ 11.601, 00[...] Uma vez implantado o padrão de desigualdade, esse privilégio não precisa de uma dominação racial explicita para se manter. $O$ capital também aproveitou a mão-de-obra negra barata. Além disso, por não haver segregação oficial, os negros pobres poderiam acreditar que era possível melhorar suas condições. A imagem da tolerância racial incentivou a unidade acima das classes, a estabilidade e o crescimento; $\mathrm{e}$ isso foi feito evitando-se totalmente a dominação racial explícita e o conflito." (MARX, 1996, p.18)

Estudos mais recentes ${ }^{16}$ evidenciam as enormes desigualdades vivenciadas pelos negros em todas as esferas da vida social e material. Independente do aspecto analisado, os indicadores revelam que as desigualdades são provenientes de níveis menores de educação e consequentemente menor

\footnotetext{
${ }^{15}$ Este fato evidencia questões inter-classistas interferindo nas relações de trabalho, lançando dúvida a possibilidade revolucionária da classe trabalhadora superar os problemas da também aparece para HobsFalar dos 35 milhões de imigrantes como provável razão, o antonio sérgio que diz que é a despeito de e não apesar de, imigração o branco venceu isto é que prova o preconceito de cor

${ }^{16}$ Listar alguns deles
} 
qualificação profissional, do grupo social negro, bem como, da discriminação racial, promotora de desigualdade socioeconômica e exclusão sócio-cultural.

Hasenbalg \& Valle Silva, nos anos 80 demonstraram através da análise minuciosa das estatísticas baseadas em censos oficiais e na Pesquisa Nacional de Amostragem Domiciliar, o que a Frente Negra Brasileira, nos anos 30 . E o Movimento Negro Unificado, nos anos 70 cotidianamente sabiam, que apesar do crescimento econômico que marcou a segunda metade do século $X X$, as desigualdades econômicas e sociais entre brasileiros brancos e não brancos não se alteraram, $\mathrm{m}$ esmo nos casos em que os negros tinham níveis competitivos de instrução e qualificação profissional, eram preteridos, em termos de ganhos e promoção no trabalho, a favor de brancos com o mesmo preparo.

É inegável que o pós-guerra no Brasil promoveu o crescimento econômico, ampliando a mobilidade ascensional, contudo as oportunidades foram desigualmente distribuídas como já dissemos a favor dos brancos.

“ ...desabam definitivamente as imagens sobre relações raciais no país vinculadas à noção de democracia racial. Caem por terra também as teorias que postulam uma diluição das diferenças raciais como efeito do desenvolvimento e da modernização; discriminação e desigualdades raciais não mais podem ser vistas como uma herança do passado escravista. [...] A cor das pessoas é um determinante importante das chances de vida, e a discriminação racial parece estar presente em todas as fases do ciclo de vida individual." (HASENBALG E SILVA, 1992, p. 113)

\section{2. - O Sistema educacional}

A educação é um componente básico na determinação de várias características socioeconômicas da população. Os atributos educacionais dos indivíduos definem, em grande medida, suas oportunidades de emprego e de 
renda, e afetam decisivamente suas condições de bem estar e sua inserção econômica, social e política.

“...a principal barreira para a integração do negro na sociedade brasileira, para o tratamento igualitário do negro na sociedade brasileira, é a educação. Isto é, na educação reside a maior barreira.[...] a discriminação entre brancos e negros pode ser praticamente desfeita se a gente mudar a educação do país, ou seja, a maior parte das desigualdades esta embutida no sistema educacional. (GUIMARÃES, 2002, p. 8)

Também para Martins a educação é o pressuposto de uma sociedade igualitária, não existindo igualdade com grandes disparidade educacionais, da mesma forma não existindo sociedade desigual sem que as disparidades educacionais não estejam fortemente presentes.

Para este autor o papel da educação é estratégico como determinante da distribuição de outras variáveis, em qualquer sociedade o sistema educacional pode se constituir em poderoso agente de inclusão e de promoção da igualdade, como também pode ao contrário, ser fator de geração, de manutenção e de ampliação das desigualdades e disparidades socioeconômicas.

Ainda segundo Martins, no Brasil tudo vem indicando que o sistema educacional tem se aproximado mais da segunda hipótese, pelo menos no que diz respeito às desigualdades entre as raças.

A comparação entre o número médio de anos de estudo entre brancos e negros revela uma evolução histórica com tendência de longo de prazo na discriminação como apontou (Henriques ). Embora "a escolaridade de brancos e negros aumentem de forma contínua, o jovem branco possui uma média, mais 2,3 anos de estudo que um jovem negro de mesma idade". A tendência de discriminação racial é constatada, quando se verifica que a intensidade dela foi a mesma para os seus pais e avós. 
Brasil : Número médio de anos de estudo em 1999, por coôrtes e por cor

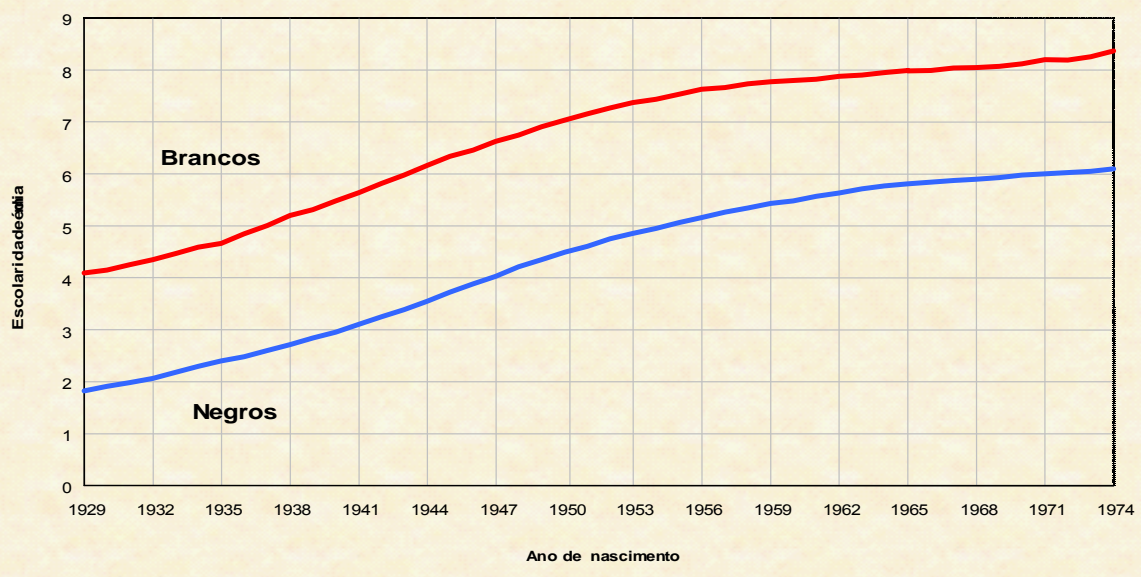

Fonte: Pesquisa Nacional por Amostra de Domicílios (PNAD) de 1999. Nota: *A população negra é œmposta por pretos e pardos.

Verifica-se que há consenso entre os autores acima, sobre a importância da educação no combate a desigualdade e para a integração do negro; que há uma maior escolaridade entre brancos; e da existência de discriminação racial perpetuando a desigualdade entre brancos e negros. Também existe o consenso de que das três; acabar com a discriminação racial é a tarefa mais difícil, isto porque ela se localiza nos interstícios do racismo individual e do racismo institucional, envolvendo questões econômicas (trunfos) e questões culturais (preconceitos).

Assim antes de apresentarmos dados estatísticos sobre brancos e negros que evidenciam diferentes espacialidades dentro de uma mesma estrutura socioespacial faremos um breve histórico da educação no Brasil tentando indicar fatores externos e internos ao grupo sócio-racial negro que impõem essa situação de desigualdade escolar.

Embora seja possível estabelecer periodizações mais precisas sobre a educação no Brasil o ano de 1930 foi escolhido por ser oficialmente o momento final da educação orientada para a formação literária e clássica e início de um projeto de educação vinculado ao desenvolvimento econômico do país, de orientação educacional técnica e científica. 
O ano de 1930 é o de criação do Ministério da Educação e Saúde e a educação é assumida como política nacional e oficial e tem entre seus objetivos expandir a rede escolar e aumentar o número de matrículas. Em 1932 o Manifesto dos Pioneiros da Educação Nova, consolida essa tendência renovadora, apontando a primazia que deveria ser dada à educação entrelaçando-a a primazia das reformas econômicas nos planos de reconstrução da nação, onde a educação se colocava "a altura das necessidades modernas e das necessidades do país" em razão da nova realidade industrial em curso.

Entre as finalidades da educação nova estão a reorientação da educação clássica e literária e do seu "sentido aristológico" deixando de se constituir em

"...privilégio determinado pela condição econômica e social do indivíduo, para assumir um "caráter biológico", com que ela se organiza para a coletividade em geral, reconhecendo a todo indivíduo o direito a ser educado até onde $\mathrm{o}$ permitam as suas aptidões naturais independentes de razões de ordem econômica e social. A educação nova, alargando a sua finalidade para além dos limites das classes, assume, com uma feição mais humana, a sua verdadeira função social, preparando-se para formar "a hierarquia democrática" pela "hierarquia das capacidades", recrutadas em todos grupos sociais, a que se abrem as mesmas oportunidades de educação." (Manifesto dos Pioneiros da Educação Nova - 1932)

Implicitamente evidencia-se aspectos biológicos de darwinismo social fundamentado nas finalidades renovadoras da educação nova. Vale a pena destacar que uma das recomendações da educação nova era equipar o Ministério da Educação e Saúde com órgãos dotados de dar capacidade científica às questões da educação brasileira, prontos a elaborar uma "política educacional e nacional solidamente alicerçada na razão, técnica e ciência e, não mais procedendo de forma improvisada". (Gandini, 1995, p.61)

Esse cientificismo de natureza biológica da educação nova pode ser comprovado pelos estudos de Dávilla (idem) que afirma ser o sistema educacional 
do Distrito Federal, - o maior do Brasil - entre 1931 e 1934, um grande laboratório de experiências eugênicas.

...Os eugenistas tiveram acesso a quase 100 mil alunos e suas fichas de saúde e de higiene mental. O sistema de educação de Teixeira era o laboratório para compreensão da natureza da degeneração e os passos para a criação da "raça brasileira". Até onde sei, o sistema escolar do Rio produziu mais pesquisa eugênica do que qualquer outra instituição da era Vargas.

[...] A pesquisa era bastante ampla, variando da higiene dental e estudos de nutrição para as análises de mistura racial entre os estudantes. O estudo mais importante a ser publicado dessa pesquisa foi "A Criança Problema", do [antropólogo] Arthur Ramos, que examinava problemas psicológicos e culturais. Os anais do Primeiro Congresso Afro-Brasileiro, organizado em 1934 por Gilberto Freyre, mostram uma grande participação de pesquisadores empregados por Teixeira - incluindo o biometrista Bastos d' Ávila, que apresentou resultados do "índice de Lapique", que supostamente permitia determinar por meio de medidas biométricas a presença de ancestralidade negra entre pessoas que pareciam brancas.

Dávila conclui a entrevista apontando para uma conclusão que vai de encontro com a principal hipótese desse capítulo que é o de institucionalização de valores raciais em diversas áreas das chamadas políticas sociais. Esses valores são expressos pelo caráter biológico definidor de aptidões naturais, que para a educação nova são vistos em termos de ampliação às determinações socioeconômicas impostas as classes mais baixas. No entanto e, paradoxalmente, essa renovação da educação como parte do projeto de reconstrução da nação é tanto progressista, quanto preconceituosa. Amplia-se as oportunidades para as classes menos abastadas, porém com ressalva biológica, as aptidões de negros e mestiços, tidos pela sociedade como excessivamente frágeis para o aprendizado. 
No caso específico da educação a tese eugênica equiparou branquitude a saúde e moldou um preconceito racial que se expandiu para currículos, programas e materiais pedagógicos. Estudos recentes do Saeb revelam que alunos negros abandonam prematuramente a escola por razões de natureza socioeconômica, mas também pela reprodução de práticas discriminatórias contra alunos negros, configurando um ambiente escolar de hostilidade. Qual outra explicação para que mesmo em escolas particulares ocorra desigualdades de desempenho entre negros e brancos, filhos de pais de mesma escolaridade?

Muitas são os estudos sobre a representação do negro nos livros didáticos, Rosemberg (1980), Pahim (1981), Pretto (1983) Gonçalves (1985) Negrão (1986, 1990), Silva (1986), Silva (1988 e 2001), de uma forma geral todos concluem haver sobre o negro uma representação estigmatizada e estereotipada que afeta a auto-estima da criança negra interferindo em seu desempenho escolar.

Para além de conteúdos e métodos, Cavalleiro (1998), Botelho (2000) Abramoway (2003) investigaram a relação entre professores e alunos, entre alunos, entre famílias e as escolas concluindo a presença de discriminações entre e intra grupo. A comparação dos perfis de escolaridade de negros e brancos demonstra acima de qualquer dúvida a incapacidade até o momento do sistema educacional superar ou, pelo menos, minimizar as imensas iniqüidades geradas tanto pela exclusão escravista, como pelas discriminações raciais. 


\section{Gráfico 2}

TAXA DE ANALFABETISMO, POR RAÇA E FAIXA ETÁRIA, 1992

Taxa de analfabetismo, por raça e faixa etária, 1992

Fonte: PEA, com base na PNAD, IBGE

em porcentagem da população total da faixa

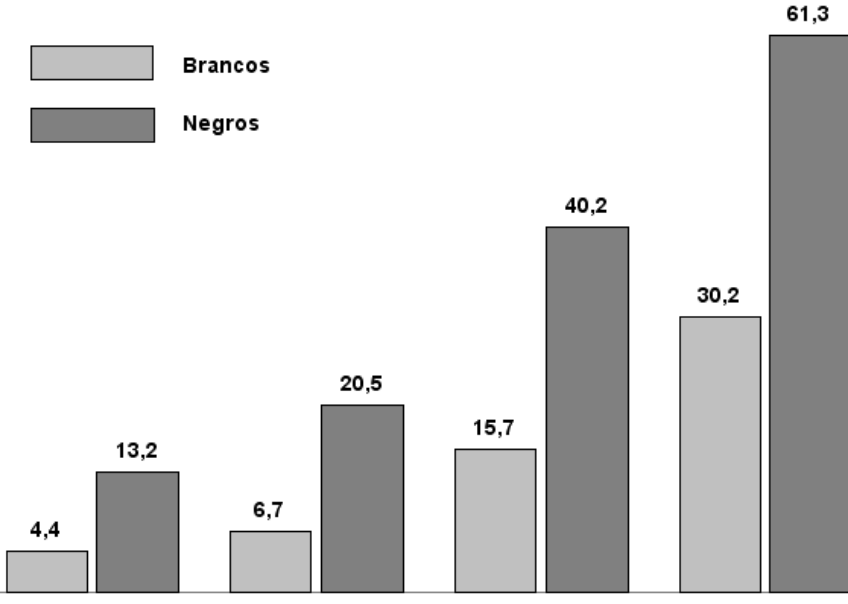

60 ou mais

25,7

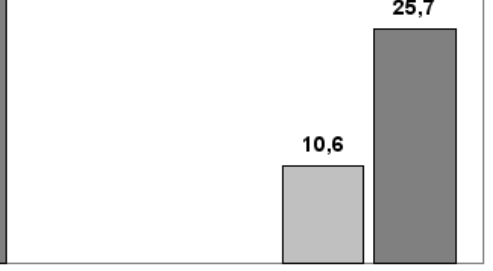

15 ou mais

Fonte: IPEA, com base na PNAD, IBGE

Gráfico 3 
Perfil educacional da população de 25 anos ou mais, por raça, 1992

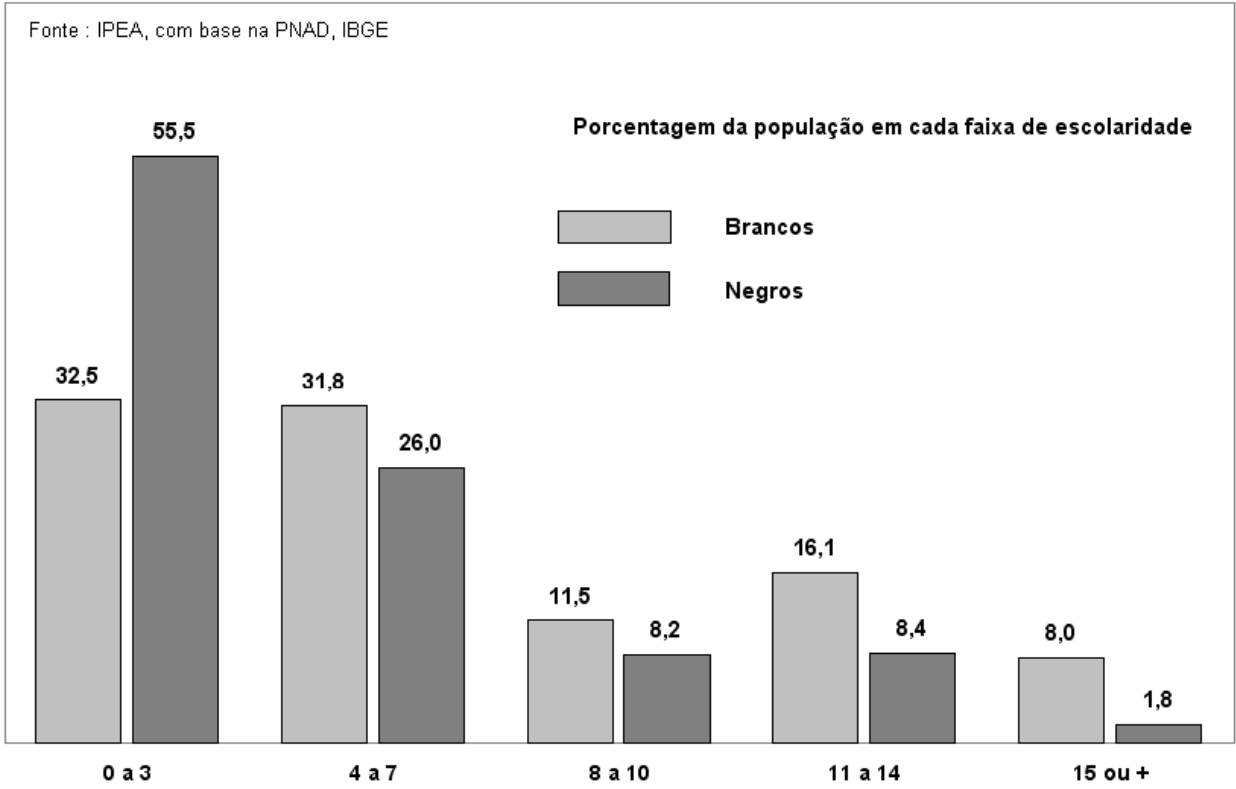

Fonte: IPEA, com base na PNAD, IBGE

No início da década de 90 as taxas de analfabetismo da população negra se situavam em patamares duas ou três vezes mais altos que as da população branca, atingindo na faixa mais jovem (15 a 24 anos), o triplo da taxa dos brancos. No conjunto da população de 15 anos ou mais, mais de $25 \%$ dos negros eram analfabetos (contra cerca de $10 \%$ dos brancos). Mais da metade da população negra adulta (25 anos ou mais) tinha menos de 4 anos de estudo, situando-se, portanto, na categoria de analfabetos funcionais; $82 \%$ (contra menos de 2/3 dos brancos) não havia completado o primeiro grau (8 anos de estudo); e 90\% (contra $3 / 4$ dos brancos) não havia completado o ensino médio, ou segundo grau (11 anos de estudo). Menos de 2 em cada 100 negros adultos haviam completado 4 anos de ensino superior (contra $8 \%$ dos brancos). 


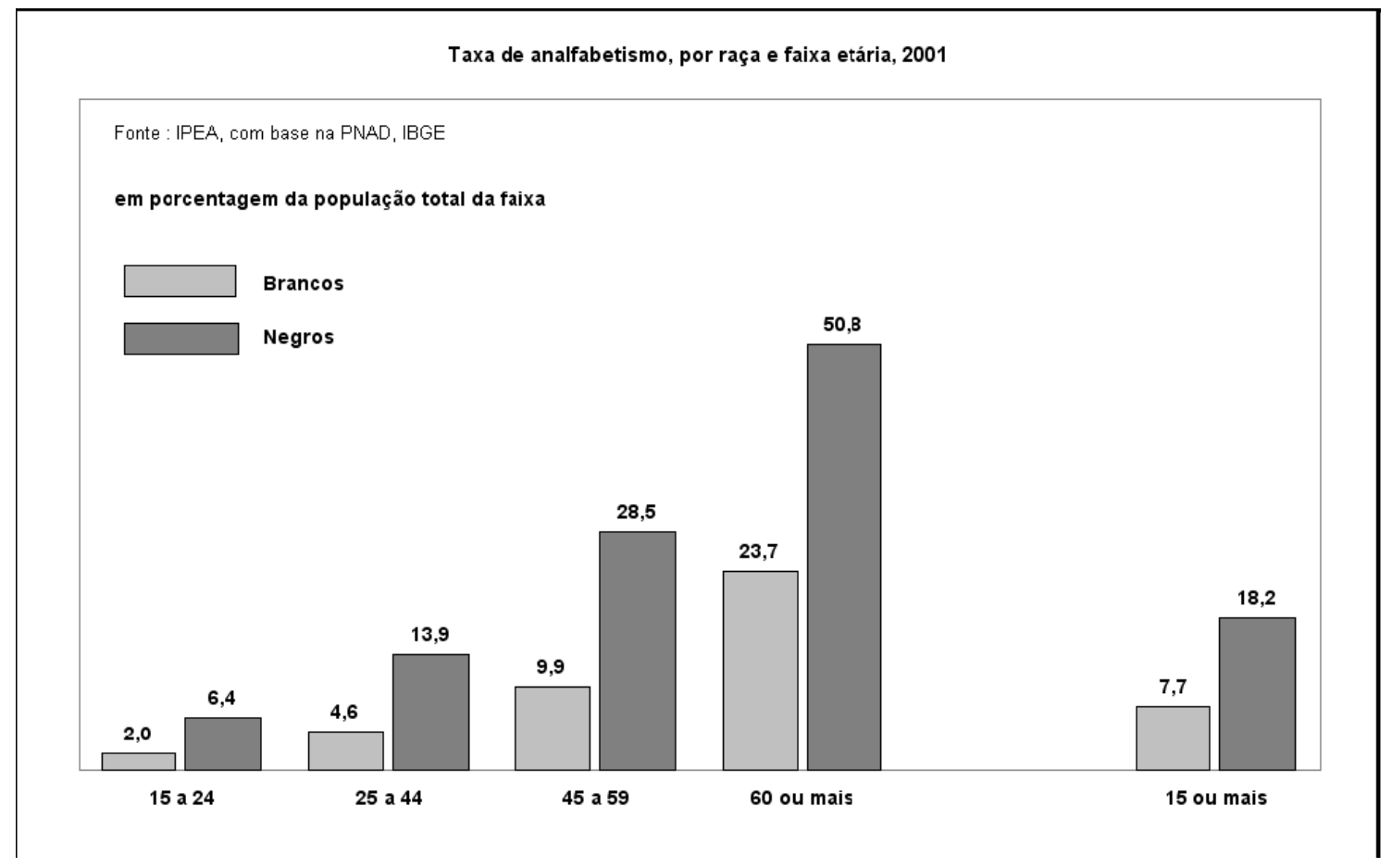

Fonte: IPEA, com base na PNAD, IBGE

A universalização do ensino na segunda metade dos anos 90, reduziu as taxas de analfabetismo da população de um modo geral e conseguiu ampliar o acesso da população a todos os níveis de ensino, melhorando estatisticamente o perfil de escolaridade do Brasil. Embora essa melhoria tenha atingido negros e brancos sem distinção, sua distribuição foi desigual, beneficiando mais a população branca que a negra. Nota-se inclusive que em alguns casos a distância existente foi ampliada. 
Perfil educacional da população de 25 anos ou mais, por raça, 2001

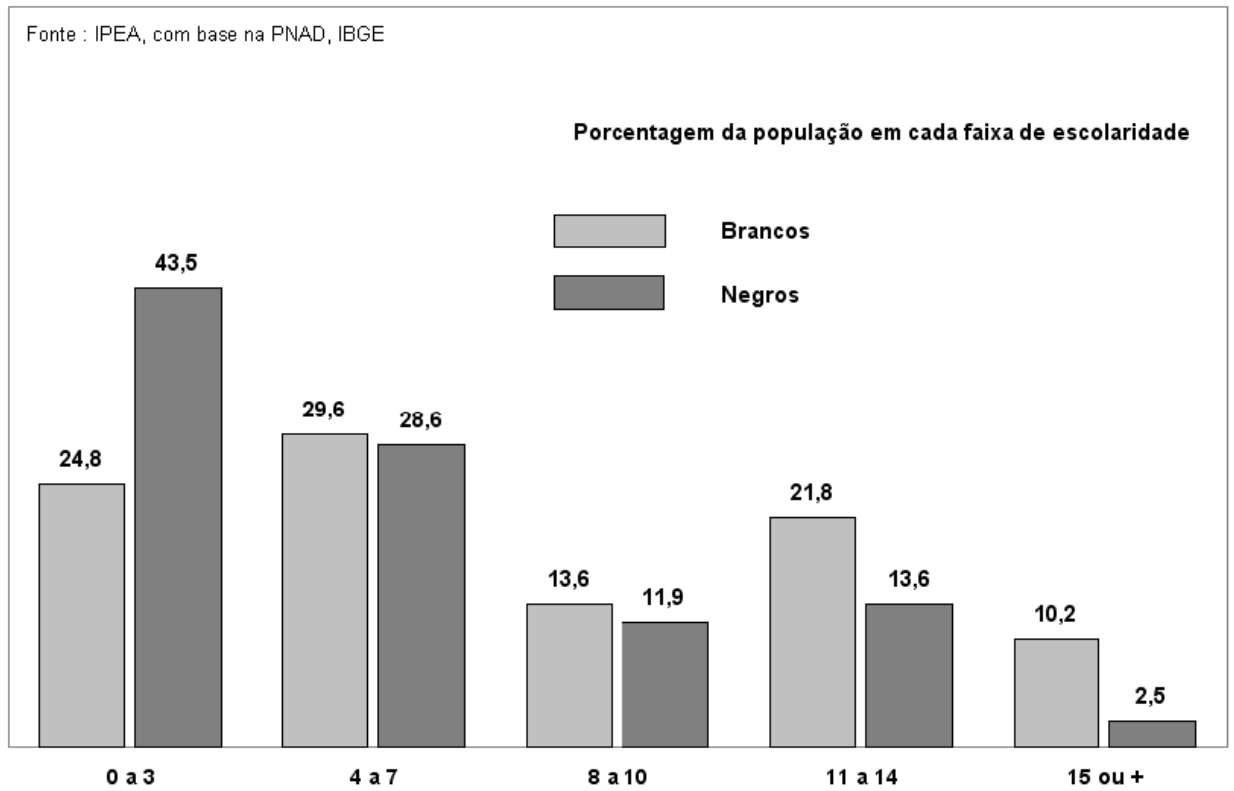

Fonte: IPEA, com base na PNAD, IBGE.

\section{Gráfico 6}

TAXA DE ANALFABETISMO (PESSOAS DE 15 A 24 ANOS), 1992-2001

Taxa de analfabetismo (pessoas de 15 a 24 anos), 1992-2001

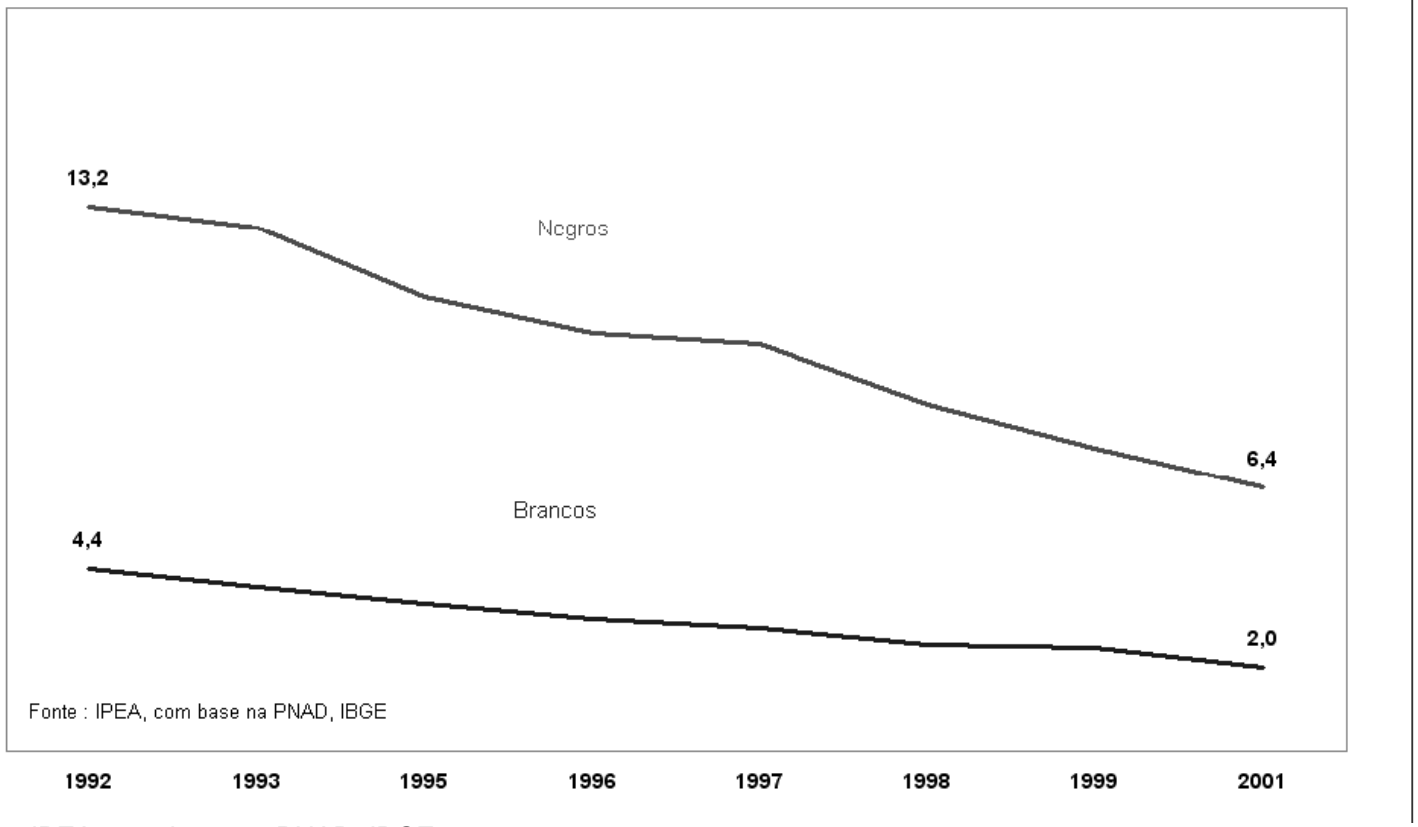

Fonte: IPEA, com base na PNAD, IBGE

Negros Brancos 
Porcentagem da população de 7 a 13 anos que não frequenta escola, 1992-2001

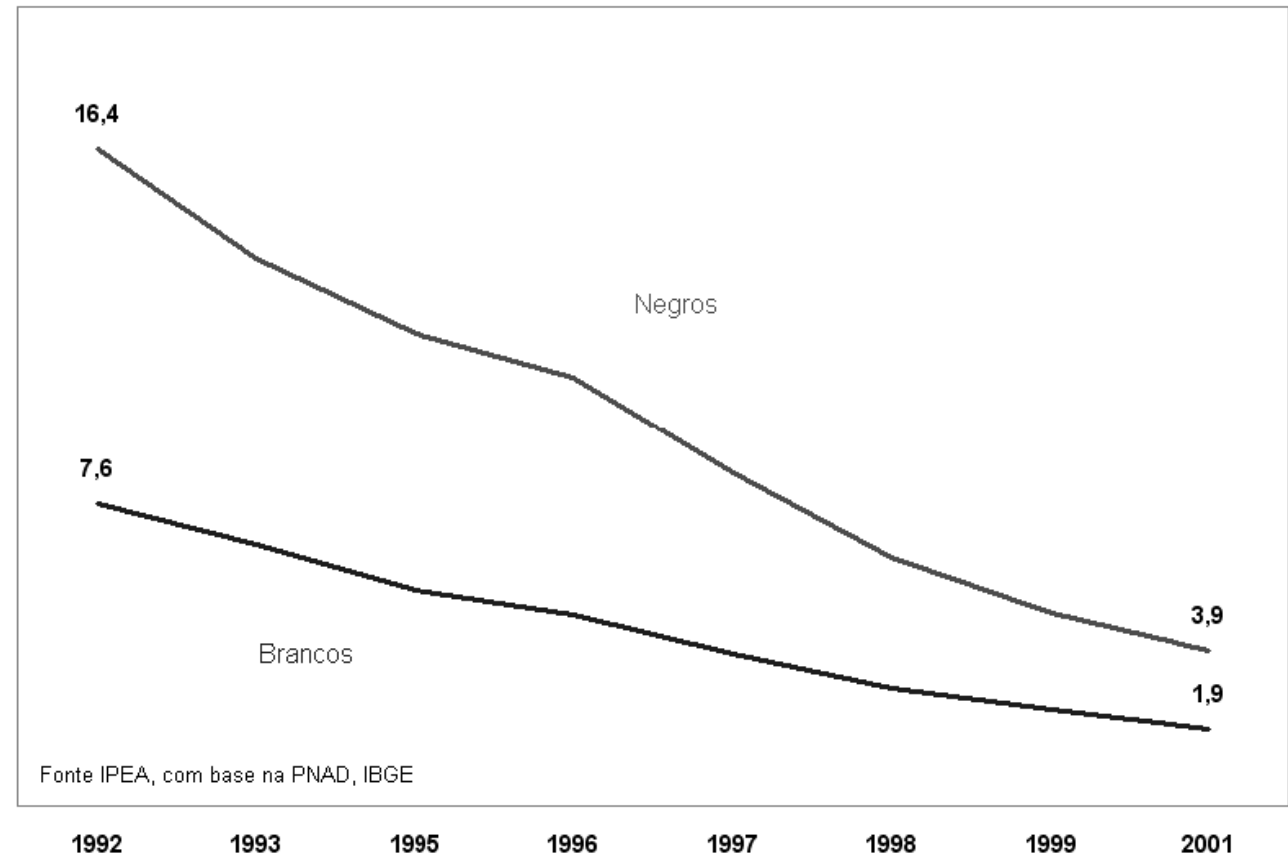

Fonte: IPEA, com base na PNAD, IBGE.

Tabela 2

PORCENTAGEM DA POPULAÇÃO DE 25 ANOS DE IDADE OU MAIS POR FAIXA DE ESCOLARIDADE, 1992-2001

\begin{tabular}{|c|c|c|c|c|c|c|c|c|}
\hline 1992 & $\begin{array}{l}\text { Menos de } 4 \\
\text { anos } \\
\text { Brancos } \\
32,5\end{array}$ & $\begin{array}{l}\text { Negros } \\
55,5\end{array}$ & $\begin{array}{l}8 \text { anos ou } \\
\text { mais } \\
\text { Brancos } \\
35,7\end{array}$ & $\begin{array}{l}\text { Negros } \\
18,4\end{array}$ & $\begin{array}{l}\mathbf{1 1} \text { anos ou } \\
\text { mais } \\
\text { Brancos } \\
24,2\end{array}$ & $\begin{array}{l}\text { Negros } \\
10,2\end{array}$ & $\begin{array}{l}\text { 15 anos ou } \\
\text { mais } \\
\text { Brancos } \\
8,0\end{array}$ & $\begin{array}{l}\text { Negros } \\
1,8\end{array}$ \\
\hline 1993 & 31,4 & 53,9 & 36,0 & 19,5 & 24,4 & 10,8 & 8,1 & 1,9 \\
\hline 1995 & 29,9 & 52,2 & 37,7 & 20,6 & 25,6 & 11,7 & 8,7 & 2,0 \\
\hline 1996 & 29,1 & 49,8 & 39,2 & 22,8 & 26,2 & 12,4 & 8,8 & 2,1 \\
\hline 1997 & 28,0 & 49,7 & 40,5 & 22,6 & 27,6 & 12,8 & 9,4 & 2,2 \\
\hline 1998 & 27,0 & 48,2 & 41,9 & 23,9 & 28,6 & 13,3 & 9,7 & 2,2 \\
\hline 1999 & 26,4 & 46,9 & 42,6 & 24,7 & 29,4 & 14,0 & 9,8 & 2,3 \\
\hline 2001 & 24,8 & 43,5 & 45,6 & 27,9 & 32,0 & 16,1 & 10,2 & 2,5 \\
\hline
\end{tabular}

Fonte: IPEA, com base na PNAD, IBGE

Nota: No sistema educacional brasileiro 8 anos correspondem ao primeiro grau completo, 11 anos correspondem ao segundo grau completo e quinze anos correspondem ao terceiro grau (universidade, no nível de graduação)

Apenas no analfabetismo jovem, onde por razões naturais e no acesso ao nível inicial de escolarização que houve alguma convergência entre os indicadores 
educacionais dos dois grupos. Nos níveis médio e superior, embora os dois grupos tenham melhorado suas posições, as diferenças não só permaneceram muito elevadas, como se ampliaram ao longo da década.

Gráfico 8

EVOLUÇÂO DO HIATO EDUCACIONAL * ENTRE BRANCOS E NEGROS, 1992-2001

Evolução do hiato educacional ${ }^{\star}$ entre brancos e negros, 1992-2001

(*) Diferença, em pontos percentuais, entre as porcentagens da populaçăo branca e da populaçẫo negra em cada faixa de escolaridade: (1) Negros menos brancos. (2) Brancos menos negros.

menos de 4 anos de estudo (1)

23

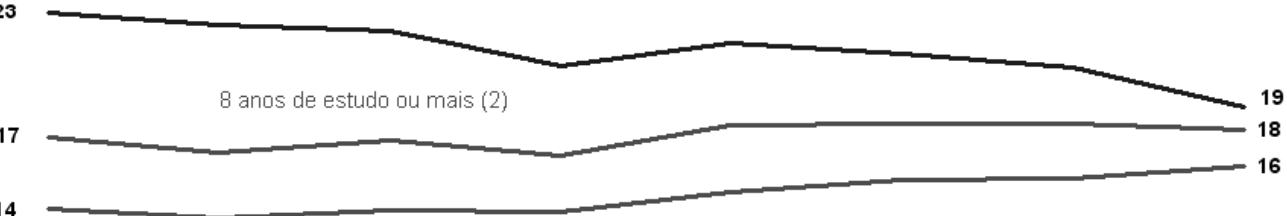

14

11 anos de estudo ou mais (2)

6

Fonte: IPEA, com base na PNAD, IBGE

1992

1993

1995

1999

2001

Fonte: IPEA, com base na PNAD, IBGE

A persistência da exclusão que incide sobre a população negra no nível superior de educação é alarmante pois significa seu virtual alijamento das ocupações de maior prestígio e remuneração, das posições de comando e deliberação, das camadas dirigentes tanto no setor público quanto no setor privado, e das atividades culturais e científicas que demandam educação formal. Com graves reflexos não só para suas condições materiais de vida, mas também para sua auto-estima e bem estar psicológico.

Vimos no Gráfico de num acima, que no início dos anos 90 apenas 1,8\% da população adulta negra tinha alcançado 15 anos ou mais de escolaridade contra $8,0 \%$ dos brancos. Ao final do período, apesar dos avanços registrados, essa porcentagem atingiu somente $2,5 \%$, contra $10,2 \%$ dos brancos. 
Gráfico 9

POPULAÇÃO UNIVERSITARIA* EM MILHARES, 1991 E 2000

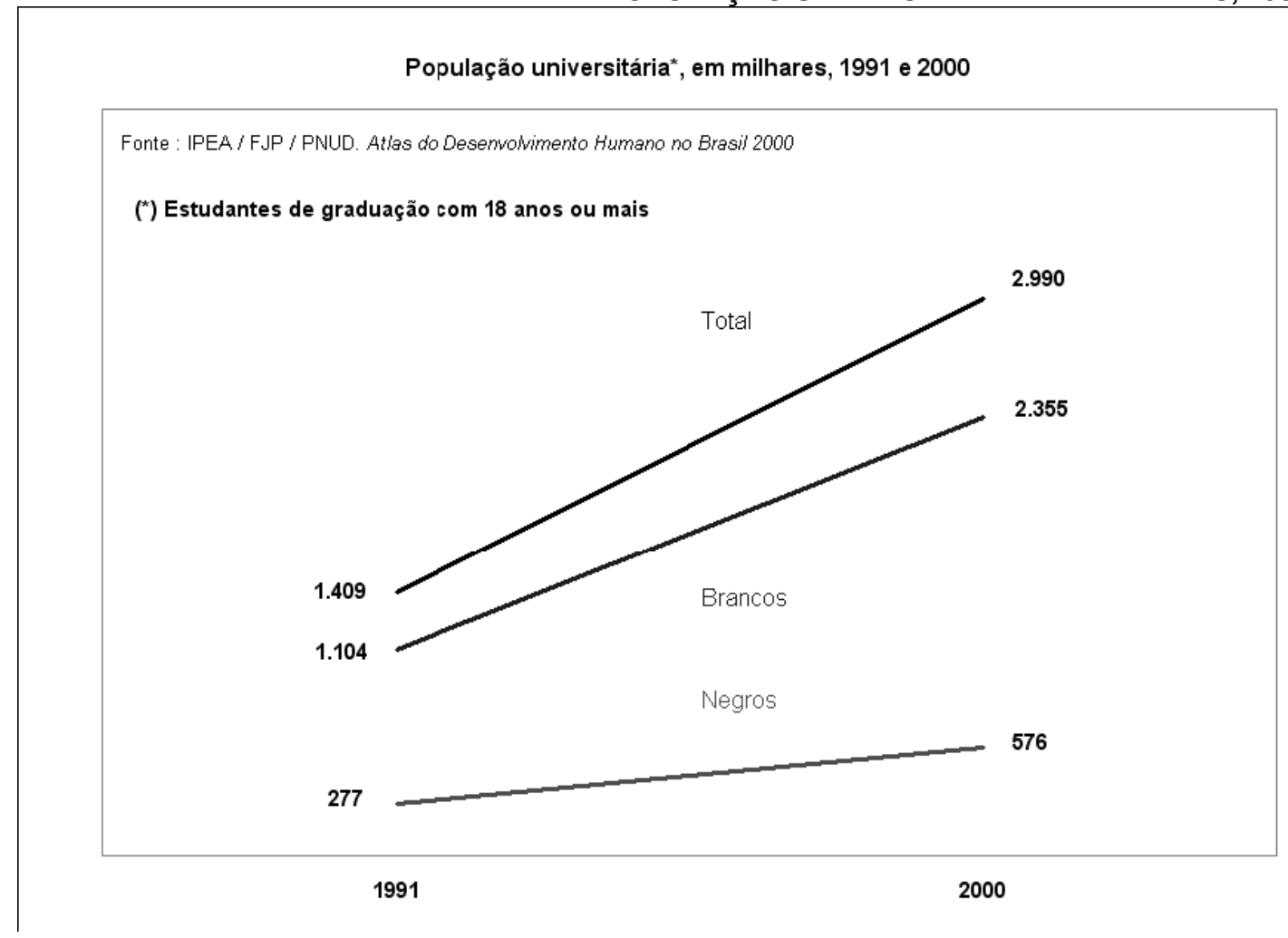

Fonte: IPEA, com base na PNAD, IBGE

O gráfico acima revela que enquanto o sistema universitário mais que dobrou passando de 1.409 milhões para quase 2.990 milhões de matriculados, a participação dos negros reduziu, de 19,7\% para 19,3\%. Considerando apenas a população de 18 a 24 anos de idade, os negros totalizam $48 \%$ da população desta faixa etária tiveram sua participação reduzida de 16,7 para 15,9\%. Essa redução ocorreu em todas as unidades da federação exceto em São Paulo, onde se manteve inalterada e no Mato Grosso do Sul, onde cresceu em menos de um ponto percentual. No período entre os dois recenseamentos, a proporção de 
jovens brancos (de 18 a 24 anos) matriculada na universidade cresceu de 7 para $11,7 \%$, enquanto a dos jovens negros se elevou em apenas 1 ponto percentual, de 1,5 para $2,5 \%$.

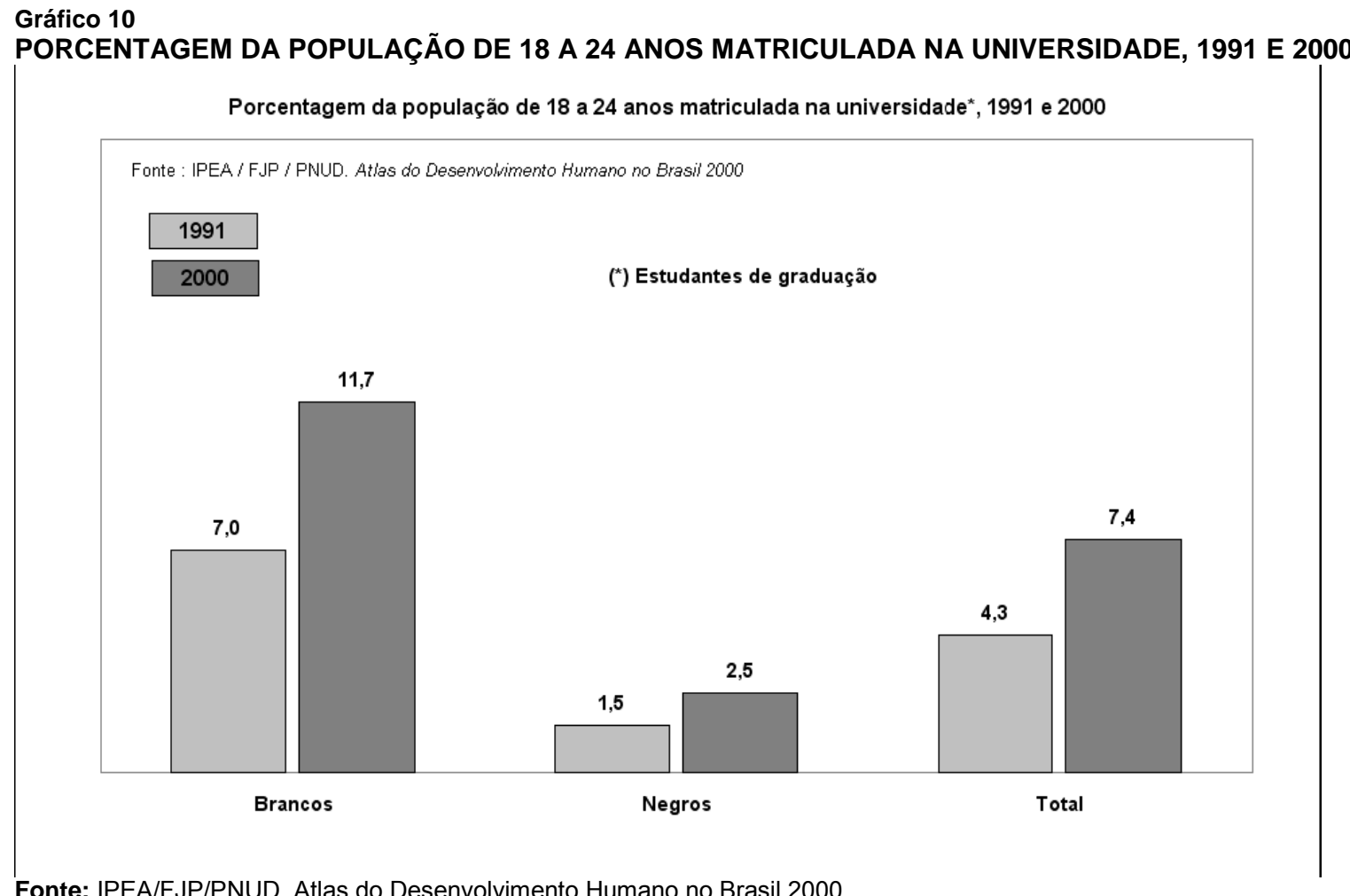

Fonte: IPEA/FJP/PNUD, Atlas do Desenvolvimento Humano no Brasil 2000 


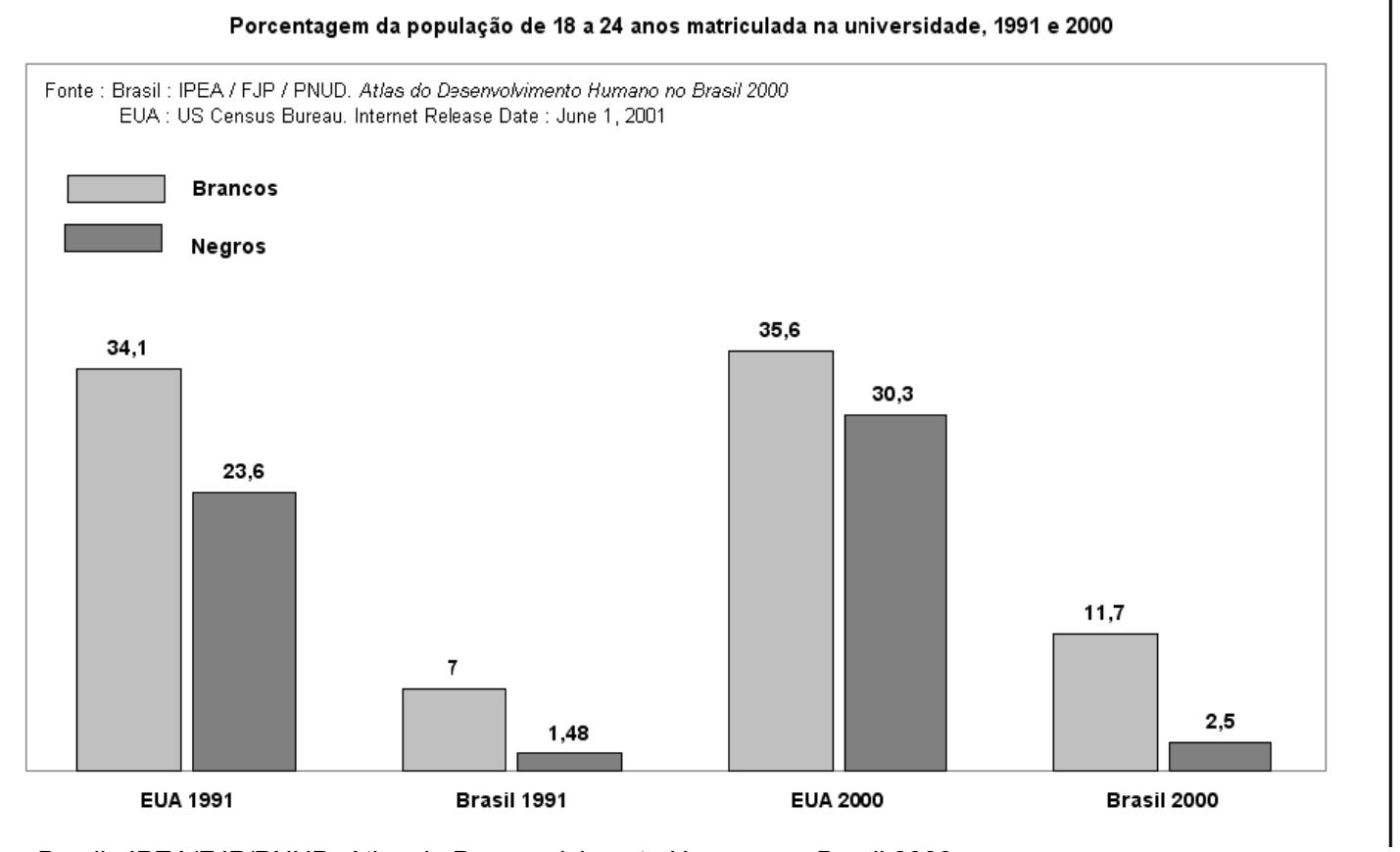

Fonte: Brasil : IPEA/FJP/PNUD, Atlas do Desenvolvimento Humano no Brasil 2000 EUA Census Bureau Internet Release Date: June 1, 2001

Além de pequena a participação de negros no ensino superior se concentra nos cursos de menor prestígio ${ }^{17}$. O nível de agregação dos dados disponíveis não nos permite enxergar o fato, evidente em qualquer campus universitário do país, de que a presença negra nas faculdades e cursos mais demandados e prestigiados, como medicina, direito e engenharia, é ainda mais rarefeita do que aquela revelada pelas estatísticas agregadas.

Outro aspecto da participação negra, porém, este de caráter especulativo, isto pela falta de pesquisa, dá conta que a participação dos negros não é ainda mais reduzida ao longo da década, porque houve expansão do sistema universitário privado. A gratuidade e a melhor qualidade das universidades públicas brasileiras acirra a disputa pelas vagas oferecidas. Em situações como essa, o histórico de discriminações da população negra pesa favoravelmente em termos de disputa de vagas, como trunfo da população branca.

Assim as piores condições de formação escolar herdada de pais e avós, a maior evasão, decorrente da necessidade de trabalhar mais cedo e de relações 
raciais preconceituosas e discriminatórias que interferem no desempenho e dificultam a permanência em ambiente escolar tendem a diminuir as chances das pessoas negras serem bem sucedidas no vestibular, até o momento única porta de acesso às universidades públicas do país e consequentemente a melhores oportunidades de trabalho.

\section{3 - O sistema ocupacional: mercado de trabalho, renda e pobreza}

Não chega causar surpresa que as disparidades já demonstradas no sistema educacional também ocorram no sistema ocupacional. A peculiaridade é que as disparidades entre os grupos raciais se repetem sem exceção dentro de cada gênero. E o hiato entre os gêneros, ocorre também da mesma forma no interior de cada grupo racial. Em outras palavras, os homens negros têm sempre taxas superiores de desemprego que às dos homens brancos, assim como as mulheres negras comparadas às mulheres brancas; as mulheres negras comparadas aos homens negros e as mulheres brancas comparadas aos homens brancos.

Gráfico 12

TAXA DE DESEMPREGO, POR GÊNERO E RAÇA, 1992-2001

Taxa desemprego, por gênero e raça, 1992-2001

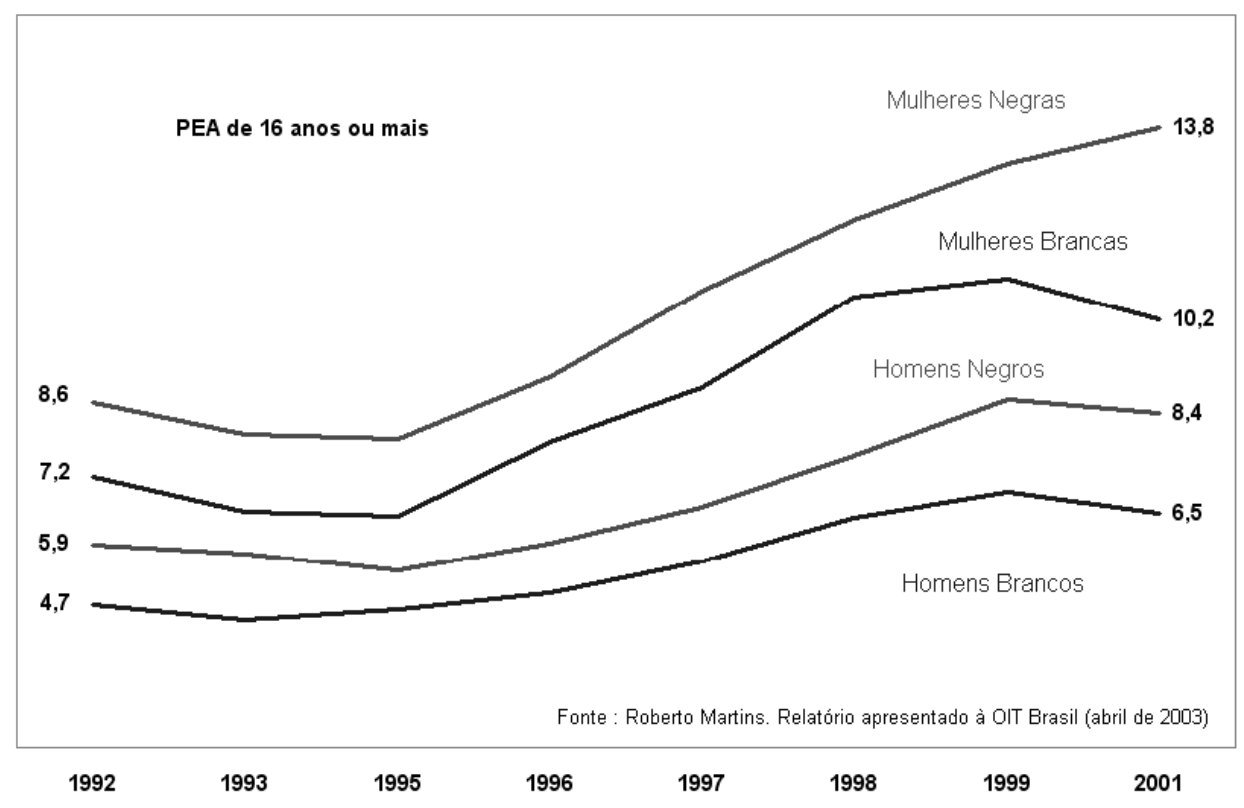

${ }^{17}$ A zana falou da pesquisa da ana lúcia 
As tabelas seguintes, referentes às faixas etárias de 16 a 24 anos e de 25 anos ou mais, demonstram que, apesar da mudança de escala (a faixa mais jovem apresentando, como seria de se esperar, taxas consideravelmente mais altas que a faixa dos adultos) a hierarquia das taxas entre homens e mulheres, brancos e negros, e em todas as combinações de raça e gênero, se mantém absolutamente intacta, em todos os anos da série.

Tabela 3

TAXA DE DESEMPREGO, POR GÊNERO E RAÇA, PEA DE 25 ANOS OU MAIS, 1992-2001

\begin{tabular}{lllllll}
\hline & $\begin{array}{l}\text { Todos } \\
\text { brancos }\end{array}$ & $\begin{array}{l}\text { Todos } \\
\text { neggros }\end{array}$ & $\begin{array}{l}\text { Homens } \\
\text { brancos }\end{array}$ & $\begin{array}{l}\text { Mulheres } \\
\text { brancas }\end{array}$ & $\begin{array}{l}\text { Homens } \\
\text { negros }\end{array}$ & $\begin{array}{l}\text { Mulheres } \\
\text { negras }\end{array}$ \\
$\mathbf{1 9 9 2}$ & 3,9 & 4,8 & 3,3 & 4,8 & 4,1 & 5,8 \\
$\mathbf{1 9 9 3}$ & 3,5 & 4,5 & 2,9 & 4,3 & 4,0 & 5,4 \\
1995 & 3,7 & 4,4 & 3,1 & 4,5 & 3,8 & 5,1 \\
1996 & 4,3 & 5,1 & 3,4 & 5,6 & 4,2 & 6,5 \\
1997 & 4,9 & 5,9 & 3,8 & 6,3 & 4,7 & 7,6 \\
1998 & 5,6 & 6,4 & 4,3 & 7,4 & 5,1 & 8,3 \\
1999 & 6,0 & 7,3 & 4,7 & 7,7 & 6,0 & 9,3 \\
$\mathbf{2 0 0 1}$ & 5,6 & 7,5 & 4,4 & 7,2 & 5,8 & 10,0
\end{tabular}

Fonte : Roberto B. Martins. Desigualdades e Discriminação de Gênero e de Raça no Mercado Brasileiro de Trabalho no final do século XX. Relatório apresentado à OIT Brasil (abril de 2003)

Tabela 4

TAXA DE DESEMPREGO, POR GÊNERO E RAÇA, PEA DE 16 A 24 ANOS, 1992-2001

\begin{tabular}{|c|c|c|c|c|c|c|}
\hline 1992 & $\begin{array}{l}\begin{array}{l}\text { Todos } \\
\text { brancos } \\
11,2\end{array} \\
\end{array}$ & $\begin{array}{l}\text { Todos } \\
\text { neggros } \\
12,3\end{array}$ & $\begin{array}{l}\text { Homens } \\
\text { brancos } \\
9,1\end{array}$ & $\begin{array}{l}\text { Mulheres } \\
\text { brancas } \\
14,1\end{array}$ & $\begin{array}{l}\text { Homens } \\
\text { negros } \\
10,2\end{array}$ & $\begin{array}{l}\text { Mulheres } \\
\text { negras } \\
15,8\end{array}$ \\
\hline 1993 & 10,9 & 11,7 & 9,2 & 13,1 & 9,8 & 14,9 \\
\hline 1995 & 10,9 & 11,8 & 9,7 & 12,7 & 9,3 & 15,9 \\
\hline 1996 & 12,0 & 12,6 & 10.0 & 14,9 & 10,2 & 16,5 \\
\hline 1997 & 13,9 & 14,5 & 11,4 & 17,2 & 11,5 & 19,5 \\
\hline 1998 & 16,6 & 17,3 & 13,3 & 21,0 & 13,8 & 23,0 \\
\hline 1999 & 17,4 & 18,9 & 14,3 & 21,4 & 15,5 & 24,4 \\
\hline 2001 & 16,4 & 19,2 & 13,6 & 19,9 & 15,4 & 25,0 \\
\hline
\end{tabular}

Fonte : Roberto B. Martins. Desigualdades e Discriminação de Gênero e de Raça no Mercado Brasileiro de Trabalho no final do século XX. Relatório apresentado à OIT Brasil (abril de 2003)

De acordo com os estudos do IPEA existe uma interação entre escolaridade e empregabilidade no Brasil dos anos 90 bastante complexa. Onde não se observa empiricamente nenhuma relação simples, direta ou inversa, entre as duas 
variáveis. O padrão que emerge dos dados da PNAD sugere que, em todos os grupos de gênero e raça e em todas as faixas etárias, a taxa de desemprego aumenta com a escolaridade até atingir um máximo na faixa de 8 a 10 anos de estudo e declina, sucessivamente, nas faixas de 11 a 14 e de 15 anos ou mais, atingindo nesta última o seu ponto mínimo.

Apesar disso, a existência de hiatos sistemáticos entre as taxas de desemprego de grupos situados nas mesmas faixas de escolaridade é significativa, sugerindo fortemente a ocorrência de discriminação racial. O padrão de hierarquização das taxas referido acima $(\mathrm{HB}<\mathrm{MB}, \mathrm{HN}<\mathrm{MN}, \mathrm{B}<\mathrm{N}, \mathrm{HB}<\mathrm{HN}$, $\mathrm{MB}<\mathrm{MN}$ ) se repete com uma regularidade impressionante, em todos os anos da série. Na tabela e no gráfico abaixo são apresentadas apenas os números referentes aos dois anos extremos, mas essa hierarquia se mantém com grande regularidade ao longo de todo o período analisado. 
TAXA DE DESEMPREGO, POR RAÇA E ESCOLARIDADE, 1992 E 2001

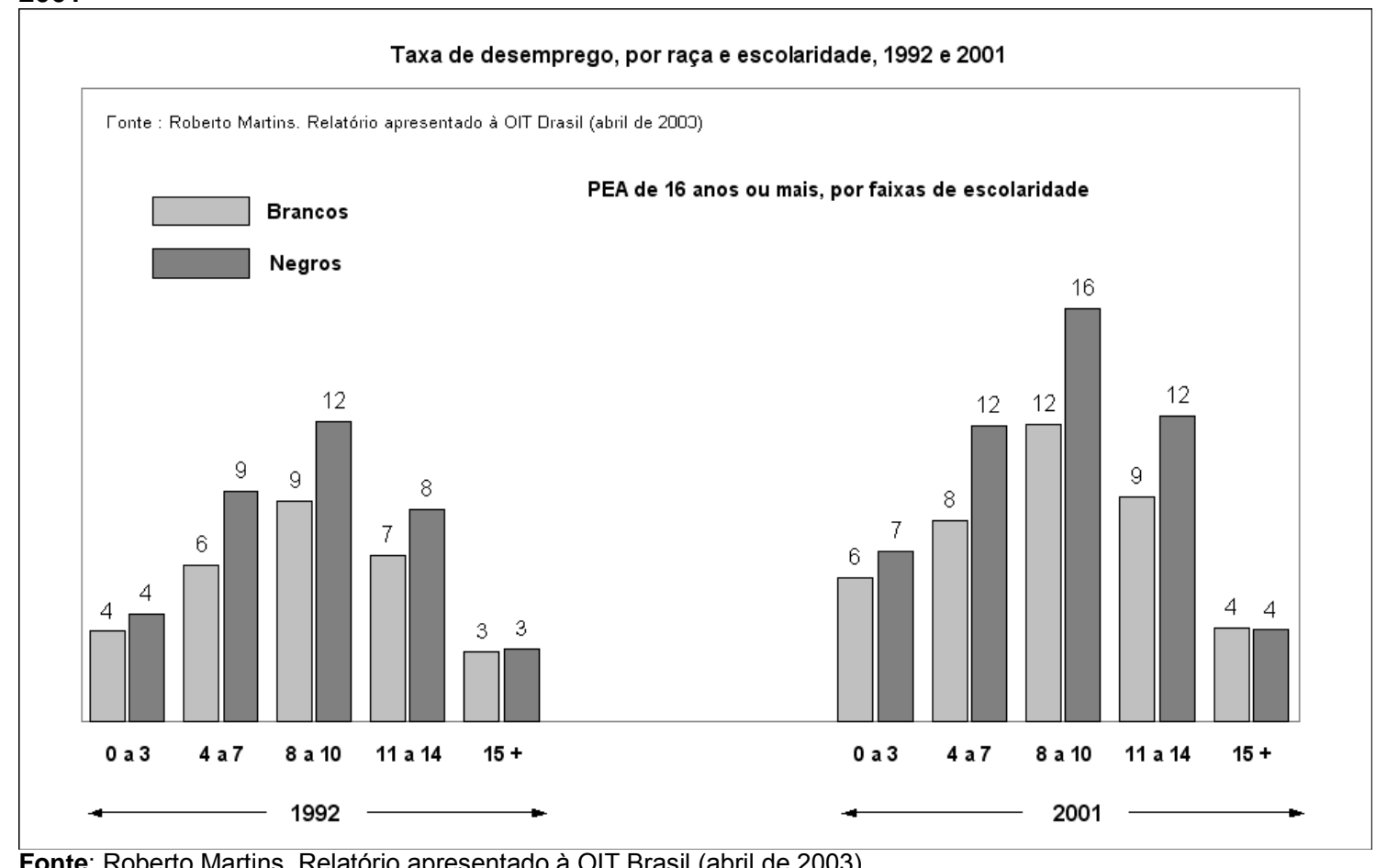

Fonte: Roberto Martins, Relatório apresentado à OIT Brasil (abril de 2003)

\subsubsection{Renda do trabalho}

Os dados do IPEA revelam que as desigualdades raciais são mais explicitas quando se examina a renda do trabalho. Pela verifica-se a magnitude e regularidade dos hiatos de remuneração. Em nenhum ano da série estudada a remuneração dos negros ultrapasa $51 \%$ da renda dos brancos. Desagregando por sexo verifica-se que a renda dos homens negros nunca alcança a metade da remuneração dos homens brancos. Entre as mulheres o hiato é ligeiramente menor, mas mesmo assim a renda média das negras não atinge mais que $53 \%$ da renda das brancas em nenhum momento.

Tabela 5 RENDA* DE TODOS OS TRABALHOS, OCUPADOS DE 16 ANOS OU MAIS, POR GÊNERO E RAÇA, 1992-2001

\begin{tabular}{lllllll}
\hline & $\begin{array}{l}\text { Todos } \\
\text { brancos }\end{array}$ & $\begin{array}{l}\text { Todos } \\
\text { neggros }\end{array}$ & $\begin{array}{l}\text { Homens } \\
\text { brancos }\end{array}$ & $\begin{array}{l}\text { Homens } \\
\text { negros }\end{array}$ & $\begin{array}{l}\text { Mulheres } \\
\text { brancas }\end{array}$ & $\begin{array}{l}\text { Mulheres } \\
\text { negras } \\
250\end{array}$ \\
1992 & 605 & 307 & 691 & 342 & 475 & 255 \\
1993 & 636 & 316 & 733 & 354 & 491 & 328 \\
1995 & 789 & 391 & 909 & 431 & 618 & 347 \\
1996 & 825 & 404 & 915 & 440 & 691 & 336 \\
1997 & 816 & 392 & 922 & 427 & 663 & 344 \\
1998 & 808 & 392 & 902 & 423 & 670 & \\
\hline
\end{tabular}




\begin{tabular}{lllllll}
\hline 1999 & 748 & 371 & 827 & 402 & 637 & 323 \\
2001 & 757 & 376 & 847 & 402 & 634 & 336 \\
\hline
\end{tabular}

Fonte : Roberto B. Martins. Desigualdades e Discriminação de Gênero e de Raça no Mercado Brasileiro de Trabalho no final do século XX. Relatório apresentado à OIT Brasil (abril de 2003).

Nota: $\left(^{*}\right)$ Renda média mensal, em reais de janeiro de 2002, padronizada para 40 horas semanais

Gráfico 14

RENDA DO TRABALHO* DOS NEGROS COMO PORCENTAGEM DOS BRANCOS, 1992-2001

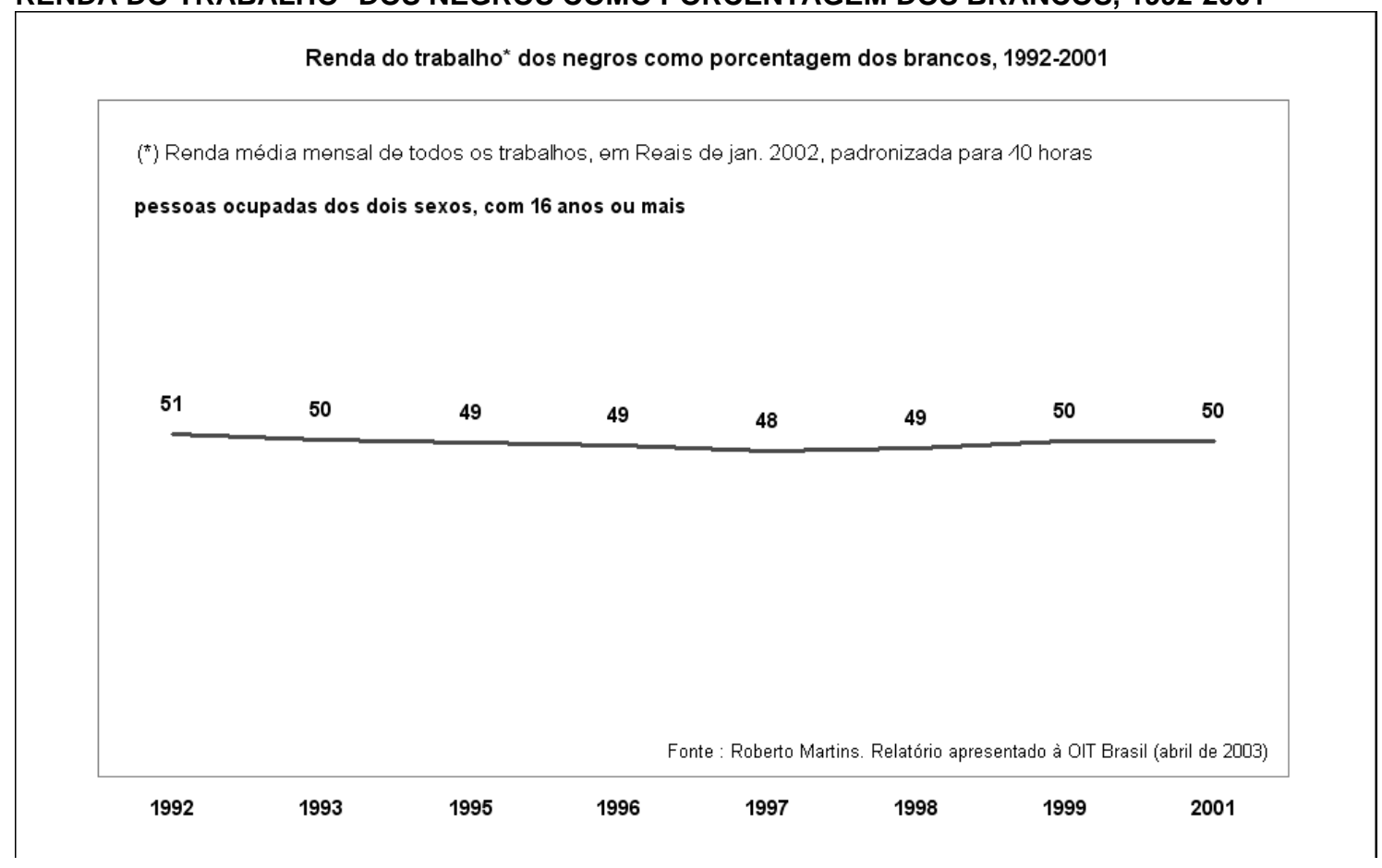

Fonte: Roberto Martins, Relatório apresentado à OIT Brasil (abril de 2003)

(*) Renda média mensal de todos os trabalhos, em Reais de jan. 2002, padronizada para 40 horas

Gráfico 15

RENDA DO TRABALHO* DOS NEGROS COMO PORCENTAGEM

DOS BRANCOS DO MESMO SEXO, 1992-2001 


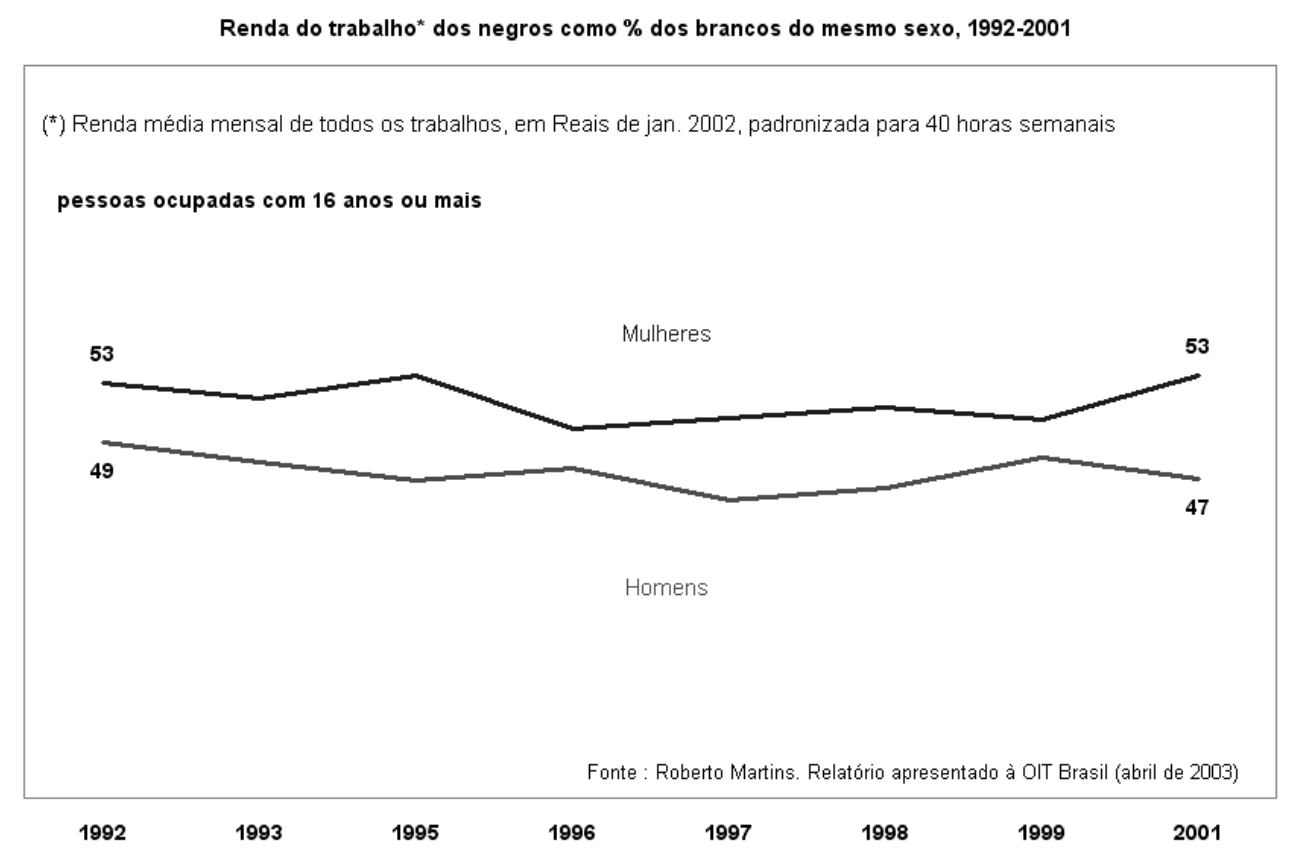

Fonte: Roberto Martins, Relatório apresentado à OIT Brasil (abril de 2003)

A desagregação por faixas etárias não altera esse padrão. O diferencial é menor na faixa mais jovem (16 a 24 anos), mas mesmo aqui os negros nunca alcançam $2 / 3$ da renda dos brancos, nem entre os homens nem entre as mulheres.

Tabela 6 RENDA* DE TODOS OS TRABALHOS, NEGROS COMO PORCENTAGEM DOS BRANCOS DA MESMA FAIXA ETÁRIA, 1992-2001

\begin{tabular}{|c|c|c|c|c|c|c|c|c|c|}
\hline 1992 & $\begin{array}{l}\text { Todos } \\
51\end{array}$ & $\begin{array}{l}16 \text { anos } \\
\text { ou mais } \\
\text { Homens } \\
49\end{array}$ & $\begin{array}{l}\text { Mulheres } \\
53\end{array}$ & $\begin{array}{l}25 \text { anos } \\
\text { ou mais } \\
\text { Todos } \\
50\end{array}$ & $\begin{array}{l}\text { Homens } \\
49\end{array}$ & $\begin{array}{l}\text { Mulheres } \\
52\end{array}$ & $\begin{array}{l}16 \text { a } 24 \\
\text { anos } \\
\text { Todos } \\
63\end{array}$ & $\begin{array}{l}\text { Homens } \\
64\end{array}$ & $\begin{array}{l}\text { Mulheres } \\
60\end{array}$ \\
\hline 1993 & 50 & 48 & 52 & 49 & 48 & 51 & 61 & 62 & 58 \\
\hline 1995 & 49 & 47 & 53 & 49 & 47 & 52 & 61 & 61 & 60 \\
\hline 1996 & 49 & 48 & 50 & 48 & 48 & 49 & 62 & 62 & 60 \\
\hline 1997 & 48 & 46 & 51 & 47 & 46 & 50 & 62 & 61 & 62 \\
\hline 1998 & 49 & 47 & 51 & 48 & 46 & 50 & 62 & 63 & 59 \\
\hline 1999 & 50 & 49 & 51 & 49 & 48 & 49 & 62 & 62 & 61 \\
\hline 2001 & 50 & 47 & 53 & 49 & 47 & 52 & 63 & 63 & 63 \\
\hline
\end{tabular}

Fonte : Roberto B. Martins. Desigualdades e Discriminação de Gênero e de Raça no Mercado Brasileiro de Trabalho no final do século XX. Relatório apresentado à OIT Brasil (abril de 2003)

Nota: $\left(^{*}\right)$ Renda média mensal, em reais de janeiro de 2002, padronizada para 40 horas semanais 
As tabelas e gráficos seguintes mostram a remuneração dos brancos e dos negros desagregadas por grandes grupos ocupacionais. Nelas se pode observar que em absolutamente todas as categorias ocupacionais (pelo menos no presente nível de desagregação), em todas as faixas de idade, e em todosos anos da série, a remuneração do trabalho dos negros é nitidamente inferior à dos brancos.

Os maiores hiatos raciais de renda ocorrem na categoria dos "conta própria". Isso acontece em virtude de ser muito pequena a porcentagem de profissionais e técnicos entre os negros autoempregados. Entre os homens negros ela não chega a $3 \%$ em nenhum dos anos estudados e entre as mulheres negras atinge, no máximo o nível de $5 \%$. Entre os "conta própria" brancos esta proporção é duas a três vezes mais alta, gerando a grande disparidade observada na média da ocupação.

A magnitude dos hiatos observados no serviço público é algo surpreendente. Entre todos os ocupados no setor, a remuneração média dos negros não atinge $2 / 3$ da remuneração dos brancos e mesmo entre os funcionários estatutários e militares essa porcentagem não chega a $70 \%$.

Dado o grau de codificação das normas de remuneração e de carreira vigentes na administração pública, é difícil acreditar que aí se encontre uma situação de discriminação salarial aberta, mas os dados indicam que ela está presente, provavelmente dissimulada em formas mais sutis, de segmentação ocupacional ou discriminação funcional. A extrema rarefação da presença de negros nos escalões médios e altos, nas carreiras de maior prestígio e de maior remuneração, nos cargos comissionados, nas chefias e nos níveis mais elevados das carreiras públicas, em todos os poderes e em todos os níveis de governo, é notória e visível a olho nu.

Entretanto, apesar de todas as evidências de sua existência, os caminhos e os mecanismos da exclusão racial no serviço público brasileiro são ainda pouco conhecidos e precisam de melhor estudo. Um passo importante nesta direção foi 
dado com a realização, no final do governo passado, do Censo Racial do Executivo Federal, ainda não divulgado pelo atual governo.

Nas faixas de 16 e de 25 anos ou mais, só no serviço doméstico encontramos um hiato inferior a 25 pontos percentuais. $\mathrm{Na}$ categoria seguinte, dos empregados agrícolas, as diferenças se mantêm entre 1/4 e 1/3 e, em todos os outros tipos de ocupação a remuneração dos brancos supera a dos negros por larga margem, que varia de 50 até $100 \%$. Na faixa de 16 a 24 anos as disparidades são menores, mas devemos lembrar que nesta faixa etária e neste nível de desagregação a redução pode ser fruto de problemas amostrais.

Tabela 7

RENDA* DO TRABALHO, OCUPADOS DE 16 ANOS OU MAIS, POR GÊNERO, RAÇA E TIPO DE OCUPAÇÃO, 1992 E 2001

\begin{tabular}{|c|c|c|c|c|c|c|c|c|}
\hline & Tipo de Ocupação & & $\begin{array}{l}\text { Todos } \\
\text { Brancos }\end{array}$ & $\begin{array}{l}\text { Todos } \\
\text { Negros }\end{array}$ & $\begin{array}{l}\text { Homens } \\
\text { Brancos }\end{array}$ & $\begin{array}{l}\text { Homens } \\
\text { Negros }\end{array}$ & $\begin{array}{l}\text { Mulheres } \\
\text { Brancas }\end{array}$ & $\begin{array}{l}\text { Mulheres } \\
\text { Negras }\end{array}$ \\
\hline \multirow[t]{7}{*}{1992} & $\begin{array}{l}\text { Funcionários públicos estatutários } \\
\text { militante }\end{array}$ & e & 937 & 594 & & 652 & 850 & 537 \\
\hline & Outros empregados no setor público & & 934 & 485 & 1047 & 591 & 709 & 370 \\
\hline & Empregados em empresas não agrícolas & & 601 & 350 & 1162 & 365 & 493 & 304 \\
\hline & Todos empregados em empresas agrícolas & & 203 & 138 & 653 & 142 & 168 & 111 \\
\hline & Todos os empregadores no setor privado & & 1513 & 876 & 208 & 871 & 1311 & 909 \\
\hline & Todos empregados em serviço doméstico & & 178 & 140 & 1555 & 163 & 175 & 139 \\
\hline & Todos ocupados por conta própria & & 528 & 1513 & 232 & 300 & 466 & 245 \\
\hline \multirow[t]{7}{*}{2001} & $\begin{array}{l}\text { Funcionários públicos estatutários } \\
\text { militante }\end{array}$ & e & 1265 & 862 & 1471 & 979 & 1111 & 750 \\
\hline & Outros empregados no setor público & & 906 & 546 & 1115 & 654 & 757 & 457 \\
\hline & Empregados em empresas não agrícolas & & 685 & 377 & 730 & 389 & 606 & 346 \\
\hline & Empregados em empresas agrícolas & & 235 & 170 & 238 & 173 & 213 & 145 \\
\hline & Todos os empregadores no setor privado & & 2027 & 1163 & 2130 & 1135 & 1711 & 1286 \\
\hline & Todos empregados em serviço doméstico & & 266 & 219 & 306 & 215 & 263 & 220 \\
\hline & Todos ocupados por conta própria & & 695 & 334 & 699 & 338 & 686 & 323 \\
\hline
\end{tabular}

Fonte : Roberto B. Martins. Desigualdades e Discriminação de Gênero e de Raça no Mercado Brasileiro de Trabalho no final do século XX. Relatório apresentado à OIT Brasil (abril de 2003)

Nota : $\left(^{*}\right)$ Renda média mensal da ocupação principal, em reais de janeiro de 2002, padronizada para 40 horas semanais

Dadas as grandes disparidades educacionais entre brancos e negros, e dado o fato de que a remuneração do trabalho é uma função crescente da escolaridade, é claro que o fator educação tem uma participação importante na geração das desigualdades de renda. Mas, com absoluta certeza, não se pode atribuir exclusivamente a esta causa +toda a amplitude das diferenças encontradas. É difícil acreditar, por exemplo, que possam ser imputadas à educação as disparidades de renda entre brancos e negros empregados no serviço doméstico ou na agricultura, ocupados como conta própria não 
profissionais ou técnicos, ou mesmo no conjunto dos assalariados informais. Essas categorias são notoriamente pouco exigentes em seus requisitos educacionais, e é pouco provável que os brancos nelas incluídos tenham níveis de escolaridade significativamente diferentes daqueles dos negros nas mesmas ocupações.

Tabela 8

RENDA* DO TRABALHO, NEGROS COMO PORCENTAGEM DOS BRANCOS, OCUPAÇÕES SELECIONADAS, 1992-2001

\begin{tabular}{|c|c|c|c|c|c|c|c|c|c|}
\hline $\begin{array}{l}\text { Demais } \\
\text { conta } \\
\text { própria(1) }\end{array}$ & $\begin{array}{l}\text { Serviço } \\
\text { Doméstico }\end{array}$ & & $\begin{array}{l}\text { Assa } \\
\text { infor }\end{array}$ & & & & & & \\
\hline $16+$ & $25+$ & $16-24$ & $16+$ & $25+$ & $16-24$ & $16+$ & $25+$ & $16-24$ & \\
\hline 1992 & 59 & 59 & 64 & 79 & 82 & 75 & 60 & 57 & 69 \\
\hline 1993 & 57 & 58 & 56 & 81 & 83 & 81 & 56 & 53 & 68 \\
\hline 1995 & 58 & 58 & 60 & 80 & 82 & 80 & 55 & 53 & 64 \\
\hline 1996 & 58 & 59 & 62 & 80 & 85 & 75 & 56 & 55 & 63 \\
\hline 1997 & 53 & 53 & 55 & 81 & 84 & 81 & 57 & 54 & 68 \\
\hline 1998 & 56 & 56 & 58 & 82 & 86 & 75 & 55 & 52 & 67 \\
\hline 1999 & 55 & 55 & 58 & 80 & 82 & 79 & 57 & 54 & 68 \\
\hline 2001 & 54 & 55 & 58 & 82 & 85 & 82 & 55 & 52 & 66 \\
\hline
\end{tabular}

Fonte : Roberto B. Martins. Desigualdades e Discriminação de Gênero e de Raça no Mercado Brasileiro de Trabalho o final do século XX. Relatório apresentado à OIT Brasil (abril de 2003)

Notas: $\left({ }^{*}\right)$ Renda média mensal da ocupação principal, em reais de janeiro de 2002, padronizada para 40 horas semanais (1) Todos os ocupados por conta própria exceto os profissionais e técnicos

(2) Todos os assalariados sem carteira assinada, inclusive os do setor público 
Renda média do trabalho*, por raça, ocupaçōes selecionadas, 2001

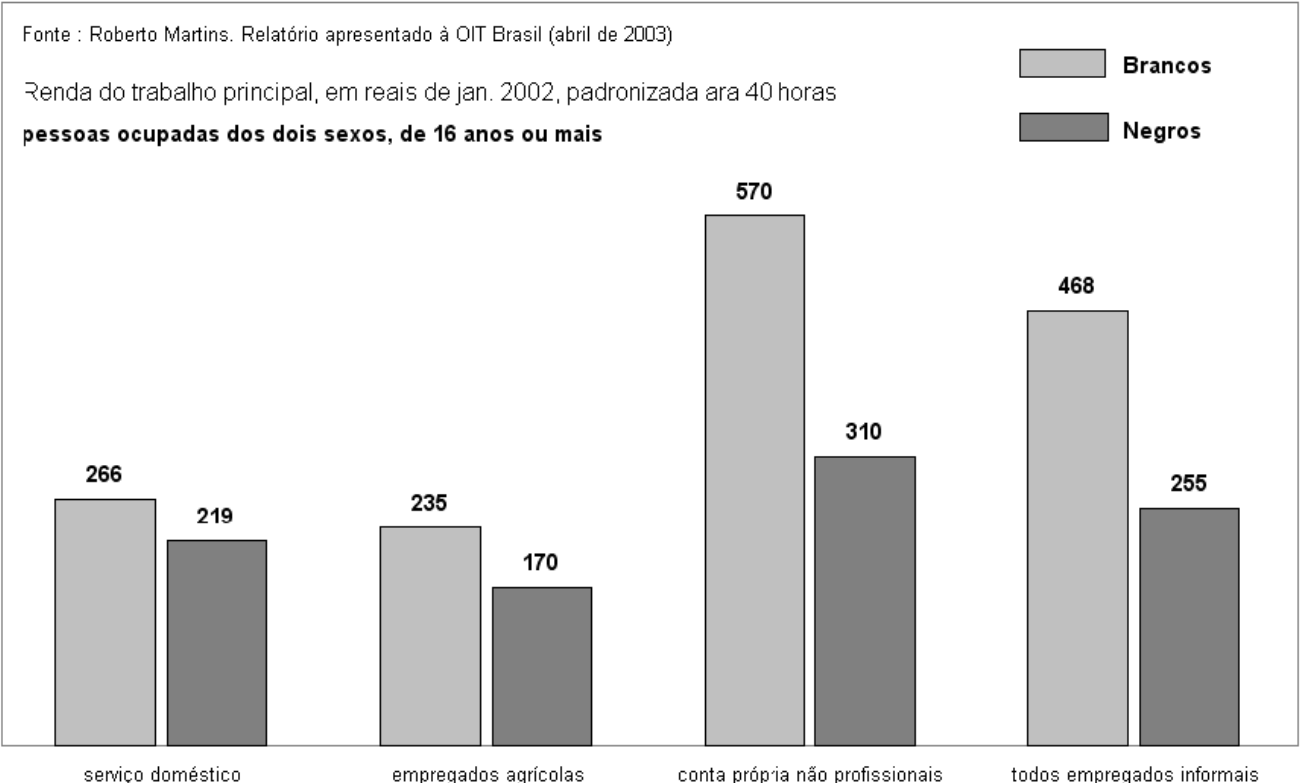

Fonte: Roberto Martins, Relatório apresentado à OIT Brasil (abril de 2003)

As tabelas e o gráfico seguintes acrescentam informações importantes para a conclusão de que as disparidades educacionais não explicam por si só as diferenças de rendimento observadas no mercado de trabalho. Aí se demonstra que em todos os níveis de escolaridade, nos dois sexos, e em todos os anos da série, a remuneração dos negros se situa entre 60 e $80 \%$ da renda dos brancos com o mesmo nível educacional. Esses dados sugerem fortemente a ocorrência de discriminação salarial, e são ainda mais reforçados pela observação, apresentada abaixo, de algumas situações de remuneração mais alta dos brancos mesmo quando comparados a negros com níveis mais altos de escolaridade. É importante notar também que as séries temporais não indicam nenhuma tendência de convergência dos níveis de remuneração.

Tabela 9

RENDA* DO TRABALHO, OCUPADOS DE 16 ANOS OU MAIS, POR GÊNERO, RAÇA E ESCOLARIDADE ,1992-2001

\begin{tabular}{|c|c|c|c|c|c|c|c|}
\hline \multirow[t]{4}{*}{1992} & $\begin{array}{l}\text { Escolaridade } \\
\text { (em anos) } \\
0 \text { a3 }\end{array}$ & $\begin{array}{l}\text { Todos } \\
\text { Brancos } \\
281\end{array}$ & $\begin{array}{l}\text { Todos } \\
\text { Negros } \\
199\end{array}$ & $\begin{array}{r}\text { Homens } \\
\text { brancos } \\
318\end{array}$ & $\begin{array}{l}\text { Homens } \\
\text { negros } \\
221\end{array}$ & $\begin{array}{l}\text { Mulheres } \\
\text { brancas } \\
218\end{array}$ & $\begin{array}{l}\text { Mulheres } \\
\text { Negras } \\
159\end{array}$ \\
\hline & 4 a7 & 400 & 291 & 470 & 336 & 283 & 213 \\
\hline & 8 a 10 & 556 & 391 & 638 & 452 & 423 & 290 \\
\hline & 11 a 14 & 878 & 624 & 1051 & 758 & 675 & 490 \\
\hline
\end{tabular}




\begin{tabular}{|c|c|c|c|c|c|c|c|}
\hline & 15 ou mais & 1911 & 1408 & 2397 & 1744 & 1362 & 1097 \\
\hline & Todas & 605 & 307 & 691 & 342 & 475 & 250 \\
\hline \multirow[t]{6}{*}{2001} & 0 a3 & 316 & 223 & 341 & 232 & 274 & 206 \\
\hline & 4 a7 & 424 & 313 & 481 & 341 & 332 & 264 \\
\hline & 8 a 10 & 533 & 390 & 608 & 446 & 420 & 307 \\
\hline & 11 a 14 & 866 & 589 & 1047 & 704 & 673 & 474 \\
\hline & 15 ou mais & 2343 & 1714 & 2937 & 2138 & 1769 & 1348 \\
\hline & Todas & 757 & 376 & 847 & 402 & 634 & 336 \\
\hline
\end{tabular}

\footnotetext{
Fonte : Roberto B. Martins. Desigualdades e Discriminação de Gênero e de Raça no Mercado Brasileiro de Trabalho no final do século XX. Relatório apresentado à OIT Brasil (abril de 2003)

Nota: $\left(^{*}\right)$ Renda média mensal de todos os trabalhos, em reais de janeiro de 2002, padronizada para 40 horas semanais.

\section{Tabela 10 \\ RENDA* DO TRABALHO : NEGROS COMO PORCENTAGEM DOS BRANCOS DO MESMO SEXO, POR ESCOLARIDADE, 1992-2001}

\begin{tabular}{lllllllll}
\hline $\begin{array}{l}\text { Gênero e faixa de escolaridade } \\
\text { Todos Negros }\end{array}$ & $\mathbf{1 9 9 2}$ & $\mathbf{1 9 9 3}$ & $\mathbf{1 9 9 5}$ & $\mathbf{1 9 9 6}$ & $\mathbf{1 9 9 7}$ & $\mathbf{1 9 9 8}$ & $\mathbf{1 9 9 9}$ & $\mathbf{2 0 0 0}$ \\
0 a3 & 71 & 71 & 66 & 69 & 68 & 70 & 69 & 71 \\
4 a 7 & 73 & 70 & 74 & 70 & 71 & 72 & 72 & 74 \\
8 a 10 & 70 & 72 & 78 & 72 & 69 & 74 & 74 & 73 \\
11 a 14 & 71 & 70 & 69 & 68 & 66 & 68 & 69 & 68 \\
15 anos ou mais & 74 & 77 & 72 & 72 & 74 & 74 & 77 & 73 \\
Homens Negros & & & & & & & & \\
0 a3 & 70 & 69 & 62 & 66 & 67 & 68 & 68 & 68 \\
4 a 7 & 71 & 70 & 73 & 69 & 71 & 72 & 71 & 71 \\
8 a 10 & 71 & 71 & 78 & 74 & 67 & 72 & 73 & 73 \\
11 a 14 & 72 & 71 & 70 & 70 & 67 & 6 & 72 & 67 \\
15 anos ou mais & 73 & 76 & 71 & 74 & 73 & 76 & 84 & 73 \\
Mulheres Negras & & & & & & & & \\
0 a3 & 73 & 72 & 72 & 74 & 72 & 72 & 70 & 75 \\
4 a 7 & 75 & 73 & 74 & 72 & 73 & 75 & 74 & 79 \\
8 a 10 & 69 & 76 & 79 & 71 & 76 & 80 & 76 & 73 \\
11 a 14 & 73 & 70 & 70 & 69 & 68 & 69 & 68 & 70 \\
15 anos ou mais & 81 & 84 & 78 & 70 & 79 & 74 & 73 & 76
\end{tabular}

Fonte : Roberto B. Martins. Desigualdades e Discriminação de Gênero e de Raça no Mercado Brasileiro de Trabalho no final do século XX. Relatório apresentado à OIT Brasil (abril de 2003).

Notas: (1) Renda média mensal de todos os trabalhos, em reais de janeiro de 2002, padronizada para 40 horas semanais (2) Inclui todos os ocupados com remuneração, de 16 anos ou mais

Tabela 11

RENDA* DO TRABALHO, POR GÊNERO E RAÇA, COM ESCOLARIDADE DEFASADA, 1992-2001

\begin{tabular}{lllllllllllll}
\hline & Homens & Homens & $\%$ & Homens & Homens & $\%$ & Mulheres & Mulheres & \% & Mulheres & Mulheres & $\%$ \\
& Brancos & Negros & & Brancos & Negros & & Brancas & Negras & & Brancas & Negras & \\
& 03 & 4 a 7 & & 4 a7 & 8 a 10 & & 0 a 3 & 4 a 7 & & 4 a 7 & 8 a 10 & \\
1992 & 318 & 336 & 106 & 470 & 452 & 96 & 218 & 213 & 98 & 283 & 290 & 102 \\
1993 & 318 & 334 & 105 & 478 & 456 & 96 & 214 & 205 & 96 & 283 & 294 & 104 \\
1995 & 404 & 411 & 102 & 561 & 588 & 105 & 279 & 273 & 98 & 370 & 360 & 97 \\
\hline
\end{tabular}




\begin{tabular}{lllllllllllll}
\hline 1996 & 398 & 405 & $\mathbf{1 0 2}$ & 584 & 568 & $\mathbf{9 7}$ & 300 & 280 & $\mathbf{9 3}$ & 391 & 352 & $\mathbf{9 0}$ \\
1997 & 389 & 394 & $\mathbf{1 0 1}$ & 558 & 513 & $\mathbf{9 2}$ & 295 & 263 & $\mathbf{8 9}$ & 359 & 352 & $\mathbf{9 8}$ \\
1998 & 370 & 382 & $\mathbf{1 0 3}$ & 531 & 507 & $\mathbf{9 5}$ & 300 & 267 & $\mathbf{8 9}$ & 357 & 358 & $\mathbf{1 0 0}$ \\
1999 & 341 & 354 & $\mathbf{1 0 4}$ & 500 & 466 & $\mathbf{9 3}$ & 289 & 255 & $\mathbf{8 8}$ & 343 & 313 & $\mathbf{9 1}$ \\
2001 & 341 & 341 & $\mathbf{1 0 0}$ & 481 & 446 & $\mathbf{9 3}$ & 274 & 264 & $\mathbf{9 6}$ & 332 & 307 & $\mathbf{9 2}$ \\
\hline
\end{tabular}

Fonte : Roberto B. Martins. Desigualdades e Discriminação de Gênero e de Raça no Mercado Brasileiro de Trabalho no final do século XX. Relatório apresentado à OIT Brasil (abril de 2003)

Notas: (1) Renda média mensal de todos os trabalhos,em reais de janeiro de 2002, padronizada para 40 horas semanais

(2) Inclui todos os ocupados com remuneração, de 16 anos ou mais

Simulações contrafactuais simples podem nos ajudar a avançar um pouco mais nessa questão. O exercício consiste em atribuir aos negros o mesmo perfil educacional dos brancos, mantendo os diferenciais observados de remuneração em cada faixa de escolaridade. Com isso é possível decompor a diferença total das médias em duas parcelas, uma imputável às diferenças educacionais e outra que não é explicada pela educação, devendo ser atribuída a "outras causas".

Os resultados são apresentados na tabela e no gráfico na página seguinte.

Gráfico 17

SIMULAÇÃO CONTRAFACTUAL: TODOS NEGROS X TODOS BRANCOS

Simulação contrafactual : Todos negros $\mathrm{x}$ Todos brancos

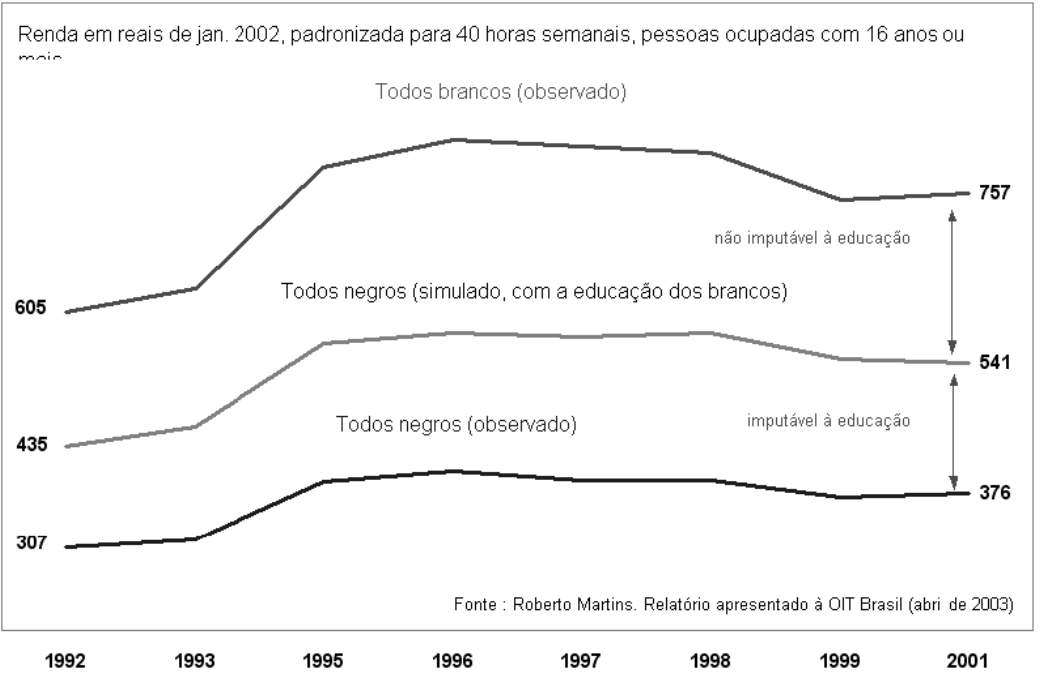

Fonte: Roberto Martins, Relatório apresentado à OIT Brasil (abril de 2003)

Tabela 12

PERCENTUAIS DOS HIATOS DE RENDA DO TRABALHO NÃO CAUSADOS PELAS DIFERENÇAS EDUCACIONAIS*

\begin{tabular}{llll}
\hline Todos negros & $\begin{array}{c}\text { Todos negros } \\
\mathbf{X}\end{array}$ & $\begin{array}{c}\text { Homens negros } \\
\mathbf{X}\end{array}$ & $\begin{array}{c}\text { Mulheres negras } \\
\mathbf{X}\end{array}$ \\
& Todos brancos & Homens brancos & Mulheres brancas \\
1992 & 57 & 56 & 53 \\
\hline
\end{tabular}




\begin{tabular}{llll}
\hline 1993 & 55 & 54 & 51 \\
1995 & 56 & 55 & 54 \\
1996 & 58 & 55 & 59 \\
1997 & 57 & 57 & 54 \\
1998 & 55 & 52 & 55 \\
1999 & 54 & 48 & 58 \\
2001 & 57 & 56 & 55
\end{tabular}

Fonte : Roberto B. Martins. Desigualdades e Discriminação de Gênero e de Raça no Mercado Brasileiro de Trabalho no final do século XX. Relatório apresentado à OIT Brasil (abril de 2003)

Nota: (*) Simulação : Renda média dos negros, com o perfil educacional dos brancos do mesmo sexo e sua própria remuneração em cada faixa de escolaridade

As simulações demonstram que as disparidades educacionais (que são geradas fora do mercado de trabalho), embora grandes e persistentes, são responsáveis por menos da metade dos hiatos observados na remuneração média. A maior parcela dessas diferenças é gerada no mercado de trabalho, e é causada por outros fatores, entre os quais se incluem certamente a segmentação ocupacional e um forte componente de discriminação salarial baseada na raça.(no original tem uma citação de n. 09 pag.40).

De uma perspectiva mais ampla, entretanto, pode-se afirmar que as diferenças de renda são, sem nenhuma dúvida, integralmente causadas por discriminação e exclusão racial. Ao tentar sua decomposição analítica, em parcelas imputáveis à educação e parcelas imputáveis a outros fatores, o que estamos fazendo, na verdade é, pura e simplesmente, tentando separar os efeitos da discriminação ou exclusão presente dos efeitos da discriminação ou exclusão pretérita.

Pois a disparidade hoje observada na educação não é outra coisa senão a manifestação presente de exclusões ancestrais, de discriminações passadas transmitidas de geração a geração, em cadeias de causalidade que remontam à época do tráfico e da escravidão, e que incluem não apenas a negação do acesso à educação, mas também à renda, à propriedade, à acumulação de riqueza, ao poder político e à própria cidadania. Não obstante, a decomposição é importante. Não se trata de hierarquizar, em uma escala ética, mazelas do presente e mazelas do passado, e sim de identificar dimensões distintas de um mesmo problema, que 
se interpenetram e se combinam para gerar as iniqüidades de hoje, mas que certamente demandam abordagens e políticas distintas para seu enfrentamento.

O mercado nacional de trabalho não é homogêneo. As conhecidas disparidades regionais de desenvolvimento econômico e social obviamente se manifestam também nos mercados regionais de trabalho, sob a forma de níveis diferenciados de produtividade e de remuneração dos trabalhadores. Tampouco é homogênea a distribuição regional, por raça, da PEA e da população ocupada. Apopulação negra é relativamente mais concentrada no Nordeste e no Norte, que são as regiões com menores níveis de renda e de remuneração do trabalho. Assim, torna-se necessário verificar se as disparidades encontradas nas médias nacionais de remuneração são devidas à heterogeneidade da distribuição espacial das raças, ou se elas permanecem quando esse fator é considerado.

Tabela 13

RENDA* DO TRABALHO: NEGROS COMO PORCENTAGEM DOS BRANCOS, POR REGIÕES, $1992-2001$

\begin{tabular}{llllll}
\hline Anos & Norte & Nordeste & Sudeste & Sul & C. Oeste \\
1992 & 59 & 53 & 52 & 58 & 54 \\
1993 & 58 & 49 & 52 & 55 & 57 \\
1995 & 64 & 53 & 52 & 60 & 56 \\
1996 & 57 & 52 & 51 & 55 & 56 \\
1997 & 57 & 50 & 49 & 57 & 54 \\
1998 & 60 & 48 & 50 & 61 & 53 \\
1999 & 60 & 51 & 51 & 54 & 53 \\
2001 & 58 & 52 & 50 & 61 & 52 \\
\hline
\end{tabular}

Fonte: Luciana Jaccoud e Nathalie Beghin. Desigualdades Raciais no Brasil. Brasília: IPEA, 2002.

Nota: $\left({ }^{*}\right)$ Renda média da ocupação principal, de todos os ocupados, em reais de janeiro de 2002. 
Renda do trabalho dos negros como porcentagem dos brancos, por regiões, 2001

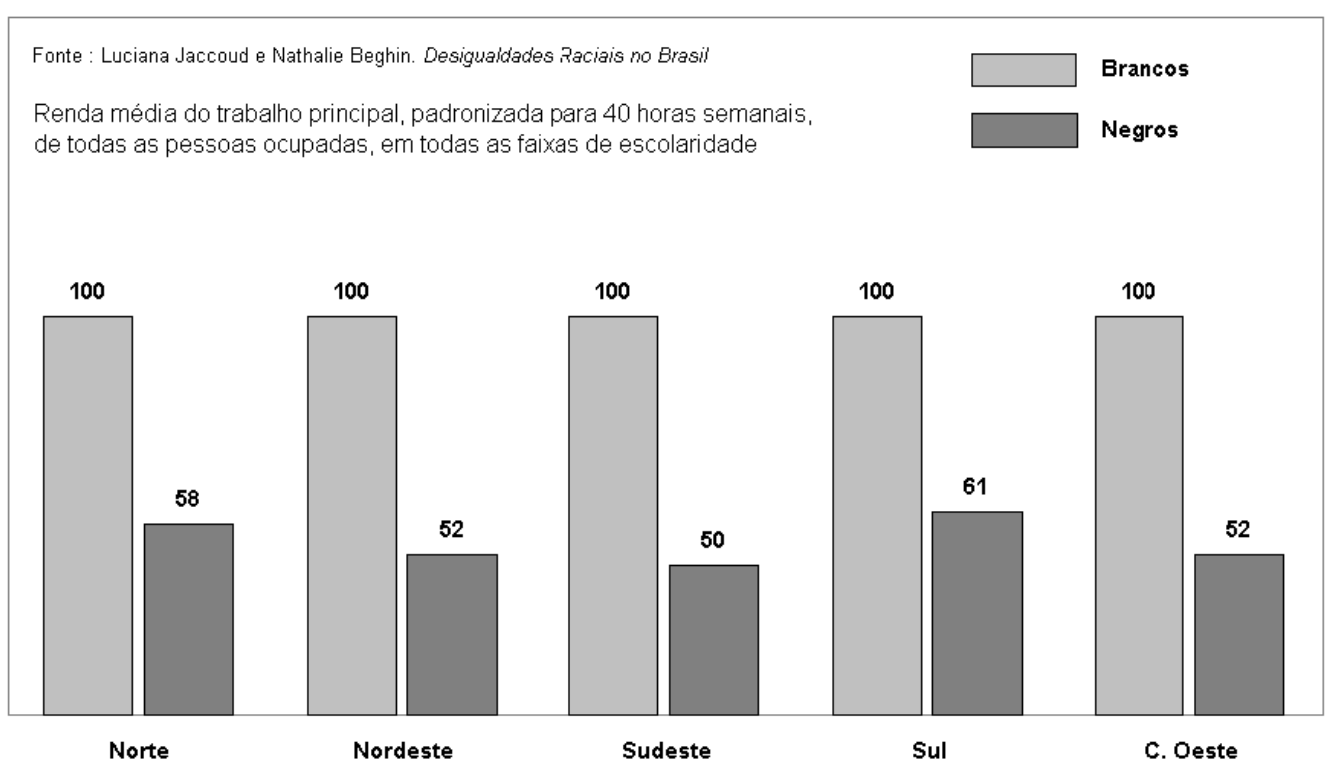

Fonte: Luciana Jaccoud e Nathalie Beghin. DesigualdadesRaciais no Brasil.

Os números acima são bastante claros. O hiato entre negros e brancos não só está presente em todas as regiões, independentemente do seu nível de desenvolvimento ou das condições específicas do seu mercado de trabalho, como também apresenta variações regionais relativamente pequenas em torno da média nacional. Isso nos permite concluir que a heterogeneidade da distribuição racial da população no território brasileiro não pode ser responsabilizada pelas disparidades de renda observadas entre as raças.

\section{4. -. Emprego Informal}

A informalidade é uma das formas de inserção precária no mercado de trabalho. A definição de informalidade aqui adotada se refere apenas aos empregados assalariados, e a taxa de informalidade é definida como a porcentagem de empregados "sem carteira assinada" (inclusive os do setor público) no total dos empregados públicos ou privados, aí incluídos os funcionários públicos estatutários e militares. Da ótica jurídica esta é uma situação ilegal e, do ponto de vista social, constitui uma modalidade de inserção precária, por negar ao trabalhador a proteção da legislação trabalhista e previdenciária e submetê-lo a 
níveis de insegurança e de instabilidade muito maiores do que aqueles enfrentados pelos empregados formais, ou "com carteira assinada".

Tabela 14

TAXA DE INFORMALIDADE DOS ASSALARIADOS*, POR RAÇA E FAIXA ETÁRIA, 1992-2001

\begin{tabular}{lllclll}
\hline & 16anos ou mais & & \multicolumn{2}{c}{ Todos25 anos ou } & \multicolumn{2}{c}{ tT16 a 24 anos } \\
Brancos & Negros & Todos Brancos & Negros & Brancos & Negros \\
1992 & 28 & 44 & 24 & 38 & 39 & 59 \\
1993 & 29 & 46 & 25 & 39 & 41 & 60 \\
1995 & 29 & 45 & 25 & 39 & 39 & 59 \\
1996 & 30 & 45 & 26 & 39 & 42 & 58 \\
1997 & 30 & 45 & 27 & 40 & 40 & 58 \\
1998 & 31 & 45 & 27 & 40 & 41 & 60 \\
1999 & 31 & 46 & 28 & 41 & 41 & 59 \\
2001 & 31 & 46 & 28 & 41 & 41 & 59
\end{tabular}

Fonte : Roberto B. Martins. Desigualdades e Discriminação de Gênero e de Raça no Mercado Brasileiro de Trabalho no final do século XX. Relatório apresentado à OIT Brasil (abril de 2003)

Nota: $\left({ }^{*}\right)$ Inclui todos os assalariados ou empregados "sem carteira assinada", inclusive os do setor público

Gráfico 19

TAXA DE INFORMALIDADE NO EMPREGO, POR GÊNERO E RAÇA, 1992-2001

Taxa de informalidade no emprego, por gênero e raça, 1992-2001

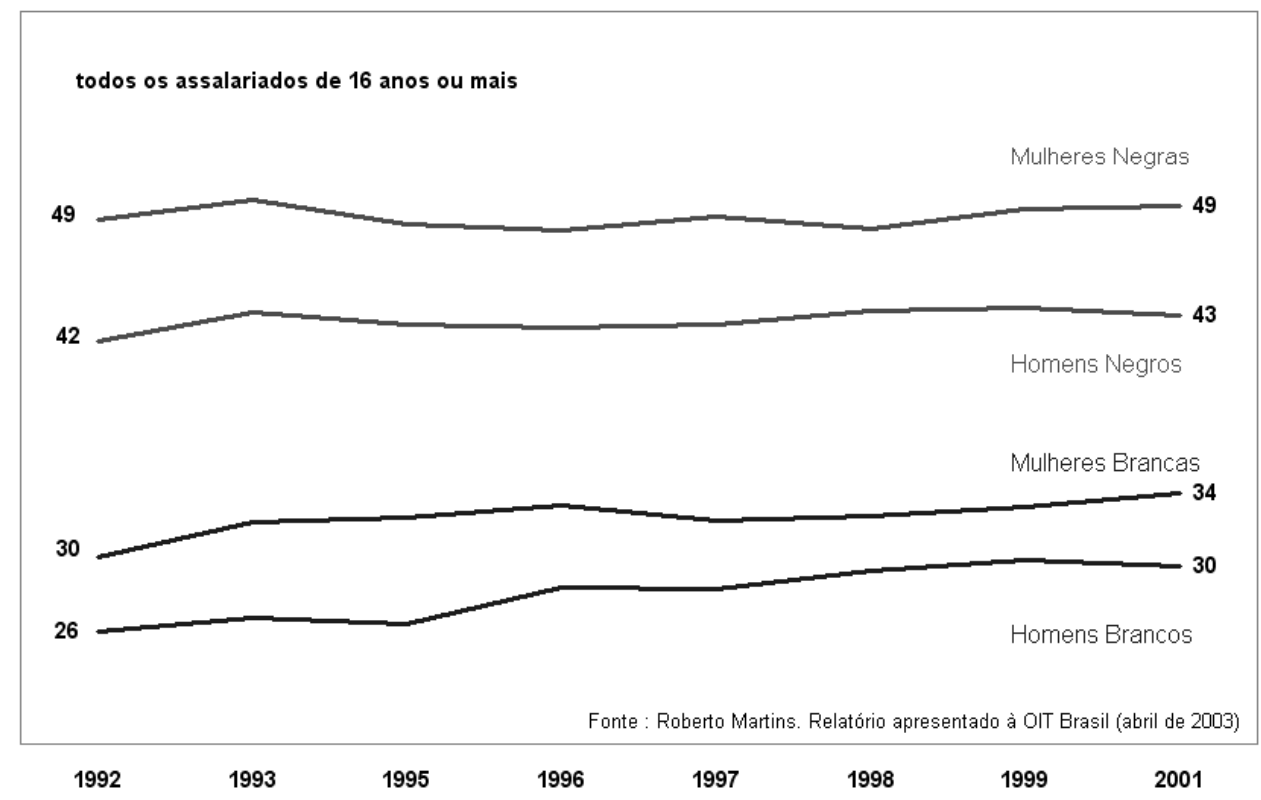

Fonte: Roberto Martins, Relatório apresentado à OIT Brasil (abril de 2003) 
Como se pode observar na tabela, a taxa de informalidade no mercado brasileiro de trabalho apresentou níveis elevados no período em estudo, sobretudo na faixa etária mais jovem (16 a 24 anos), mas permaneceu relativamente estável, com uma tendência ascendente muito moderada. A taxa de informalidade das mulheres é sempre mais alta que a dos homens, mas as diferenças não chegam a ultrapassar o nível de um dígito (em pontos percentuais), mesmo na faixa etária mais jovem, onde os níveis absolutos são bem mais elevados.

As desigualdades entre as raças são muito mais pronunciadas. O grau de informalidade dos trabalhadores negros é significativamente mais alto que o dos trabalhadores brancos, tanto para o conjunto de cada raça, como no caso de cada sexo tomado separadamente. Em nenhum ano da série o hiato de informalidade entre as raças se situa abaixo de dois dígitos, mesmo entre os adultos de 25 anos ou mais. Entre os jovens de 16 a 24 anos essas disparidades se mantém sempre em torno de 20 pontos percentuais.

O gráfico mostra um rígido padrão de hierarquização das taxas de informalidade, com dominância principal do critério raça, seguido do critério gênero, invariável ao longo de toda a série. Ou seja, em todos os anos, as taxas têm a mesma ordenação: negros acima de brancos, independentemente do sexo, e dentro de cada raça, as mulheres acima dos homens.

O conceito de precarização da ocupação adotado pela OIT é bem mais abrangente que o conceito de informalidade acima mencionado, e tem como referência toda a população ocupada, e não apenas os empregados assalariados. Traduzido em termos das categorias ocupacionais da PNAD, esse conceito inclui como ocupações precárias: o emprego assalariado sem carteira assinada (os trabalhadores informais), a ocupação por conta própria não profissional ou técnica, todas as ocupações sem remuneração (que na classificação usada neste estudo são representadas pela soma das ocupações para uso ou para consumo próprio, com as "demais ocupações sem remuneração"), e ainda os empregados em empresas com cinco empregados ou menos, mesmo que tenham carteira de trabalho assinada. 
A tabela e o gráfico abaixo apresentam um sumário da precarização do trabalho no Brasil na década de 90 , mostrando que a proporção de trabalhadores com inserção precária foi extremamente elevada. Em nenhum ano da série, em nenhuma faixa etária, e em nenhuma combinação de gênero e raça, a taxa de precarização apresenta um valor inferior a $50 \%$ da população ocupada.

Tabela 15

TAXA DE PRECARIZAÇÃO DA OCUPAÇÃO* (CONCEITO OIT), POR RAÇA DE FAIXA ETÁRIA RAÇA, 1992-2001

\begin{tabular}{lllclll}
\hline & 16anos ou mais & Negros & Todos25 anos ou & Tt16 a 24 anos & \\
& Brancos & Todos Brancos & Negros & Brancos & Negros \\
1992 & 52 & 66 & 50 & 63 & 58 & 73 \\
1993 & 53 & 66 & 51 & 63 & 59 & 74 \\
1995 & 53 & 66 & 51 & 64 & 58 & 73 \\
1996 & 54 & 66 & 49 & 61 & 60 & 73 \\
1997 & 53 & 66 & 52 & 64 & 58 & 73 \\
1998 & 53 & 67 & 51 & 64 & 59 & 74 \\
1999 & 54 & 67 & 52 & 65 & 59 & 75 \\
2001 & 52 & 65 & 51 & 63 & 57 & 72
\end{tabular}

Fonte : Roberto B. Martins. Desigualdades e Discriminação de Gênero e de Raça no Mercado Brasileiro de Trabalho no final do século XX. Relatório apresentado à OIT Brasil (abril de 2003)

Nota: $\left(^{*}\right)$ Porcentagem de trabalhadores em ocupações precárias sobre o total de ocupados. Veja o texto para o conceito de "ocupações precárias" adotado pela OIT.

Grafico 20

TAXA DE PRECAROZAÇÃO (CONCEITO OIT), ${ }^{*}$ POR GÊNERO E RAÇA, 1992-2001

Taxa de informalidade no emprego, por gênero e raça, 1992-2001

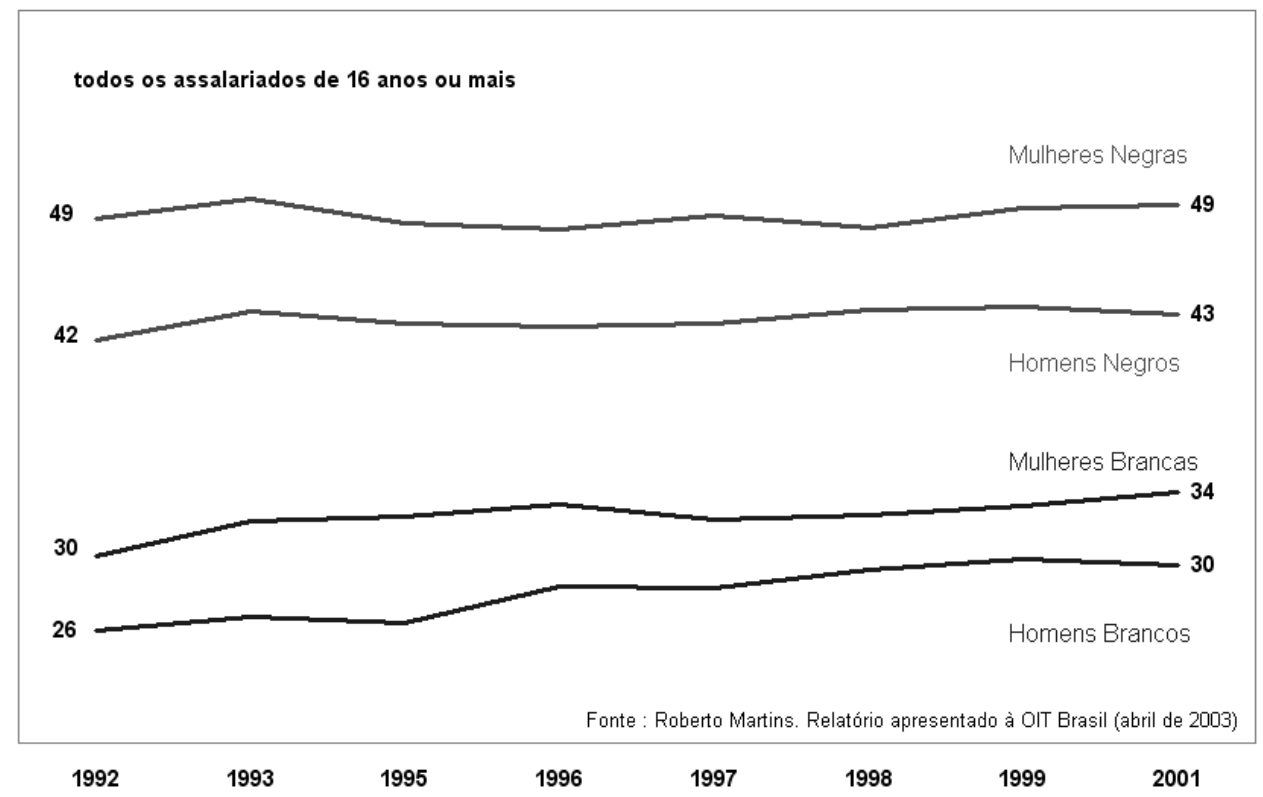

Fonte: Roberto Martins, Relatório apresentado à OIT Brasil (abril de 2003) 
Examinando o problema pela ótica de gênero e de raça, podemos ver que o rígido padrão de ordenação (com dominância do fator raça e secundariamente do fator gênero) observado nas taxas de informalidade é integralmente repetido aqui: as taxas dos negros são mais altas que as dos brancos, independentemente do gênero, e no interior de cada grupo racial, as mulheres sempre suplantam os homens em termos desse indicador. A ligeira tendência ao declínio nas taxas femininas (tanto entre as brancas quanto entre as negras, se deve a uma notável redução no componente "ocupados sem remuneração"). O nível de precarização dos trabalhadores negros é sensivelmente mais alto que o dos brancos, em todos os anos, nos dois sexos e em todas as faixas etárias, situando-se sempre em torno de $2 / 3$ ou mais da população ocupada. Na faixa de 16 a 24 anos a taxa dos negros é sempre superior a $70 \%$, e chega a atingir $76 \%$ no caso das mulheres negras. 


\section{QUARTO CAPÍTULO}

\section{Movimentos social negro idéias reivindicadoras da civilidade}

\section{1 - Movimentos Socias Negros e Estado}

Neste capítulo adotaremos a concepção de Gohn (2004, p. 247) para movimento social, como aquilo que diz respeito a ação dos homens na história. Esta ação envolve "um fazer - por meio de um conjunto de procedimentos - e um

pensar - por meio de um conjunto de idéias (grifo nosso) que motiva ou dá fundamentação à ação". 
Dentro desta perspectiva histórica focalizaremos as organizações negras, mais especificamente as três de maior projeção pós Abolição; Imprensa Negra, (1915) Frente Negra Brasileira (1931) e Movimento Negro Unificado, (1978) que de diferentes maneiras se destacaram na luta social de denúncia e de combate ao racismo.

Para essas organizações negras o combate ao racismo se colocava ao centro da luta social se constituindo em reivindicação concreta e estruturante da luta social empreendida pelo que comumente é chamado de movimento negro.

Através da luta contra o racismo, empreendida por essas organizações pode-se captar as estratégias de combate ao racismo e a dinâmica das idéias racistas e anti-racistas Dessa forma buscamos geografizar a ação social das organizações negras pela apreensão dos processos sócio-espaciais que originaram seu surgimento. E que nos leva crer que a ação social das organizações negras ocorre como reação à discriminação racial presente em todas as esferas da sociedade em diferentes períodos e lugares.

Para Smith, os movimentos sociais são tanto produto como agentes de transformações socioespaciais. As organizações negras do passado e mesmo as atuais não fogem a essa regra, surgiram como produto das discriminações raciais e ao longo dos quase cem últimos anos se constituíram em agentes transformadores da política racial do Estado.

Nas abordagens geográficas o Estado é entendido como a forma política do território, este se definindo em função do uso ou dos diferentes usos que lhe são 
empregados. Outra possibilidade que nos parece viável seria defini-lo a partir das reivindicações feitas pelos grupos de interesses que dele fazem objeto de disputa para uso, pois para além da dimensão material do Estado, o território é também um composto de espacialidades que são sua expressão política, econômica, social, cultural e técnica.

Disso decorre um outro ponto deste capítulo distinguir a natureza e o propósito das ações de caráter antidiscriminatório das de combate as desigualdades raciais, demonstrando que a finalidade do fazer e do pensar a ação histórica, no caso das organizações negras, busca o conviver integrado e o ser diferente sem por isso perder ou ter que provar dignidade dentro da igualdade de ser brasileiro.

\section{2 - Organizações negras: Imprensa Negra, Frente Negra Brasileira e Movimento Negro Unificado}

Uma das mais importantes manifestações sociais de natureza racial do século 20 foi o que ficou conhecido por Imprensa Negra cujo o primeiro jornal circula em 1915, na cidade de São Paulo, sob o título de Menelick. A chamada Imprensa Negra se torna entre 1915 a 1963, ano de fechamento do jornal Correio d'Ebano o principal porta voz da comunidade negra paulista s denúncias, críticas e reivindicações de ativistas e intelectuais negros a ordem racial brasileira.

A invisibilidade do negro levou membros da classe média negra paulistana a fundar uma imprensa alternativa, na qual pudessem manifestar sua indignação, 
suas aspirações e denúncias contra o racismo, bem como divulgar sua vida, cultural e social.

Para Sodré (1998) a imprensa negra era política sem ser partidária, difundindo através dos artigos os anseios ascencionais ou integracionistas de um grupo social definido pela cor e pela origem escrava. Pode-se a firmar que foi o primeiro discurso valorativo dos negros e, anti-racista, visto que os movimentos abolicionistas do século XIX se pautaram no discurso da liberdade, mais do que o da igualdade.

"Mais: nós, os Negros (mestiços do Brasil) demos as mais acabadas mentalidades nacionais e os mais sublimes artistas, nomeadamente na música e na literatura em geral. [...] Relegamnos, pois, a nós Brasileiros, a uma posição horrível de inferioridade e desprestígio perante o nacional branco, e, o que mais revolta, perante o estrangeiro". [...] O problema negro brasileiro é o da integralização absoluta, completa, do Negro em toda a vida brasileira (política, social, religiosa, econômica, operária, militar, etc.); deve ter toda a aceitação, em tudo e em toda a parte, dadas as condições competentes, físicas, técnicas, intelectuais e morais, exigidas para a igualdade perante a lei." "MENSAGEM AOS NEGROS BRASILEIROS”, O CLARIM D'ALVORADA, SÃO PAULO, 9 DE JUNHO DE 1929

Ao direcionar suas notícias para a comunidade negra ${ }^{18}$, a imprensa negra foi forjando uma ideologia anti-racista que impulsionou o surgimento de formas políticas de organização social, como a Frente Negra Brasileira, fundada em 1931

\footnotetext{
${ }^{18}$ Clovis Moura que pesquisou os jornais se surpreendeu com o fato dos jornais não noticiarem os grandes acontecimentos nacionais da época como a Coluna Prestes, a Revolução de 1930, o Movimento de 1932 etc. Assim como noticias sobre o movimento sindical, lutas operárias, greves e a participação de negros nessas manifestações. E também da ausência de críticas ao governo, concluindo que havia uma certa cautela nos temas abordados e um direcionamento de público bastante específico.
} 
e extinta em 1937 pela ditadura Vargas, um ano depois de ser transformada pelos frentenegrinos em partido político. Sobre a Frente Negra Brasileira vale a pena ver Moura (1992) Pahim (1993) e o livro de Márcio Barbosa (1998) que reúne depoimentos colhidos em vida, de alguns dos antigos integrantes da FNB.

No trabalho de Barbosa, os depoimentos dos entrevistados registram a diversificada atuação da FNB, com destaque nas áreas política, cultural e social. Destacamos um trecho do depoimento de Francisco Lucrécio.

A Frente Negra foi um movimento social que ajudou muito nas lutas pelas posições do negro aqui em São Paulo. Existiam diversas entidades negras. [...] mas a Frente veio com um programa de luta para conquistar posições para o negro em todos os setores da vida brasileira. Um dos seus departamentos, inclusive, enveredou pela questão política, porque nós chegamos à conclusão de que, para conquistar o que desejávamos, teríamos de lutar no campo político, teríamos de ter um partido que verdadeiramente nos representasse. [...] havia o departamento esportivo, o musical, o feminino, o educacional, o de instrução moral e cívica. [...] muitas entidades de negros que cuidavam de recreação filiaram-se à Frente Negra. Existiam diversas sociedades em São Paulo e pelo interior afora. Por isso a Frente cresceu muito, cresceu de tal maneira que tinha delegação no Rio de Janeiro, na Bahia, no Rio Grande do Sul, Minas Gerais. [...] As entidades do interior de São Paulo se filiavam. Tinham conhecimento através do nosso jornal: A Voz da Raça. Aí vinha uma comissão do interior saber como poderia entrar na Frente. [...] Quase toda cidade do interior tinha Frente Negra: Sorocaba, Tietê, Campinas, Ribeirão Preto, [...] Mas as delegações maiores que nós tínhamos eram em Minas Gerais, Rio de Janeiro e São Paulo. [...] Se fôssemos fazer os cálculos, superaria vinte mil filiados. (Barbosa, idem, p.38-9) 
No depoimento de Lucrécio fica nítido a influência que durante os anos 30 a Frente Negra exerceu sobre a comunidade negra brasileira e como ela se espacializou pelo território, inaugurando um discurso contestador da igualdade vigente e reivindicador da integração assimilada do negro na sociedade.

De 1930 a 1970, o luta anti-racista ganha novos contornos, embora a FBN tenha inaugurado a luta anti-racista e a denúncia de relações raciais desiguais, seu discurso não foi de ruptura com a sociedade, fato que só aconteceu 47 anos depois. Em 1978 surge o Movimento Unificado Contra a Discriminação Racial. O MNU - Movimento Negro Unificado, nome com que se popularizou surgiu primeiramente em São Paulo, aos 18 de julho de 1978, realizando sua primeira atividade pública em 7 de julho do mesmo ano. A manifestação foi um ato público contra o racismo, em frente as escadarias do Teatro Municipal de São Paulo.

Inicia-se a partir de então a fase de luta anti-racista, diferencialista ${ }^{19}$. Influenciados pela luta dos direitos nos Estados Unidos e pelos movimentos de independência africanos, o MNU formula um discurso de amor e respeito a diferença, evocando uma identidade negra, em substituição a identidade mestiça.

A luta pela emancipação racial se faz pela atividade consciente, organizada em torno de entidades sociais, pela denúncia do racismo e pela crítica voraz as políticas de representação racial instaurada na sociedade brasileira.

\footnotetext{
19 Em vez de buscar a integração pura e simples, reivindica o direito de se inserir na sociedade brasileira sem a necessidade de desconsiderar os símbolos da negritude,ou seja, integração na diversidade cultural.
} 
Mesmo sem se transformar em partido político, o MNU politizou o cenário das relações raciais. Na década de 1980, a efervescência promovida pela abertura política, pelo movimento de diretas já, pelo debate da Constituinte e pelo centenário da abolição, eventos que impulsionaram a luta anti-racista, do ponto de vista político e onde o ativismo negro, enquanto movimento social teve grande participação. É a partir dessa atuação que a questão racial torna-se pauta dos partidos políticos, sobretudo os de centro-esquerda, onde a maior parte dos ativistas negros optou atuar.

Em 1984, o governo do Estado de São Paulo cria o primeiro órgão governamental do Brasil para tratar especificamente da questão racial. Ao Conselho de Participação e Desenvolvimento da Comunidade Negra do Estado de São Paulo, segue a criação da Fundação Cultural Palmares, órgão ligado ao governo federal.

A Constituição de 1988, promulgada no mesmo ano do centenário da abolição, inevitavelmente incorporou dispositivos antidiscriminatórios. A chamada "Constituição Cidadã" institucionaliza uma nova ordem jurídica mais democrática onde alguns pontos reivindicados pelo movimento negro são incorporados na forma de uma legislação antidiscriminatória.

\section{3 - Ações e discursos}

Nos anos 90 a luta de combate ao racismo é incrementada por mais ações governamentais. Em 1995, ano em que se celebrou o Tri-centenário da morte de 
Zumbi dos Palmares, ativistas do movimento negro marcharam em Brasília, onde foram recebidos pelo presidente da república Fernando Henrique Cardoso, que anuncia a criação o GTIVPN - Grupo de Trabalho Interministerial ${ }^{20}$ para a Valorização da População Negra.

Inaugura-se um período em que os temas sociais são recortados pela questão racial, as antigas reivindicações do movimento negro, tais como acesso à educação e a inserção no mercado de trabalho são as principais bandeiras. Mais mesmo que bandeiras começam ser delineadas como iniciativas que buscam ter um impacto concreto sobre a população negra.

Essas ações e os discursos se apresentam em dois formatos, o primeiro formato, apareceu também no discurso do presidente Fernando Henrique Cardoso, quando anunciou a criação do GTIVPN e diz respeito a políticas antidiscriminatórias. Como apontou Heringer (2001, p. 6) estas necessariamente não produzem igualdade de oportunidades. São políticas normalmente punitivas que operam no plano educativo, já que seu efeito no cotidiano pode promover mudança de comportamento e mentalidades.

Já o segundo formato é como política de combate as desigualdades raciais, no Brasil tratadas como políticas de ação afirmativa, em moldes parecidos a formulação norte-americana. Para o movimento negro esta perspectiva de ação aparece como mais eficiente na promoção da igualdade racial. Isto porque opera em situações concretas onde a desigualdade racial se apresenta, como por exemplo, no interior das universidades públicas ou nos altos escalões do governo.

\section{4 Histórico governamental.}

\footnotetext{
${ }^{20}$ A cerimônia de instalação do GTIVPN, ocorreu dois meses depois, em 27 de fevereiro de 1996.
} 
Desde o final do Império até muito recentemente, o Estado brasileiro teve um papel de liderança nesse pacto de silêncio e negação. A jovem república, proclamada e controlada por ex-senhores inconformados com a abolição da escravidão, inaugurou um padrão de exaltação oficial da herança indígena (subitamente elevada à condição de símbolo da brasilidade) e de desprezo pelos pretos e pelos mestiços (subitamente eleitos como responsáveis pela "indolência" e pelo "atraso" do país).

As teorias racistas pseudo-científicas do século XIX preconizavam uma rígida hierarquia das raças (os brancos no topo, com a responsabilidade de dominar e de "civilizar" as raças "inferiores") e condenavam veementemente a miscigenação como um fator de degeneração, fatal para o processo "civilizatório" e o "avanço" dos povos. A elite brasileira passou toda a Primeira República (18891930) assombrada por estas teorias, profundamente envergonhada de sua herança africana e ibérica, e da mestiçagem da população. Desenvolveu e financiou, com recursos públicos, vários projetos de atração de imigrantes europeus, não só em busca da mão de obra que considerava mais desejável, mas também em perseguição de um fantástico ideal de "embranquecimento nacional".

A chamada Revolução de 30 , supostamente modernizante e destinada a substituir no poder as velhas oligarquias da "velha república", nenhuma mudança trouxe na visão das elites ou na postura do Estado sobre a questão racial. O regime por ela implantado nutria, especialmente em sua fase ditatorial mais dura (o "Estado Novo", de 1937 a 1945), abertas simpatias pelos regimes nazifascistas que floresciam na Europa e por seu ideário racista de supremacia ariana. Macaqueando idéias e práticas do III Reich, desenvolvia projetos de educação física, ginástica e desportos voltados para a "eugenia" e a "melhoria da raça". Seu nacionalismo, sua estética oficial e sua busca de raízes "autênticas" incluía, mais uma vez, os indígenas e o folclore popular, mas não tinha lugar para os negros nem para o rico componente africano da cultura brasileira. Foi uma época marcada por avanços importantes na área dos direitos trabalhistas, pela 
supressão de liberdades políticas e graves violações dos direitos humanos, e por um completo descaso com relação às desigualdades raciais.

No plano das idéias, esse período assistiu o nascimento de uma reação intelectual contra o racismo "científico" e a tese da "danação nacional" pela mestiçagem. O grande protagonista desse movimento, o sociólogo pernambucano Gilberto Freyre, gerou forte comoção no pensamento social brasileiro ao fazer o elogio aberto da miscigenação, da herança cultural africana e do que chamou de "gênio colonial português". Sua obra, entretanto, é inteiramente impregnada por uma visão idílica, quase edênica, de uma suposta sociedade escravista patriarcal e pela mentira da escravidão benevolente ou cordial, e constitui, até hoje, o grande pilar intelectual do mito da democracia racial no Brasil.

Os governos populistas-desenvolvimentistas do interregno democrático 1945-1964 se preocuparam obsessivamente com a industrialização e o crescimento econômico. Com exceção das disparidades regionais, que mereceram alguma atenção, pouco se importaram com as iniqüidades sociais, e muito menos com seu componente racial. A grande efervescência reformista revolucionária do final desse período (governo João Goulart) moldou-se inteiramente por uma visão marxista da sociedade, baseada exclusivamente no modelo ortodoxo da luta de classes, sem nenhum espaço para considerações sobre gênero, raça, ou qualquer outra dimensão da desigualdade ou da justiça social.

A ditadura militar (1964 até o final dos anos 80) era totalmente refratária ao tema da desigualdade e promovia ativamente o mito da democracia racial. Os líderes e as organizações negras eram vistos com suspeição e foram muitas vezes perseguidos como esquerdistas ou "subversivos". A negação oficial do problema racial no Brasil atingiu seu ponto culminante, como anotamos acima, com a supressão do quesito sobre raça no Censo Demográfico de 1970. 
Aparentemente, o regime dos generais, tinha tanta convicção da "inocência" do Brasil nesta questão, que não teve nenhuma dificuldade em ratificar a Convenção 111 da OIT, a Convenção de 1960 da UNESCO contra a discriminação na educação, e a Convenção Geral das Nações Unidas para a Eliminação de Todas as Formas de Racismo (1966), ou mesmo em participar ativamente da condenação do Apartheid sul-africano nos fóruns internacionais e nas duas primeiras conferências mundiais contra o racismo.

Só no meado dos anos 80 , com o início da redemocratização, e um pouco mais tarde, com a nova Constituição Federal de 1988, começaram a surgir alguns sinais de mudança nesse quadro.

Partindo de São Paulo, em 1984, os novos governos estaduais democraticamente eleitos iniciaram a criação de agências e conselhos "da comunidade negra", com a missão de monitorar e combater a discriminação racial, de divulgar a cultura afro-brasileira e, de maneira meio vaga, de promover a inclusão e o progresso da população negra.

Essas iniciativas foram importantes, na medida em que significaram uma mudança de atitude, mas geraram poucos resultados concretos. As agências tinham mandatos mal definidos, financiamento inadequado e nenhum acesso aos centros reais de decisão. Permaneceram, quase sem exceção, como "guetos negros" encravados na estrutura dos respectivos governos. A comemoração do centenário da abolição, em 1988, ensejou alguma mobilização sobre temas afrobrasileiros, e resultou na criação, pelo governo José Sarney, da Fundação Cultural 
Palmares (assim denominada em homenagem ao Quilombo dos Palmares, o maior episódio de resistência escrava da história do Brasil) e na proclamação de seu líder, Zumbí dos Palmares, como herói nacional. A Constituição de 1988, que substituiu as cartas outorgadas pelos militares, além de expressar, em seu preâmbulo, o "reconhecimento da nação pela contribuição cultural" dos afrobrasileiros, redefiniu os atos de racismo e de discriminação racial como crimes, ao invés de contravenções, como eram tipificados na legislação anterior.

Em retrospectiva, a ação do Estado nesse período (meados dos 80 ao início dos 90) pode ser descrita como girando em torno de duas linhas principais: a. Uma vertente "cultural", que consistiu em uma crescente promoção e valorização da história, da cultura e da arte afro-brasileiras, enfatizando o conteúdo simbólico da resistência e da dignidade dos escravos (inclusive através do reconhecimento dos direitos das comunidades quilombolas às suas terras ancestrais).

Uma vertente de combate à discriminação, que envolveu um discreto incremento no aparato e na disposição do Estado para registrar e reprimir atos de discriminação racial flagrante, através de algumas medidas legislativas e do estabelecimento das agências, conselhos e ouvidorias acima mencionados.

Não houve, contudo, nenhuma admissão ou divulgação oficial das brutais desigualdades raciais (nem, é claro, da necessidade de enfrentá-las), ou qualquer ação concreta, nos campos da educação, do mercado de trabalho ou qualquer 
outro, no sentido de promover a redução das disparidades de renda, de educação, ou dos padrões de vida entre brancos e negros.

Mesmo sem querer diminuir a importância dos avanços conquistados nesta fase da transição para a democracia, é preciso observar que o período contém alguns ensinamentos importantes. Ele nos mostra, por exemplo, que é muito mais fácil construir consensos em torno da celebração da diversidade étnica, ou do orgulho pela herança cultural africana, do que se aventurar no terreno controvertido e conflituoso da ação afirmativa ou da discriminação positiva. Por mais importante que seja, a abordagem cultural é inofensiva, no sentido de não representar ameaça, pelo menos imediata, à ordem estabelecida, podendo, portanto, ser facilmente absorvida ou simplesmente ignorada.

Do mesmo modo, a condenação moral e, eventualmente, a punição de atos explícitos de discriminação nunca enfrentou nenhuma oposição séria no Brasil. Muito pelo contrário, os brasileiros têm um enorme apreço pela fantasia da democracia racial. As manifestações abertas de racismo e de intolerância racial, sobretudo em suas formas violentas, sempre foram claramente rejeitadas pela cultura brasileira contemporânea, e sua repressão sempre foi amplamente apoiada e aplaudida.

Bem diferente, e infinitamente mais difícil, é pressionar por oportunidades realmente iguais na educação e no mercado de trabalho, por mais médicos, advogados, juízes, empresários, cientistas, professores, diplomatas e generais negros. Isso implica em pressionar pela redistribuição da renda, da riqueza e do 
poder, e ameaça as próprias fundações de uma hierarquia econômica, social (e racial) estabelecida há séculos. É algo que os brasileiros estão muito menos propensos a fazer. Ou a aceitar.

A transição democrática se completou e se consolidou com a eleição de Fernando Henrique Cardoso, no final de 1994. Mais que qualquer de seus antecessores, o presidente eleito tinha.formação e motivação para incluir a questão racial na agenda de seu governo, portador que era de sólidas credenciais como sociólogo destacado, historiador da escravidão, estudioso das relações raciais, e importante liderança na luta pela democratização. Como um jovem pesquisador, teve um papel proeminente na demolição (acadêmica) do mito da democracia racial.

Fernando Henrique abordou o tema já em seu discurso de posse, apontando a desigualdade racial como um dos pilares fundadores da desigualdade no Brasil, e um problema a ser enfrentado com urgência e energia. Essa foi a primeira vez que um presidente brasileiro falou abertamente sobre esse tabú nacional. Alguns meses mais tarde, Brasília assistiu à maior manifestação pela igualdade racial jamais vista no país. A Esplanada dos Ministérios foi tomada por dezenas de milhares de manifestantes que exigiam posicionamento e ação do governo, na "Marcha Zumbí dos 13

O trabalho de Fernando Henrique Cardoso nessa área foi parte de um importante projeto sobre relações raciais no Brasil, comissionado pela UNESCO, nos anos 50, que teve a participação de notáveis cientistas sociais, como Roger 
Bastide, Octávio lanni, Ruth Leite Cardoso, e outros, coordenados por Florestan Fernandes. Gerou várias publicações, entre as quais Fernando Henrique Cardoso. Capitalismo e Escravidão no Brasil Meridional. O Negro na Sociedade Escravocrata do Rio Grande do Sul (1962). 2a. edição: Rio de Janeiro: Paz e Terra, 1977.

Apesar das expectativas que cercaram seu nascimento, o Grupo de Trabalho Interministerial da População Negra (GTI População Negra), teve um destino bem semelhante ao dos seus antecessores nos níveis estadual e local, basicamente pelo mesmo conjunto de razões: definições genéricas e vagas, falta de foco, problemas de financiamento e, acima de tudo, nenhuma autoridade ou peso político real.

O grupo realizou várias reuniões e obteve algumas vitórias, particularmente na eliminação de estereótipos e abordagens racistas dos currículos e livros escolares, mas pouco conseguiu avançar além disso.

O desdém brasileiro pela desigualdade racial prevaleceu mais uma vez, e logo ficou evidente que a maior parte dos ministérios e das agências governamentais envolvidas encaravam o GTI População Negra mais como um aborrecimento do que como uma prioridade. O Primeiro Plano Nacional de Direitos Humanos (PNDH I), lançado em 1996, incluiu um capítulo sobre a questão racial, todavia seu foco principal estava voltado para a promoção de outros aspectos dos direitos humanos. O Ministério do Trabalho lançou, na mesma época, um conjunto de programas destinados a combater a discriminação no 
mercado laboral, que também incluía a discriminação racial entre seus alvos, mas que, a exemplo da área de direitos humanos, terminou por priorizar outros enfoques, enfatizando as questões de gênero e os problemas dos portadores de deficiências.

Um balanço retrospectivo dos parcos resultados, tanto do GTI População Negra quanto das demais iniciativas ensaiadas, deixa claro que o desempenho do primeiro mandato de Fernando Henrique Cardoso no campo dos problemas raciais foi, de fato, muito pobre, e inevitavelmente frustrante em comparação com as altas expectativas que haviam sido levantadas. Mesmo assim, o presidente inaugurou uma era de abertura e transparência na atitude do Estado brasileiro com relação às desigualdades raciais e ao racismo, que iria produzir frutos importantes logo adiante, com o auxílio da convocação, pelas Nações Unidas, da III Conferência Mundial contra o Racismo.

A Conferência de Durban coincidiu com seu segundo mandato e contribuiu decisivamente para impulsionar o tema na agenda nacional. A preparação para Durban, a própria conferência, e seus desdobramentos geraram uma autêntica escalada na mobilização e na tomada de consciência, dentro do governo, na mídia e, em menor escala, na própria sociedade, desencadeando uma sucessão de eventos que colocou a questão da raça e da igualdade racial em um patamar inédito na história do Brasil moderno.

Um novo padrão de diálogo entre o governo e a sociedade civil foi estabelecido, com a criação de comissões paritárias e a realização de várias 
rodadas de reuniões, consultas e eventos em todas as regiões do país. A intensidade da participação da sociedade no processo preparatório pode ser inferida pelo tamanho da delegação brasileira presente em Durban, que reuniu mais de 500 pessoas, entre delegados oficiais e membros de organizações nãogovernamentais. 15

O governo brasileiro adotou, pela primeira vez na história, uma postura de absoluta transparência e de divulgação ativa e realista das desigualdades raciais. Com o apoio e o estímulo pessoal do Presidente da República, o IPEA iniciou a produção regular de indicadores e de análises desagregadas por raça, conferindo precisão estatística e chancela oficial ao dramático quadro tantas vezes denunciado sem sucesso pela militância negra. Uma política deliberada de ampla divulgação desses dados conseguiu captar a atenção da grande imprensa e da opinião pública, e contribuiu significativamente para o "empowerment" das organizações do movimento negro, que passaram a tê-los como referência em suas denúncias e reivindicações.

$\mathrm{Na}$ conferência regional preparatória, em Santiago, e novamente em Durban, o Brasil teve um papel protagonista, com posições avançadas em vários temas. Admitiu, pela primeira vez perante fóruns internacionais, a existência de formas estruturais de racismo no país e apoiou a resolução reconhecendo a escravidão e o tráfico de escravos como crimes contra a humanidade, bem como a tese da reparação aos descendentes das vítimas da escravidão através de políticas compensatórias focalizadas. Entre essas políticas, o documento oficial brasileiro propunha explicitamente, com a aprovação pessoal do presidente 
Fernando Henrique, a política de quotas para afrodescendentes nas universidades.

Na esteira de Durban, o debate sobre a questão racial entrou na agenda nacional com uma força sem precedentes, atraindo mais atenção dos governos (executivo, legislativo e judiciário, nos níveis federal, estadual e municipal), mais cobertura da mídia e mais participação do público em geral, do que em qualquer época anterior. O período assistiu a criação do Conselho Nacional de Combate à Discriminação (CNCD), com representantes do governo e da sociedade civil, assim como a entrada em cena de novos e importantes atores. O Ministério Público Federal, o Ministério Público do Trabalho e o Tribunal Superior do Trabalho intensificaram muito suas ações nessa área, adotando posturas crescentemente ativas contra a discriminação e pela promoção da igualdade racial.

Registrou-se também um sensível aumento de interesse sobre o tema no âmbito do legislativo, com apresentação e discussão de vários projetos de lei, tanto no Congresso Nacional como nas assembléias estaduais e câmaras municipais.

Ainda no ano de 2001 ocorreram os primeiros experimentos brasileiros com programas de ação afirmativa envolvendo a discriminação positiva de afrodescendentes.

Os ministérios do Desenvolvimento Agrário, da Justiça e da Cultura, e o Tribunal Superior do Trabalho lançaram projetos piloto visando ampliar a 
participação de negros nas funções comissionadas de direção e assessoramento (DAS) e começaram a exigir políticas de diversidade racial de seus fornecedores de bens e serviços.

Em 20 de novembro de 2001, o então presidente do Supremo Tribunal Federal, Ministro Marco Aurélio Mello, surpreendeu a nação com uma calorosa defesa pública da ação afirmativa, sustentando, em um pronunciamento memorável, a tese de que a Constituição Federal não apenas garante suporte legal como também positivamente induz essa linha de políticas públicas, na medida em que determina ao Estado a promoção ativa da igualdade socioeconômica entre todos os brasileiros. 16

O Ministério das Relações Exteriores (Itamaraty) iniciou um programa de bolsas destinado a reforçar a preparação de candidatos negros ao disputado exame de admissão ao Instituto Rio Branco, a academia brasileira do serviço diplomático. Essa iniciativa abriga, além de sua óbvia importância intrínseca, um significado simbólico de grande envergadura.

Apesar de existirem alguns negros na carreira diplomática, o Brasil nunca teve, em toda a sua história, um embaixador de carreira negro. O Itamaraty sempre foi visto como um reduto conservador exclusivo da elite branca e foi muitas vezes acusado no passado de tentar projetar para o mundo uma imagem "branca" do país.

Embora essas acusações já não tenham, há bastante tempo, qualquer fundamento real, o fato de que a presença de negros e negras nos quadros da 
diplomacia brasileira, principalmente em seus escalões superiores, é extremamente rarefeita, segue sendo absolutamente verdadeiro. A decisão do MRE de reconhecer o problema e de enfrentá-lo abertamente denota uma nova postura e uma transparência ainda muito raras no serviço público ena sociedade brasileira.

Um decreto presidencial de 13 de maio de 2002 criou o Programa Nacional de Ações Afirmativas com o objetivo de estender ao conjunto do governo federal os projetos piloto lançados pelos ministérios acima mencionados, através do estabelecimento de quotas quantitativas para afrodescendentes e para mulheres nos cargos superiores de direção e assessoramento de toda a administração do poder executivo federal. Sua implementação foi iniciada no final de 2002, com a realização do Censo Racial do Serviço Público Federal, cujos resultados ainda não foram divulgados.

Todos esses avanços foram importantes, mas, em virtude de seu caráter localizado incipiente, passaram quase inteiramente despercebidos pelo grande público e não geraram grandes controvérsias ou oposição. No Brasil, como em outros lugares, o privilégio de sacudir a opinião pública e deflagrar debates amplos e acirrados estava reservado à questão das quotas raciais nas universidades, como se verá adiante.

O presidente Luís Inácio Lula da Silva tomou posse em janeiro de 2003, em meio a uma imensa onda de expectativa e de esperança. Chegou ao poder com um discurso altamente crítico ao governo anterior, a promessa de transformações 
profundas na vida nacional e uma história de vida -nordestino, de origem humilde, líder sindical metalúrgico- que o credenciava a encarnar a imagem de grandes mudanças: é o primeiro presidente brasileiro nascido e formado ao largo das elites tradicionais.

Embora tenha adotado políticas econômicas (de ortodoxia monetária e fiscal) idênticas às do governo que tanto criticava, com reflexos duramente negativos sobre a atividade econômica e o emprego, os projetos que declarou prioritários a completa erradicação da fome, as reformas previdenciária e tributária, e a retomada do "espetáculo" do crescimento econômico- continuam sustentando, e até reforçaram, a expectativa de mudanças.

As primeiras atitudes do novo governo com relação à questão racial foram claramente positivas. Seu ministério incluiu três ministros negros (da Cultura, da Assistência Social e do Meio Ambiente) e, em março de 2003, foi criada uma secretaria especial, com status ministerial, para a elaboração e a coordenação de políticas de promoção da igualdade racial. Para esta secretaria (SEPPIR) foi nomeada uma mulher negra com credenciais impecáveis de militância na luta da comunidade afro-brasileira. Em maio, ao indicar o jurista Joaquim Barbosa para o Supremo Tribunal Federal, o presidente fez história, colocando o primeiro ministro negro na mais alta corte de justiça do país.

Um bom começo, sem dúvida. Mas é preciso observar que esses atos, em si, não asseguram aadoção, e muito menos o sucesso, de políticas eficazes para a redução das desigualdades raciais. A experiência demonstra fartamente, em 
todas as partes do mundo, que a criação de órgãos, agências ou comissões, mesmo em alto nível hierárquico, nada garante por si só.

No caso específico da lutacontra a discriminação e pela igualdade racial no Brasil, a história recente, esboçada acima, é rica em frustrações e em lições que não devem ser ignoradas. Muito além da mera criação dos órgãos, é preciso garantir sua inserção real nos centros de decisão, sua influência política e os recursos humanos e materiais necessários à sua atuação. Nada disso está claro no caso presente.

A opção por ações afirmativas (políticas que envolvam discriminação positiva a favor da população negra) está longe de ser consensual ou tranquila dentro do governo ou dentro do partido do governo. É óbvia, por exemplo, e muito preocupante, a posição vacilante do Ministério da Educação na questão de quotas raciais nas universidades públicas. Ou os pesados ataques lançados há pouco tempo contra o próprio conceito de políticas sociais focalizadas (do qual as ações afirmativas são um caso particular) por intelectuais orgânicos altamente influentes no partido do governo.

O mais importante avanço a registrar em 2003 é o progresso do debate sobre ações afirmativas no âmbito das universidades. Ele se deve, ao lado da ação do governo federal (iniciada no mandato anterior e continuada no atual), à intensificação da atuação do movimento negro, a mobilizações específicas de grupos e de governos locais, e tem como pano de fundo o novo patamar de consciência e de visibilidade das desigualdades raciais que se construiu nos 
últimos anos, sobretudo a partir da Conferência de Durban e seus desdobramentos.

Nos dois últimos anos várias universidades públicas brasileiras haviam começado, finalmente, a discutir a possibilidade de incluir critérios de ação afirmativa para negros, ou outros mecanismos de inclusão étnica e social em geral, em seus sistemas de admissão aos cursos de graduação. Algumas já vinham, há algum tempo, reservando vagas para candidatos indígenas ou portadores de deficiências físicas.

No início de 2003 esse processo teve grande aceleração com a introdução, pelas universidades estaduais do Rio de Janeiro (Universidade do Estado do Rio de Janeiro -UERJ e Universidade Estadual Norte Fluminense- UENF) e pela Universidade do Estado da Bahia (UNEB), de quotas para afrodescendentes em seus exames vestibulares. Nos dois casos o critério racial se combinou com um critério sócioeconômico, representado pelo requisito do candidato ser oriundo de escola secundária pública, numa tentativa de colocar um foco mais preciso nos estratos de renda mais baixa.

A experiência produziu instantâneamente um debate acirrado, com ampla cobertura da grande imprensa e das redes nacionais de televisão. A "quota" passou a ser assunto em toda parte: pela primeira vez se viu nas ruas, nos bares, nos aeroportos e nas filas dos bancos, pessoas discutindo acaloradamente os "prós" e os "contras" da ação afirmativa. Desencadeou também várias disputas judiciais, algumas das quais já chegaram ao Supremo Tribunal Federal, que dentro de pouco tempo terá a oportunidade de confirmar, ou de rejeitar, a posição amplamente divulgada de seu ex-presidente. 
No dia 6 de junho de 2003, a Universidade de Brasília (UnB) tornou-se a primeira universidade federal brasileira a aprovar um projeto de ação afirmativa, reservando uma quota de $20 \%$ das vagas para candidatos negros, a ser aplicada já no vestibular de 2004 .

O projeto terá a duração inicial de 10 anos, e prevê ainda uma quota, a ser definida, para candidatos indígenas. A decisão da UnB foi tomada de maneira inteiramente autônoma por sua Coordenação de Ensino, Pesquisa e Extensão (por 24 votos a favor, um contrário e uma abstenção), sem nenhuma participação do Ministério da Educação ou do Conselho Federal de Educação.17 A Universidade Federal de Alagoas (UFAL) também já decidiu adotar um programa de quotas para afrodescendentes e há mobilizações e propostas de ações afirmativas em curso, em diferentes estágios de desenvolvimento, nas universidades federais da Bahia (UFBA), Minas Gerais (UFMG), Fluminense (UFF), São Paulo (UNIFESP), Paraná (UFPR), Goiás (UFG), Amazonas (UFAM), Amapá (UNIFAP), Roraima (UFRR), e provavelmente em outras.

No setor das universidades públicas estaduais, além das pioneiras UERJ, UENF e UNEB, o movimento se estende a várias outras, como a Universidade do Estado do Mato Grosso (UNEMAT), que já mantém uma política de quotas para indígenas, a Universidade do Estado de Minas Gerais (UEMG), e a Universidade do Estado de Santa Catarina (UDESC). O governo do estado de São Paulo, cujo sistema universitário estadual (constituído pela Universidade de São Paulo - USP, Universidade Estadual de Campinas - UNICAMP e Universidade do Estado de São Paulo - UNESP) é o maior e mais prestigiado do país, está estudando a 
adoção de políticas afirmativas no conjunto das três universidades. Sua Secretaria de Justiça e de Defesa da Cidadania criou uma Comissão de Promoção das Ações Afirmativas, vai realizar um censo racial dos servidores públicos do estado e já iniciou uma ampla programação de workshops e congressos focalizando a questão da inclusão racial.

Essas mobilizações, especialmente o modelo de decisão independente inaugurado pela UnB, indicam que o processo adquiriu dinâmica e autonomia próprias e já começam a produzir resultados, rompendo o imobilismo do Ministério da Educação. Foi em resposta a essas pressões que o Ministro da Educação e a Secretária Especial de Políticas de Promoção da Igualdade Racial publicaram a Portaria Conjunta no. 2.430, em 9 de setembro de 2003, criando um Grupo de Trabalho "com o objetivo de elaborar proposta para o estabelecimento de políticas públicas de ação afirmativa que permitam o acesso e a permanência de negros nas instituições federais de ensino superior".18

É também visível a maior atenção dos escritórios brasileiros das agências do sistema das Nações Unidas para o tema das desigualdades raciais e as políticas de inclusão racial nos últimos anos. O PNUD estabeleceu desde 2001 um programa de cooperação com o IPEA para a produção de estudos e estatísticas sobre a questão. A OIT produziu um extenso relatório sobre discriminação de gênero e de raça no mercado brasileiro de trabalho (em 2003) e a UNESCO criou em seu staff brasileiro um ponto focal sobre os problemas raciais. 
O ano de 2003 assistiu ainda às primeiras movimentações do setor empresarial privado nessa área. Em agosto, a ONG empresarial Integrare, a American Chamber of Commerce de São Paulo e a Congressional Black Caucus Foundation (dos Estados Unidos) realizaram um interessante seminário sobre inclusão racial através dos negócios, com a participação de empresários negros norte-americanos e brasileiros e a apresentação de cases de programas de ação afirmativa no ambiente corporativo.

Desde o final do Império até muito recentemente, o Estado brasileiro teve um papel de liderança nesse pacto de silêncio e negação. A jovem república, proclamada e controlada por ex-senhores inconformados com a abolição da escravidão, inaugurou um padrão de exaltação oficial da herança indígena (subitamente elevada à condição de símbolo da brasilidade) e de desprezo pelos pretos e pelos mestiços (subitamente eleitos como responsáveis pela "indolência" e pelo "atraso" do país).

As teorias racistas pseudo-científicas do século XIX preconizavam uma rígida hierarquia das raças (os brancos no topo, com a responsabilidade de dominar e de "civilizar" as raças "inferiores") e condenavam veementemente a miscigenação como um fator de degeneração, fatal para o processo "civilizatório" e o "avanço" dos povos. A elite brasileira passou toda a Primeira República (18891930) assombrada por estas teorias, profundamente envergonhada de sua herança africana e ibérica, e da mestiçagem da população. Desenvolveu e financiou, com recursos públicos, vários projetos de atração de imigrantes europeus, não só em busca da mão de obra que considerava mais desejável, mas também em perseguição de um fantástico ideal de "embranquecimento nacional".

A chamada Revolução de 30 , supostamente modernizante e destinada a substituir no poder as velhas oligarquias da "velha república", nenhuma mudança trouxe na visão das elites ou na postura do Estado sobre a questão racial. O 
regime por ela implantado nutria, especialmente em sua fase ditatorial mais dura (o "Estado Novo", de 1937 a 1945), abertas simpatias pelos regimes nazifascistas que floresciam na Europa e por seu ideário racista de supremacia ariana. Macaqueando idéias e práticas do III Reich, desenvolvia projetos de educação física, ginástica e desportos voltados para a "eugenia" e a "melhoria da raça". Seu nacionalismo, sua estética oficial e sua busca de raízes "autênticas" incluía, mais uma vez, os indígenas e o folclore popular, mas não tinha lugar para os negros nem para o rico componente africano da cultura brasileira. Foi uma época marcada por avanços importantes na área dos direitos trabalhistas, pela supressão de liberdades políticas e graves violações dos direitos humanos, e por um completo descaso com relação às desigualdades raciais.

No plano das idéias, esse período assistiu o nascimento de uma reação intelectual contra o racismo "científico" e a tese da "danação nacional" pela mestiçagem. O grande protagonista desse movimento, o sociólogo pernambucano Gilberto Freyre, gerou forte comoção no pensamento social brasileiro ao fazer o elogio aberto da miscigenação, da herança cultural africana e do que chamou de "gênio colonial português". Sua obra, entretanto, é inteiramente impregnada por uma visão idílica, quase edênica, de uma suposta sociedade escravista patriarcal e pela mentira da escravidão benevolente ou cordial, e constitui, até hoje, o grande pilar intelectual do mito da democracia racial no Brasil.

Os governos populistas-desenvolvimentistas do interregno democrático 1945-1964 se preocuparam obsessivamente com a industrialização e o crescimento econômico. Com exceção das disparidades regionais, que mereceram alguma atenção, pouco se importaram com as iniqüidades sociais, e muito menos com seu componente racial. A grande efervescência reformista revolucionária do final desse período (governo João Goulart) moldou-se inteiramente por uma visão marxista da sociedade, baseada exclusivamente no modelo ortodoxo da luta de classes, sem nenhum espaço para considerações sobre gênero, raça, ou qualquer outra dimensão da desigualdade ou da justiça social. 
A ditadura militar (1964 até o final dos anos 80) era totalmente refratária ao tema da desigualdade e promovia ativamente o mito da democracia racial. Os líderes e as organizações negras eram vistos com suspeição e foram muitas vezes perseguidos como esquerdistas ou "subversivos". A negação oficial do problema racial no Brasil atingiu seu ponto culminante, como anotamos acima, com a supressão do quesito sobre raça no Censo Demográfico de 1970.

Aparentemente, o regime dos generais, tinha tanta convicção da "inocência" do Brasil nesta questão, que não teve nenhuma dificuldade em ratificar a Convenção 111 da OIT, a Convenção de 1960 da UNESCO contra a discriminação na educação, e a Convenção Geral das Nações Unidas para a Eliminação de Todas as Formas de Racismo (1966), ou mesmo em participar ativamente da condenação do Apartheid sul-africano nos fóruns internacionais e nas duas primeiras conferências mundiais contra o racismo.

Só no meado dos anos 80, com o início da redemocratização, e um pouco mais tarde, com a nova Constituição Federal de 1988, começaram a surgir alguns sinais de mudança nesse quadro.

Partindo de São Paulo, em 1984, os novos governos estaduais democraticamente eleitos iniciaram a criação de agências e conselhos "da comunidade negra", com a missão de monitorar e combater a discriminação racial, de divulgar a cultura afro-brasileira e, de maneira meio vaga, de promover a inclusão e o progresso da população negra. 
Essas iniciativas foram importantes, na medida em que significaram uma mudança de atitude, mas geraram poucos resultados concretos. As agências tinham mandatos mal definidos, financiamento inadequado e nenhum acesso aos centros reais de decisão. Permaneceram, quase sem exceção, como "guetos negros" encravados na estrutura dos respectivos governos. A comemoração do centenário da abolição, em 1988, ensejou alguma mobilização sobre temas afrobrasileiros, e resultou na criação, pelo governo José Sarney, da Fundação Cultural Palmares (assim denominada em homenagem ao Quilombo dos Palmares, o maior episódio de resistência escrava da história do Brasil) e na proclamação de seu líder, Zumbí dos Palmares, como herói nacional. A Constituição de 1988, que substituiu as cartas outorgadas pelos militares, além de expressar, em seu preâmbulo, o "reconhecimento da nação pela contribuição cultural" dos afrobrasileiros, redefiniu os atos de racismo e de discriminação racial como crimes, ao invés de contravenções, como eram tipificados na legislação anterior.

Em retrospectiva, a ação do Estado nesse período (meados dos 80 ao início dos 90) pode ser descrita como girando em torno de duas linhas principais: a. Uma vertente "cultural", que consistiu em uma crescente promoção e valorização da história, da cultura e da arte afro-brasileiras, enfatizando o conteúdo simbólico da resistência e da dignidade dos escravos (inclusive através do reconhecimento dos direitos das comunidades quilombolas às suas terras ancestrais).

Uma vertente de combate à discriminação, que envolveu um discreto incremento no aparato e na disposição do Estado para registrar e reprimir atos de 
discriminação racial flagrante, através de algumas medidas legislativas e do estabelecimento das agências, conselhos e ouvidorias acima mencionados.

Não houve, contudo, nenhuma admissão ou divulgação oficial das brutais desigualdades raciais (nem, é claro, da necessidade de enfrentá-las), ou qualquer ação concreta, nos campos da educação, do mercado de trabalho ou qualquer outro, no sentido de promover a redução das disparidades de renda, de educação, ou dos padrões de vida entre brancos e negros.

Mesmo sem querer diminuir a importância dos avanços conquistados nesta fase da transição para a democracia, é preciso observar que o período contém alguns ensinamentos importantes. Ele nos mostra, por exemplo, que é muito mais fácil construir consensos em torno da celebração da diversidade étnica, ou do orgulho pela herança cultural africana, do que se aventurar no terreno controvertido e conflituoso da ação afirmativa ou da discriminação positiva. Por mais importante que seja, a abordagem cultural é inofensiva, no sentido de não representar ameaça, pelo menos imediata, à ordem estabelecida, podendo, portanto, ser facilmente absorvida ou simplesmente ignorada.

Do mesmo modo, a condenação moral e, eventualmente, a punição de atos explícitos de discriminação nunca enfrentou nenhuma oposição séria no Brasil. Muito pelo contrário, os brasileiros têm um enorme apreço pela fantasia da democracia racial. As manifestações abertas de racismo e de intolerância racial, sobretudo em suas formas violentas, sempre foram claramente rejeitadas pela 
cultura brasileira contemporânea, e sua repressão sempre foi amplamente apoiada e aplaudida.

Bem diferente, e infinitamente mais difícil, é pressionar por oportunidades realmente iguais na educação e no mercado de trabalho, por mais médicos, advogados, juízes, empresários, cientistas, professores, diplomatas e generais negros. Isso implica em pressionar pela redistribuição da renda, da riqueza e do poder, e ameaça as próprias fundações de uma hierarquia econômica, social (e racial) estabelecida há séculos. É algo que os brasileiros estão muito menos propensos a fazer. Ou a aceitar.

A transição democrática se completou e se consolidou com a eleição de Fernando Henrique Cardoso, no final de 1994. Mais que qualquer de seus antecessores, o presidente eleito tinha.formação e motivação para incluir a questão racial na agenda de seu governo, portador que era de sólidas credenciais como sociólogo destacado, historiador da escravidão, estudioso das relações raciais, e importante liderança na luta pela democratização. Como um jovem pesquisador, teve um papel proeminente na demolição (acadêmica) do mito da democracia racial.

Fernando Henrique abordou o tema já em seu discurso de posse, apontando a desigualdade racial como um dos pilares fundadores da desigualdade no Brasil, e um problema a ser enfrentado com urgência e energia. Essa foi a primeira vez que um presidente brasileiro falou abertamente sobre esse tabú nacional. Alguns meses mais tarde, Brasília assistiu à maior manifestação 
pela igualdade racial jamais vista no país. A Esplanada dos Ministérios foi tomada por dezenas de milhares de manifestantes que exigiam posicionamento e ação do governo, na "Marcha Zumbí dos 13

O trabalho de Fernando Henrique Cardoso nessa área foi parte de um importante projeto sobre relações raciais no Brasil, comissionado pela UNESCO, nos anos 50, que teve a participação de notáveis cientistas sociais, como Roger Bastide, Octávio lanni, Ruth Leite Cardoso, e outros, coordenados por Florestan Fernandes. Gerou várias publicações, entre as quais Fernando Henrique Cardoso. Capitalismo e Escravidão no Brasil Meridional. O Negro na Sociedade Escravocrata do Rio Grande do Sul (1962). 2a. edição: Rio de Janeiro: Paz e Terra, 1977.

Apesar das expectativas que cercaram seu nascimento, o Grupo de Trabalho Interministerial da População Negra (GTI População Negra), teve um destino bem semelhante ao dos seus antecessores nos níveis estadual e local, basicamente pelo mesmo conjunto de razões: definições genéricas e vagas, falta de foco, problemas de financiamento e, acima de tudo, nenhuma autoridade ou peso político real.

O grupo realizou várias reuniões e obteve algumas vitórias, particularmente na eliminação de estereótipos e abordagens racistas dos currículos e livros escolares, mas pouco conseguiu avançar além disso.

O desdém brasileiro pela desigualdade racial prevaleceu mais uma vez, e logo ficou evidente que a maior parte dos ministérios e das agências 
governamentais envolvidas encaravam o GTI População Negra mais como um aborrecimento do que como uma prioridade. O Primeiro Plano Nacional de Direitos Humanos (PNDH I), lançado em 1996, incluiu um capítulo sobre a questão racial, todavia seu foco principal estava voltado para a promoção de outros aspectos dos direitos humanos. O Ministério do Trabalho lançou, na mesma época, um conjunto de programas destinados a combater a discriminação no mercado laboral, que também incluía a discriminação racial entre seus alvos, mas que, a exemplo da área de direitos humanos, terminou por priorizar outros enfoques, enfatizando as questões de gênero e os problemas dos portadores de deficiências.

Um balanço retrospectivo dos parcos resultados, tanto do GTI População Negra quanto das demais iniciativas ensaiadas, deixa claro que o desempenho do primeiro mandato de Fernando Henrique Cardoso no campo dos problemas raciais foi, de fato, muito pobre, e inevitavelmente frustrante em comparação com as altas expectativas que haviam sido levantadas. Mesmo assim, o presidente inaugurou uma era de abertura e transparência na atitude do Estado brasileiro com relação às desigualdades raciais e ao racismo, que iria produzir frutos importantes logo adiante, com o auxílio da convocação, pelas Nações Unidas, da III Conferência Mundial contra o Racismo.

A Conferência de Durban coincidiu com seu segundo mandato e contribuiu decisivamente para impulsionar o tema na agenda nacional. A preparação para Durban, a própria conferência, e seus desdobramentos geraram uma autêntica escalada na mobilização e na tomada de consciência, dentro do governo, na mídia 
e, em menor escala, na própria sociedade, desencadeando uma sucessão de eventos que colocou a questão da raça e da igualdade racial em um patamar inédito na história do Brasil moderno.

Um novo padrão de diálogo entre o governo e a sociedade civil foi estabelecido, com a criação de comissões paritárias e a realização de várias rodadas de reuniões, consultas e eventos em todas as regiões do país. A intensidade da participação da sociedade no processo preparatório pode ser inferida pelo tamanho da delegação brasileira presente em Durban, que reuniu mais de 500 pessoas, entre delegados oficiais e membros de organizações nãogovernamentais. 15

O governo brasileiro adotou, pela primeira vez na história, uma postura de absoluta transparência e de divulgação ativa e realista das desigualdades raciais. Com o apoio e o estímulo pessoal do Presidente da República, o IPEA iniciou a produção regular de indicadores e de análises desagregadas por raça, conferindo precisão estatística e chancela oficial ao dramático quadro tantas vezes denunciado sem sucesso pela militância negra. Uma política deliberada de ampla divulgação desses dados conseguiu captar a atenção da grande imprensa e da opinião pública, e contribuiu significativamente para o "empowerment" das organizações do movimento negro, que passaram a tê-los como referência em suas denúncias e reivindicações.

$\mathrm{Na}$ conferência regional preparatória, em Santiago, e novamente em Durban, o Brasil teve um papel protagonista, com posições avançadas em vários 
temas. Admitiu, pela primeira vez perante fóruns internacionais, a existência de formas estruturais de racismo no país e apoiou a resolução reconhecendo a escravidão e o tráfico de escravos como crimes contra a humanidade, bem como a tese da reparação aos descendentes das vítimas da escravidão através de políticas compensatórias focalizadas. Entre essas políticas, o documento oficial brasileiro propunha explicitamente, com a aprovação pessoal do presidente Fernando Henrique, a política de quotas para afrodescendentes nas universidades.

Na esteira de Durban, o debate sobre a questão racial entrou na agenda nacional com uma força sem precedentes, atraindo mais atenção dos governos (executivo, legislativo e judiciário, nos níveis federal, estadual e municipal), mais cobertura da mídia e mais participação do público em geral, do que em qualquer época anterior. O período assistiu a criação do Conselho Nacional de Combate à Discriminação (CNCD), com representantes do governo e da sociedade civil, assim como a entrada em cena de novos e importantes atores. O Ministério Público Federal, o Ministério Público do Trabalho e o Tribunal Superior do Trabalho intensificaram muito suas ações nessa área, adotando posturas crescentemente ativas contra a discriminação e pela promoção da igualdade racial.

Registrou-se também um sensível aumento de interesse sobre o tema no âmbito do legislativo, com apresentação e discussão de vários projetos de lei, tanto no Congresso Nacional como nas assembléias estaduais e câmaras municipais. 
Ainda no ano de 2001 ocorreram os primeiros experimentos brasileiros com programas de ação afirmativa envolvendo a discriminação positiva de afrodescendentes.

\section{CONSIDERAÇÕES CONCLUSIVAS}

A permanência de tamanhas desigualdades raciais, especialmente ao longo de períodos de efetivo progresso social para o conjunto do país, encerra algumas lições importantes e desmente algumas crenças falaciosas. A esperança generalizada de que o crescimento econômico, o desenvolvimento social e, sobretudo, o retorno à democracia depois de duas décadas de ditadura militar reduziriam naturalmente as desigualdades raciais (e as disparidades sociais, em geral) se revelou tristemente infundada.

Como vimos acima, durante a primeira fase do Plano Real (1994-1998) a renda domiciliar real per capita cresceu quase $30 \%$, e a renda real média do trabalho cresceu $26 \%$ (com relação ao nível de 1993). A proporção de pobres, por outro lado, caiu mais de 9 pontos percentuais no mesmo período, fazendo com que pelo menos 11 milhões de pessoas ultrapassassem o limiar da linha de pobreza. Vimos também que, apesar das oscilações econômicas dos anos seguintes, essas conquistas não foram revertidas e se mantiveram até o final da década. 
Em outras importantes áreas o progresso foi ainda maior e mais sustentado. O gasto social do Governo Federal cresceu $40 \%$ em termos reais entre 1993 e 1998, atingindo a marca de 14\% do PIB brasileiro, e permaneceu nesse patamar até o final do mandato de Fernando Henrique Cardoso. Os avanços na educação e na saúde foram notáveis, por qualquer padrão de medida. A taxa de mortalidade infantil caiu de 39 por mil, em 1991, para 32 por mil, em 2000. A porcentagem de crianças de 7 a 13 anos que não frequentam a escola declinou de 12, em 1992, para 2,9 em 2001, para mencionar apenas alguns exemplos.

A redemocratização foi completa, com eleições absolutamente livres, ampla liberdade de expressão e de organização política e social, e trouxe uma significativa ampliação da participação da sociedade civil no processo político.

Essas mudanças beneficiaram, como vimos, toda a população, mas as grandes disparidades entre brancos e negros permaneceram praticamente intocadas, e até aumentaram em alguns casos.

O que a história brasileira recente nos revela é, portanto, a extrema limitação das políticas sociais ditas "universalistas" no que se refere à sua capacidade de reduzir desigualdades, ou de reverter as consequências de exclusões passadas. Ela sugere enfaticamente que a igualdade não se produz naturalmente, e que as desigualdades que foram historicamente construídas (e consolidadas ao longo de séculos) tem que ser ativamente desconstruídas, através de deliberação consciente da sociedade e de instrumentos políticos adequados e eficazes. Em particular, a experiência dos anos 90 demonstra a necessidade de adotar políticas focalizadas de promoção da igualdade, oferecendo, através de discriminação positiva, compensações para os grupos negativamente discriminados e excluídos no passado, visando restabelecer (ou estabelecer) condições de competição verdadeiramente igualitárias.

As regras de competição social e as noções de justiça competitiva (especialmente o princípio da estrita "igualdade de todos perante a lei") 
dominantes em nossa cultura ainda são aquelas herdadas do liberalismo clássico (tanto político quanto econômico). São essencialmente os códigos do mercado liberal, que preconizam a completa "neutralidade" ou "isenção" do Estado diante dos competidores. Essas regras não são, obviamente, capazes de produzir a igualdade como resultado. Muito pelo contrário, elas têm a igualdade como um pressuposto: expressam, o ideal de justiça de uma república abstrata, de cidadãos abstratos, teoricamente iguais. São fundamentalmente a-históricas e seriam justas, talvez, em uma sociedade hipotética, onde as pessoas fossem rigorosamente iguais. Ou seja, em uma sociedade que nunca existiu. Em sociedades como a brasileira, onde as pessoas são brutalmente desiguais, elas são simplesmente hipócritas e tem como resultado a perpetuação e a ampliação das diferenças.

A essência da chamada "ação afirmativa" é, portanto, simplesmente, a decisão consciente da sociedade de colocar limites à "lei do mais forte", e tratar os desiguais de maneira desigual, com o objetivo de promover a igualdade.100 principal obstáculo à adoção de tais políticas no Brasil tem sido, até o presente (juntamente com uma tolerância quase inacreditável da sociedade com relação à desigualdade em geral) uma persistente negação da própria questão racial. A sociedade brasileira se recusa a admitir a existência de qualquer forma de preconceito ou discriminação racial, a reconhecer que o país possa ter qualquer tipo de "problema racial" e, é claro, que a nação seja devedora de qualquer reparação à sua população negra. A mera discussão da questão enfrenta resistências generalizadas.

Como apontamos anteriormente, a miscigenação, o relacionamento "cordial" entre as raças, os níveis relativamente baixos de violência interracial e de manifestações abertas de racismo, e a ausência de segregação legal ou explícita (que são traços verdadeiros e positivos da sociedade brasileira), faz com que a maioria dos brasileiros brancos tenda a subestimar, ou mesmo a descartar inteiramente, o papel do componente racial na geração e na manutenção dos altíssimos níveis de desigualdade que se observam no país. Apesar de conviver 
cotidianamente com disparidades flagrantes e permanentemente reiteradas, grande parte dos brasileiros ainda se apega tenazmente ao mito, profundamente arraigado, de que seu país é uma "democracia racial", com oportunidades iguais para todos, independentemente de sua raça ou cor da pele.

O mesmo acontece, em grande medida, em muitas organizações e instituições-chave da sociedade civil, como os partidos políticos (incluindo a esquerda), os sindicatos, as igrejas e os movimentos populares, mesmo aqueles genuinamente comprometidos com a luta pela democracia e pela justiça social. As raras vozes dissidentes, como alguns poucos intelectuais e organizações negras, permanecem circunscritas a esferas bastante limitadas. São frequentemente vistos, e algumas vezes acusados, como portadores de visões exóticas, "importadas" e certamente "não brasileiras".

\section{Bibliografia de Referência}

BANTON, Michael, Raça - Como Classificação. In CASHMORE, Ellis. Dicionário de Relações Étnicas e Raciais. São Paulo: Summus, 2000

CLAVAL Paul. Milton Santos e o pensamento radical. In.BRANDÃO Maria A. Milton Santos e o Brasil. São Paulo: Fundação Perseu Abramo, 2004

GUIMARÃES, Antonio S. A. 'Raça' e racismo e grupos de cor no Brasil. Estudos AfroAsiáticos (27): 45-63 abril de 1995

GUIMARÃES, Antonio S. A. Racismoe anti-racismo no Brasil. São Paulo: Editora34, 1999

HOBSBAWM, E.J. Nações e Nacionalismos desde 1780: programa, mito e realidade. Trad. Maria Célia Paoli e Ana Maria Qurino, 3ª ed. Paz e Terra. SP, 1990. 
LUKÁCS, Georg. Geschichte und Klassenbewusstsein. Neuwied/Berlim, Luchterhand, 1970

MILES Robert. Relações Raciais - Perspectiva 1. In CASHMORE, Ellis. Dicionário de Relações Étnicas e Raciais.São Paulo: Summus, 2000

MORAES, A. C. R de. Território e História no Brasil. São Paulo: Hucitec, 2002.

MUNANGA, K. Racismo da desigualdade à intolerância. São Paulo em Perspectiva, vol. 4, $n^{0} 2,1990$.

PIZA, Edith e BENTO, Maria A. O baile da cor - apontamentos sobre conceitos, métodos e procedimentos de classificação racial. In SILVA JR, Hédio. O Papel da Raça/Etnia nas Políticas de Promoção da Igualdade. São Paulo; CEERT, 2003

ROLNIK, Raquel. Territórios Negros Nas Cidades Brasileiras (Etnicidade e Cidade em São Paulo e no Rio de Janeiro). Estudos Afro-Asiáticos, n.17, p.29-41, 1989.

SANTOS, Carlos J. F. Nem Tudo Era Italiano: São Paulo e pobreza (1890-1915). São Paulo: Annablume, 1998

SANTOS, Milton. A Natureza do Espaço: Técnica e Tempo, Razão e Emoção. - $1^{\text {a }}$ ed. 1996, São Paulo: Edusp, 2002.

SANTOS, Milton. As Cidadanias Mutiladas. In LERNER Júlio. O Preconceito. São Paulo: Imesp, 1996/1997

SANTOS, Milton. O País distorcido: o Brasil a globalização e a cidadania. Org. Wagner Costa Ribeiro; ensaio Carlos Walter Porto Gonçalves - São Paulo: Publifolha, 2002

SEABRA, Odete C. L. Urbanização e fragmentação: apontamentos para o estudo do bairro e da memória urbana. In: Sposito, Maria Encarnação B. Urbanização e Cidades: perspectivas geográficas. Presidente Prudente, SP: Unesp/FCT, 2001.

SILVA, Denise Ferreira, Raça e Nação na Construção do Espaço Global Moderno. Ethos Brasil, n.1, p.39-48, 2002

SMITH Graham. Teoria política e geografia humana. In: GREGORY D. \& RON M. \& SMITH G. (orgs.) Geografia Humana; sociedade, espaço e ciência social. Rio de Janeiro: Jorge Zahar, 1996. 


\section{Bibliografia}

ANDERSON, Perry. Afinidades Seletivas. São Paulo: Boitempo, 2002

ANDREWS, George Reid. Negros e brancos em São Paulo, (1888-1998). Tradução:

Magda Lopes. Bauru, SP: EDUSC, 1998

APPADURAI, Arjun. Soberania sem Terrritorialidade (notas para uma geografia pósnacional). Novos Estudos CEBRAP, n.49, novembro de 1997

APPIAH, Kwame Anthony. Na Casa de Meu Pai: África na filosofia da cultura. Rio de Janeiro: Contraponto, 1997

BALAKRISHNAN, Gopal. Um Mapa da Questão Nacional. Rio de Janeiro: Contraponto, 2000

BANTON, Michael, Raça - Como Classificação in CASHMORE, Ellis. Dicionário de Relações Étnicas e Raciais. São Paulo: Summus, 2000

BOAS, Franz. A formação da antropologia americana, 1883-1911. Rio de Janeiro: Contraponto: UFRJ, 2004

BRANDÃO, Maria A. Milton Santos e o Brasil. São Paulo: Fundação Perseu Abramo, 2004

BURKE, Peter. História e teoria social. São Paulo: Unesp,2002

CARDOSO, Marcos A. O Movimento Negro em Belo Horizonte: 1978-1998. Mazza Edições, 2002

CARLOS Ana Fani A. A geografia em sala de aula. 3ª ed. - São Paulo: Contexto, 2001.

CARLOS, Ana Fani Alessandri. Geografia Brasileira, Hoje: algumas reflexões. Terra Livre, vol I, n.18, p.161-178, 2002

CASTRO Ina E. \& GOMES, P C C. \& CORRÊA R.L. Brasil: questões atuais do território. Rio de Janeiro: Bertand Brasil, 1996

CHAUI, Marilena. Brasil: mito fundador e sociedade autoritária. 5a ed. São Paulo, 
Fundação Perseu Abramo, 2004.

EDER, Klaus. A Nova política de classes.Bauru, SP: Edusc, 2002

FERNANDES Florestan. A integração do negro na sociedade de classes. São Paulo: Dominus Editora, 1965

FERNANDES, Bernado Mançano. Questão Agrária, Pesquisa e MST. São Paulo: Cortez, 2001

FINKIELKRAUT, Alain. A derrota do pensamento. Rio de Janeiro: Paz e Terra, 1988

FORBES, D. K. Uma Visão Crítica da Geografia do Subdesenvolvimento

FREYRE, Gilberto. Casa Grande \& Senzala: formação da família brasileira sob o regime da economia patriarcal. 35a ed. Rio de Janeiro: Record. 1999

GEIGER, Pedro Pinchas. As formas do espaço brasileiro. Rio de Janeiro: Jorge Zahar Editora, 2003.

GOHN, Maria da Glória. História dos Movimentos e Lutas Sociais. São Paulo; Loyola, 1995

GOHN, Maria da Glória. Teoria dos Movimentos Sociais: paradigmas clássicos e Contemporârenos. São Paulo: Loyola, 1995

GUIMARÃES, Antonio S. A. 'Raça' e racismo e grupos de cor no Brasil. Estudos AfroAsiáticos, n.27, p. 45-63, 1995

GUIMARÃES, Antonio S. A. Racismoe anti-racismo no Brasil. São Paulo: Editora34, 1999

HAESBAERT, Rogério. Territórios Alternativos. Niteroi: EDUFF; São Paulo: Contexto, 2002

IANNI, Otávio. Dialética das relações raciais. Estudos Avançados, vol. 18, n.50, p.21-30, 2004

IANNI, Otávio. O preconceito racial no Brasil: entrevista de Otávio Ianni. Estudos Avançados, vol. 18, n.50, p.6-20, 2004 
KONDER, Leandro. A questão da ideologia. São Paulo: Companhia das Letras, 2002

KOWARICK, Lucio. As lutas sociais e a cidade: São Paulo passado e presente/Clara Ant...[et al.] Rio de Janeiro; Paz e Terra, 1994

KOWARICK, Lucio. Trabalho e Vadiagem: a origem do trabalho livre no Brasil. Rio de Janeiro; Paz e Terra, 1994

LEFEBVRE, Henri. Sociologia de Marx. Rio de Janeiro - São Paulo, Forense, 1968

LEITE, José Correia. ...E disse o velho militante José Correia Leite: depoimentos e artigos. Orgorganização e textos Cuti. São Paulo: SMC, 1992

LOWY Michel. Nacionalismo e internacionalismo: da época de Marx até nossos dias. São Paulo: Xamã, 2000

LUKÁCS, Georg. Geschichte und Klassenbewusstsein. Neuwied/Berlim, Luchterhand, 1970

MALACHIAS, Rosangela. A visibilidade e vulnerabilidade da juventude negra. População Negra em Destaque CEBRAP, p.59-62, 1998

MARQUES, Eduardo. \& TORRES, Haroldo. São Paulo: segregação, pobreza e desigualdades sociais. São Paulo: Senac. 2005

MARTINS, José de Souza. O cativeiro da terra. 2a ed. São Paulo: LECH, 1981

MARTINS, José de Souza. Sociologia e Militância: entrevista de José de Souza Martins. Estudos Avançados, vol.11, n. 31 São Paulo: 1997

MARX, Karl. Contribuição à crítica da economia política. São Paulo: Martins Fontes, 1977

MILES Robert. Relações Raciais - Perspectiva 1 in CASHMORE, Ellis. Dicionário de Relações Étnicas e Raciais.São Paulo: Summus, 2000

MORAES, Antonio Carlos R. Geografia Critica: a valorização do espaço. $2^{\mathrm{a}}$ ed. Hucitec. São Paulo, 1987

MORAES, A. C. R de. Ideologias Geográficas: espaço, cultura e política no Brasil. São Paulo: Hucitec, 1988. 
MORAES, A. C. R de. Território e História no Brasil. São Paulo: Hucitec, 2002

PAIXÃO, Marcelo J. P. Desenvolvimento Humano e Relações Raciais. Rio de Janeiro: DP\&A, 2003

PINTO, Regina Pahim, Movimento negro e etnicidade. Estudos Afro-Asiáticos (19): 109120,1990

PIZA, Edith e BENTO, Maria A. O baile da cor - apontamentos sobre conceitos, métodos e procedimentos de classificação racial. In SILVA JR, Hédio. O Papel da Raça/Etnia nas Políticas de Promoção da Igualdade. São Paulo; CEERT, 2003

PRADO JR. C. Formação do Brasil Contemporâneo: colônia. São Paulo: Brasiliense; Publifolha, 2000.

QUAINI, Massimo. Marxismo e Geografia. Rio de Janeiro: Paz e Terra, 1979

RAFFESTIN, Claude. Por uma geografia do poder. São Paulo: Ática, 1993

RIBEIRO, Fernando R. Ideologia nacional, antropologia e 'questão racial'. Estudos AfroAsiáticos, n.31, p.79-89, 1997

ROLNIK, Raquel. Territórios Negros nas Cidades Brasileiras (Etnicidade e Cidade em São Paulo e no Rio de Janeiro). Estudos Afro-Asiáticos, n.17, p.29-41, 1989

SANTOS, Boaventura de Sousa. A Construção Multicultural da Igualdade e da Diferença. Palestra proferida no VII Congresso Brasileiro de Sociologia, realizado no Instituto de Filosofia e Ciências Sociais da Universidade Federal do Rio de Janeiro, de 4 a 6 de setembro de 1995

SANTOS, Boaventura de Sousa. Pela Mão de Alice: o social e o político na pósmodernidade. 8a e. São Paulo: Cortez, 2001

SANTOS, Carlos J. F. Nem Tudo Era Italiano: São Paulo e pobreza (1890-1915). São Paulo: Annablume, 1998

SANTOS, M. Sociedade e Espaço: a formação social como teoria e como método. In: Boletim Paulista de Geografia. 1977, n. 54, AGB. 
SANTOS, M. O trabalho do geógrafo no Terceiro Mundo. São Paulo: Hucitec, 1978

SANTOS, M. Por uma Geografia Nova: da crítica da Geografia a uma Geografia crítica. $1^{\text {a }}$ ed. 1978, São Paulo: $4^{\mathrm{a}}$ ed. Hucitec, 1996.

SANTOS, M. Espaço \& Método. $1^{\mathrm{a}}$ ed. 1985, São Paulo: $3^{\mathrm{a}}$ ed. Nobel, 1992.

SANTOS, M. Metamorfoses do Espaço Habitado: fundamentos teóricos e metodológicos da Geografia. São Paulo: Hucitec, 1988.

SANTOS, M. Técnica Espaço Tempo: globalização e meio técnico-científico informacional. São Paulo: Hucitec, 1994.

SANTOS, Milton. A Natureza do Espaço: Técnica e Tempo, Razão e Emoção. - $1^{\mathrm{a}}$ ed. 1996, São Paulo: Edusp, 2002a.

SANTOS, Milton. As Cidadanias Mutiladas. In LERNER Júlio. O Preconceito. São Paulo: Imesp, 1996/1997

SANTOS, Milton. O País distorcido: o Brasil a globalização e a cidadania. Org. Wagner Costa Ribeiro; ensaio Carlos Walter Porto Gonçalves - São Paulo: Publifolha, 2002b

SEYFERTH, Giralda. Os paradoxos da miscigenação: observações sobre o tema imigração e raça no Brasil. Estudos Afro-Asiáticos. n.20, p. 165-185, 1991

SEYFERT Giralda. A Colonização Alemã no Brasil; Etncidade e Conflito. In FAUSTO, Boris. FAZER a AMÉRICA. São Paulo: Edusp. 1999

SILVA, Denise Ferreira, Raça e Nação na Costrução do Espaço Global Moderno. Ethos Brasil, n.1, p.39-48, 2002

SILVA, Petronilha B. G. \& SILVÉRIO, Valter R. Educação e Ações Afirmativas: entre a injustiça simbólica e a injustiça econômica. Brasília: Inep, 2003

SKIDMORE, Thomas E. Fato e Mito: descobrindo um problema racial no Brasil. Cadernos de Pesquisa, São Paulo, n.79, p. 5-16, nov. 1991

SMITH, Neil. Contornos de uma política espacializada: veículos dos sem-teto produção de escala geográfica. In ARANTES, Antonio A. O Espaço da Diferença. Campinas, SP: Papirus, 2000 
SOJA, Edward W. Geografia Pós-modernas: a reafirmação do espaço na teoria crítica social. Rio de Janeiro: Jorge, 1993

SOUZA, Marcelo Lopes e RODRIGUES, Glauco B. Planejamento urbano e ativismo social. São Paulo: UNESP,2004

SPOSITO Maria B. E. Urbanização e Cidades: perspectivas geográficas. Presidente Prudente, SP: Unesp-FCT, 2001

SPOSITO, Eliseu S. A propósito dos paradigmas de orientações teórico-metodológicas na Geografia contemporânea. Terra Livre, vol I, n.16, p.99-112, 2001

SPOSITO, Eliseu Savério. Geografia e filosofia: contribuição para o ensino do pensamento geográfico. São Paulo: Unesp.2004

VESENTINI, José W. Geografia e Ensino: textos críticos. 8a ed. Campinas, SP: Papirus, 2005

VESENTINI, José W. O Ensino de Geografia no Século XXI. Campinas, SP: Papirus, 2004

WARE Vron. Branquitude: identidade branca e multiculturalismo. Rio de Janeiro: Garamond, 2004

WCAUANT, Loic. J. D. A underclass urbana no imaginário no imaginário social e científico norte-americano. Estudos Afro-Asiáticos (31) 37-50, 1997

ZIZEK, Slavoj. Um Mapa da Ideologia/ Theodor Adorno...[et al.] Rio de Janeiro: Contraponto, 1996 